Discussion

Papers

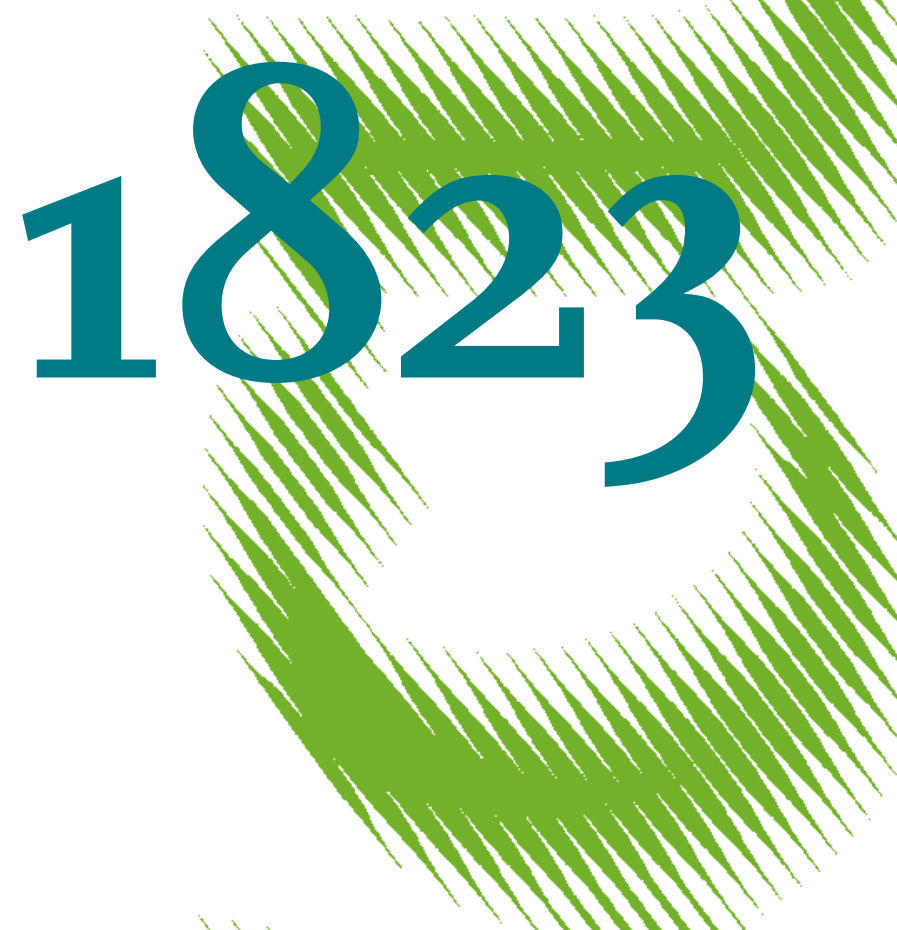

The Effect of Personalized Feedback on Small Enterprises' Finances in Uganda 
Opinions expressed in this paper are those of the author(s) and do not necessarily reflect views of the institute.

IMPRESSUM

(C) DIW Berlin, 2019

DIW Berlin

German Institute for Economic Research

Mohrenstr. 58

10117 Berlin

Tel. +49 (30) $89789-0$

Fax +49 (30) $89789-200$

http://www.diw.de

ISSN electronic edition 1619-4535

Papers can be downloaded free of charge from the DIW Berlin website:

http://www.diw.de/discussionpapers

Discussion Papers of DIW Berlin are indexed in RePEc and SSRN:

http://ideas.repec.org/s/diw/diwwpp.html

http://www.ssrn.com/link/DIW-Berlin-German-Inst-Econ-Res.html 


\title{
The Effect of Personalized Feedback on Small Enterprises' Finances in Uganda
}

\author{
Antonia Grohmann* Lukas Menkhoff ${ }^{\dagger} \quad$ Helke Seitz $^{\ddagger}$
}

October 2019

\begin{abstract}
This RCT examines the effect of a new style finance training during which participants are given personalized feedback on their financial business outcomes in addition to a "rules-ofthumb" training approach. We compare this to the effects of a "rules-of-thumb" training by itself and to a control group. Targeting about 500 small and micro entrepreneurs in Kampala, Uganda, we find that the personalized feedback training significantly improves outcomes at the six-months horizon. The index of primary outcomes increases by 0.258 SD units and overall savings improve by 0.257 SD units. Analyzing the feedbacks provided we find evidence that feedback works by increasing motivation, in line with "feedbackintervention-theory."
\end{abstract}

Keywords: Financial Training, Feedback, Small Business Growth, Economic Development. JEL codes: O12, D22, O16, L26

\footnotetext{
${ }^{*}$ Antonia Grohmann, German Institute for Economic Research (DIW Berlin), 10108 Berlin, Germany; agrohmann@diw.de.

${ }^{\dagger}$ Lukas Menkhoff, Humboldt-University Berlin; German Institute for Economic Research (DIW Berlin), 10108 Berlin, Germany; lmenkhoff@diw.de.

${ }^{\ddagger}$ Helke Seitz, German Institute for Economic Research (DIW Berlin), 10108 Berlin, Germany; hseitz@diw.de. We appreciate valuable comments from participants of the NOVAFRICA Conference on Economic Development in Africa in Lisbon, the Annual Conference "Development Economics and Policy" in Berlin, the 5th DIAL Conference on Development Economics in Paris, the Annual Conference of the German Economic Association in Leipzig, the PEGNet Conference in Bonn, and from seminars participants in Berlin, Frankfurt, Göttingen, and Hannover, in particular: Veronica Frisancho, Hannes Greve, Krisztina Kis-Katos, Friederike Lenel, Maureen Mahmood, David McKenzie, Christian Meyer, Emanuel Mönch, Patrick Puhani, Pia Raffler, Sandra Sequiera, Mattea Stein, and Susan Steiner. Financial support by the German Research Foundation (DFG) is gratefully acknowledged. This field experiment was pre-registered at the AEA RCT Registry on March 15, 2018 (ID: AEARCTR-0002785); see: https://www.socialscienceregistry.org/trials/2785.
} 


\section{Introduction}

Small entrepreneurs form a very important part of the economy in developing countries, with the majority of the work force either self-employed or working in small businesses. Despite the importance of small entrepreneurs for the economy, not only do they lack capital (e.g. De Mel et al. 2008; McKenzie and Woodruff, 2008, Banerjee and Duflo, 2014) but also the knowledge (e.g. Bloom et al., 2010; Bruhn et al., 2010, Bruhn and Zia, 2013) necessary to grow their business. Hence, there are initiatives that on the one hand, offer additional capital or seek to improve credit access and, on the other hand, provide various kinds of business trainings. While these measures often go hand in hand, we focus only on trainings.

Overall, evidence on the impact of these trainings is encouraging (McKenzie and Woodruff, 2013), as they mostly generate the desired effects to a significant extent. However, the economic sizes of these effects are often rather modest, thus raising doubts on the effectiveness of conventional business trainings. At the same time, trainings are very heterogeneous regarding their success. Ways to make trainings more successful include a "rule-of-thumb" approach (Drexler et al. 2014) and an individual counseling of entrepreneurs (Bruhn et al., 2018; Lafortune et al. 2018; Carpena et al., 2019).

Given this state of the literature, it is our aim to contribute toward an improvement in the effectiveness of financial business trainings for small enterprises. Existing research focuses on rather standard financial trainings, which are cost-effective as the same content is delivered to a large number of participant. In contrast, individual counseling, i.e. financial advice to entrepreneurs according to their specific needs, shows larger economic effects (Bruhn et al. 2018; Lafortune et al., 2018). Unfortunately, individual counseling is relatively costly. With this in mind, we develop a new form of training and analyze whether this training, which combines a (cost-effective) standard training curriculum with individualized aspects of counseling can lead to increased effectiveness. Hence, we include individualized elements in form of feedback, which are specific to each entrepreneur, into a finance training and call this training form "personalized feedback."

In this study, we embed personalized feedback into a standard finance training for small entrepreneurs and examine its effectiveness compared to a pure finance training. Providing feedback, i.e. information regarding aspects of an individual's performance, is known to foster 
learning processes and to contribute to changes in behavior, as shown, for example, in the areas of energy conservation (Karlin et al. 2015), problem drinking (Riper et al., 2009) and curbside recycling (Schultz, 1999). To understand how feedback translates to changes in behavior, we draw on "feedback intervention theory" (Kluger and DeNisi, 1996). The theory's main argument is that behavior is regulated by comparisons of feedback to goals or standards, and hence, the identification of gaps between both (Kluger and DeNisi, 1998). In turn, these detected discrepancies increase motivation to reduce perceived gaps. Furthermore, there is evidence that larger discrepancies lead to stronger changes in behavior, as shown by Kluger et al. (1994) and Schultz (1999).

To give an example, finance trainings typically have a module where entrepreneurs are informed about the usefulness of savings for buffering shocks and building capital. Related to this, entrepreneurs state their investment plans and the respective capital they need to save, which leads to savings goals. As part of the feedback, we inform respondents about their past savings performance. Specifically, we inform respondents about the difference between how much they stated they needed to save during the baseline survey and how much they have actually saved at the six-month follow-up. This generates a discrepancy for each individual regarding her desired and actual savings amount. According to feedback intervention theory, explicitly informing individuals about their performance and revealing potential gaps fosters motivation and may strengthen efforts to change behavior. In the case of savings goals we can directly test whether awareness of larger discrepancies leads to increased savings.

In order to assess the effects of providing feedback, in addition to finance training, we conduct a randomized controlled trial (RCT) in the capital city of Uganda, Kampala. The sample is divided into three groups: one group receives a finance training only, the second treatment group receives the finance training plus personalized feedback (henceforth feedback training), and the third group is the control group. To rule out that effects in the treatment groups may be driven by contact and time spent with our training staff, the control group receives health training that is unrelated to the content of the finance training.

Our randomized controlled trial is implemented based on an existing panel of around 500 micro and small enterprises. Thus we can use the existing regular panel waves and the past business performance, to have useful information about potential training participants. Our 
resource limitations allow for roughly a half hour training of each entrepreneur. The treatment consists of information in the form of a presentation that takes an average of 28 minutes and 32 minutes, for the finance and the feedback training, respectively; i.e. the feedback training is just 4 minutes longer on average. Given the sample size and the limited training input, it is unlikely that we obtain significant results with a conventional training form. Our minimum detectable effect size is 0.2667 under usual assumptions and, thus, high compared to an average effect size of financial education on financial behavior of below 0.1 SD units (Kaiser and Menkhoff, 2017) or an effect size of training programs on business practices between 0.1-0.2 SD units McKenzie and Woodruff, 2013). Therefore, we aim for trainings with high expected effect size. Thus, our finance training is based on lessons learned from the "rule-of-thumb" approach, as introduced by Drexler et al. (2014). This training delivers the content in an easy and understandable way and shows relatively high effectiveness. In our study, the feedback training group receives the finance training of the other treatment plus an add-on, i.e. additionally provides feedback information about the situation of the entrepreneur and their small business.

We find that both trainings seem to generate desired changes in behavior, although effects of the conventional finance training are never statistically significant. The strongest effect of the feedback training is on the index of savings behavior with a highly significant effect size of 0.257 SDs; in this area, feedback training is more effective than the finance training. The feedback training also has a marginally significant effect on investment behavior. Finally, when we build an index covering the four main outcome areas of the training (investments, savings, profits, and loans), feedback training again has a significant effect. Regarding potential mechanisms of the feedback training, we exploit discrepancies induced by the feedback information. Discrepancies are reflected by the estimated time it will take respondents to reach their savings goal and show differential effects: they increase formal savings more if they are further away from their savings goal than if they are close, as predicted by feedback intervention theory (Kluger and DeNisi, 1996).

While these described effects hold for a survey conducted six months after the intervention, effect sizes are much lower in the end-line survey 12 months after the training and coefficients are no longer statistically significant. This indicates that feedback should be regularly and repeatedly provided in order to reinforce and improve the long-term effectiveness of the personalized 
feedback training (Schultz, 1999).

This paper is embedded in a larger literature examining small businesses trainings. Many of these trainings focus on financial concepts, as in this paper. Typically, they succeed, but the degree of success differs and there seems to be room for improvement. Several classroom training interventions find effects on business knowledge or business practices, but with muted or no effects on key business performance measures like revenues or profits (Bjorvatn and Tungodden, 2010, Karlan and Valdivia, 2011; Bruhn and Zia, 2013, Gine and Mansuri, 2014). Classroom trainings are the most common way to provide information. The training content is standardized and not adjusted to the particularities of specific firms. Interventions that take into account individual challenges of firms are those providing counseling services, where the content is tailored to the businesses' needs. Lafortune et al. (2018) randomly provide personalized counseling sessions to microentrepreneurs in Chile and find significant increases in household income. Another promising counseling intervention is conducted among Mexican enterprises by Bruhn et al. (2018). They find effects on productivity in the short run and employment in the long run.

Our innovation is to combine a rule-of-thumb finance training approach with a personalized feedback and evidence from both strands of the literature suggests that this may be a promising way to proceed (Drexler et al., 2014; Bruhn et al., 2018, Lafortune et al., 2018; Carpena et al., 2019). However, this requires that information about the treatment groups is available or will be collected in advance. Moreover, cost issues may play a role as the preparation of personalized feedback needs more effort than standard classroom trainings.

This paper is structured into six further sections: Section 2 describes the experimental setting and Section 3 the data. Results are presented in Section 4, while Section 5 explores the underlying mechanism of the effectiveness of feedback. The sensitivity of our estimation results is probed in Section 6 and Section 7 concludes.

\section{Experimental Setting}

In this section we describe the implementation of our intervention, which consists of three treatment arms (Section 2.1) and our empirical strategy (Section 2.2). 


\subsection{Experimental Design}

To foster financial knowledge among micro and small enterprises, we develop a finance training. This training covers: (i) business investments; (ii) savings; (iii) profits; (iv) business loans to finance investments; and (v) related minor topics, in particular separating household and business finances. A detailed curriculum of the content of each topic is shown in column (2) in Appendix Table A.1. Regarding the design and delivery method of the finance training, we build on findings by Drexler et al. (2014). They provide evidence that trainings focusing on ease of understanding by providing simple rules of financial decision making ("rule-of-thumbs") perform better than trainings focusing on the comprehensiveness of the material. Hence, we develop a training that is simple in its concepts and easy to understand. The training content is delivered in a compact way without delivering too many details or extensive exercises. Each content is summarized and depicted with easily memorized statements, framed as simple heuristics or routines for financial decision making. To ensure that the content of our training is in line with the national financial inclusion strategy, our rule-of-thumbs are in accordance with the core messages regarding financial literacy by the Bank of Uganda (Central Bank)!

The other treatment group receives personalized feedback in addition to the finance training. This additional component crucially marks the difference between both treatment groups. This treatment group receives feedback regarding the past financial performance of the business and the business owner's financial behavior. This feedback adds a personalized, i.e. an individualspecific, component to the training and, hence, bears similarities to individual counseling. To illustrate the trainings: while as part of the first treatment arm the finance training highlights the importance of having a savings goal and starting to save toward that goal (depicted as ruleof-thumb messages); the second treatment arm additionally provides feedback about whether the business owner actually has a savings goal and, if so, how much the business owner has already saved toward it. The individual feedback information is derived from the baseline survey. Hence, whenever our data allow, the second treatment group receives personalized feedback that is directly related to a rule-of-thumb message that was delivered as part of the finance training.

The control group receives health and safety information over a comparable length of time to avoid estimation bias from Hawthorne-type effects. The information provided for the finance

\footnotetext{
${ }^{1}$ See: https://www.bou.or.ug/opencms/bou/bou-downloads/Financial_Inclusion/Core-Messages-FinancialLiteracy_August-2013.pdf, last checked on August 17th, 2018.
} 
training, the personalized feedback, and the control group is delivered and taught in face-to-face sessions by university educated and experienced local instructors. Prior to treatment implementation, the instructors completed an intensive five-day training and an additional two-day pilot. The instructor and respondent then met at the site of the respondent's business. During this meeting, the training content is delivered using a presentation on tablet PCs. After the presentation, each respondent receives a booklet that includes detailed descriptions of the content that was presented. The booklet also includes the rule-of-thumb messages and, additionally, if applicable, personalized feedback information. To encourage respondents to actively listen to the presentation and to foster interaction between instructor and respondent, we use several pedagogical tools, such as (very short) individual exercises, and include pictures and figures to illustrate concepts. The individual exercises include reflections about business investments and household budget. These reflections are noted in the booklet. Another exercise is a discussion on the advantages and disadvantages of savings and borrowing for investments. To ensure that all respondents could follow the contents of the training, the presentation and booklet are either in English or Luganda (the local native language) depending on the preferences and skills of the business owner. The presentation of all types of trainings takes between 20 and 32 minutes..$^{2}$ The training duration does not significantly differ between both treatment groups at any conventional significance level.

Our intervention was implemented in October 2017. Prior to implementation, we piloted all three trainings at a local market in July 2017 in Kampala. Baseline information was collected among 500 MSEs in September of the same year. Of these, 166 were assigned to the finance training, 165 to receive the additional feedback and 169 to the control group. The intervention was implemented during another round of business visits soon after the baseline survey. The midline data was collected six months after treatment implementation (April 2018), and the end-line another six months later (i.e. 12 months after the trainings, in October 2018). Power calculations show that significant treatment effects cannot be expected in this setting from conventional training approaches, which realize effect sizes on the order of 0.1 SD units Kaiser and Menkhoff, 2017) and up to 0.2 (McKenzie and Woodruff, 2013). Our experiment has 80 percent power to precisely detect (at $\alpha=0.05$ ) effect sizes as small as 0.2667 standard deviation

\footnotetext{
${ }^{2}$ On average, 20 minutes are spent to deliver information to the control group, 28 minutes are spent for the finance training, and 32 minutes for the finance training plus feedback group.
} 
(SD) units.

Attrition in our sample due to refusals, closed businesses, or change of business sectors is fairly low. Six months after the baseline survey, we follow up with 460 respondents (i.e. the attrition rate is 8 percent); due to increased tracking efforts, the attrition rate 12 months later is even lower: 7.6 percent. To test whether attrition is different between our treatment arms, we regress a binary attrition variable on both treatment indicators. In the short-run, attrition is not different between the treatment groups; however, in the long-run, firms in the control group are slightly more likely to drop out than those in the finance group (see Table A.2).

\subsection{Empirical Strategy}

We estimate causal treatment effects by comparing both treatment groups (finance training and feedback training) to our control group. The relationship between both trainings and the outcome measures is estimated using an analysis of covariance (ANCOVA) estimation (McKenzie, 2012). As entrepreneurs are randomly assigned to one of the treatments, we estimate the following equation to get unbiased estimates:

$$
\begin{aligned}
& y_{i, t}=\alpha+\beta_{1} \text { Finance } \text { Training }_{i, t}+\beta_{2} \text { Feedback Training }_{i, t} \\
& +\theta y_{i(t-1)}+X_{i}^{\prime} \gamma+\epsilon_{i, t}
\end{aligned}
$$

where $y_{i, t}$ is the outcome variable, Finance Training $_{i, t}$ indicates being assigned to the first treatment group, Feedback Training $_{i, t}$ is an indicator for being assigned to the group that receives feedback in addition to the finance training, $y_{i(t-1)}$ is the pre-treatment measure of the outcome variable and $X_{i}$ is a vector with controls for industry strata as suggested by Bruhn and McKenzie (2009). The parameters $\beta_{1}$ and $\beta_{2}$ give the "intention-to-treat (ITT)" effect, which is the effect of being assigned to one of the trainings. In case $y_{i, t}$ is binary, we estimate a linear probability model. While individuals in all treatment arms are free to participate in the information intervention that was part of a short survey, the non-compliance rate in our setting is very low. This is potentially driven by the small financial incentive that was offered to participants as a token of appreciation for their time. In addition, the intervention was conducted shortly after the baseline survey, which might have strengthened trust in our research team. The few non-compliers ( 2 percent) either refused to participate, could not be 
tracked, or were not available. Hence, due to the low non-compliance rate, our estimated ITT effect is of similar magnitude as the "treatment-on-the-treated (TOT)" effect.

In our analysis, we are interested if the overall effectiveness of each training on a family of different outcomes is significantly different from zero (see Duflo et al. (2007)). Therefore, we aggregate variables belonging to one family of outcomes to a standardized index following Kling et al. (2007). The index $\mathrm{z}$ is the average of all $\mathrm{i}=1, \ldots, \mathrm{I}$ standardized variables belonging to a family of outcomes. Specifically, $z=\frac{1}{I} \sum_{i=1}^{I} z_{i}^{*}$ where $z_{i}^{*}=\frac{y_{i}-\mu_{i}}{\sigma_{i}}, y_{i}$ is an outcome variable, while $\mu_{i}$ and $\sigma_{i}$ are the mean and standard deviation of the respective outcome variable of the control group. In addition to the general impact of our different treatments (as captured by the indices), we are also interested in the intention-to-treat effect on individual outcomes. Consequentially, we test multiple hypotheses simultaneously, which might raise concerns as the probability of a false rejection may be higher than the usual significance level $\alpha$. Therefore, we not only work with unadjusted p-values, but we also report family-wise adjusted p-values based on Westfall et al. (1993) $!^{3}$

\section{Data}

This section describes the sampling process of our study and the major differences between the different industry sectors represented in the sample (Section 3.1), the outcome variables (Section 3.2), and baseline descriptive statistics (Section 3.3).

\subsection{Sample}

Our intervention is conducted among a panel of micro and small enterprises (MSEs) in Kampala, Uganda. As part of the sampling process, 220 administrative areas (zones) with predominant business activity were identified based on interviews with the local administration. Subsequently, 21 zones were randomly selected for door-to-door screening. The sample is stratified with respect to the three main industry sectors: retail, manufacturing, and services, but also includes some entrepreneurs who have changed their sector of activity over time. These three

\footnotetext{
${ }^{3}$ Family-wise adjusted error rates following Westfall et al. (1993) are applied in the financial education literature for example by Calderone et al. (2018).
} 
industry sectors have quite distinctive characteristics 4 Table 1 shows descriptive differences between the industry sectors at the baseline in 2017 .

\section{[INSERT TABle 1 about here]}

The share of female owned enterprises is highest in the services sector (62 percent). This is not surprising, as most of these businesses operate in the field of hairdressing and beauty which are mostly owned by women. The sectors are also quite heterogeneous with respect to the educational level of the entrepreneur. While the overall share of entrepreneurs with higher education (upper secondary degree (A-level) or higher) is 34 percent in the overall sample, it is lowest among businesses in the services sector (22 percent). The average capital stock is highest in the manufacturing sector, where investments in machines represent the lion's share of total capital stock. In the retail industry, the average amount in inventory is comparatively high (whereby the stock in finished goods is larger than the stock in raw materials). In line with high levels of capital stock and inventory in these two industry groups, the number of sales in both groups outnumbers the sales of the services sector by far.

\subsection{Outcome Variables}

In the following analysis, we present treatment effects on four families of primary outcomes, as defined in the pre-analysis plan. These outcomes are related to investments, savings, profits, and loans, with each outcome family consisting of several variables.

The investment related outcomes include the following variables: whether the respondent has acquired any new physical capital, the total number of physical capital items purchased and its total value at purchasing prices since the last interview wave, which is six months for each follow-up wave. Physical capital comprises capital invested in tools, machines, furniture, or other items that are used in the business or production process. Finally, we use the amount of the current stock of inventory, which is the sum of raw materials and finished goods at the time of the survey interview.

Regarding the index on savings, we use an indicator whether someone has any savings and the total amount of savings held either in formal savings (held in bank accounts or with savings

\footnotetext{
${ }^{4}$ Throughout the years of the panel survey, some businesses (17) started operating in industry sectors that are different from manufacturing, retail, or services sector. The sector of these businesses is summarized by the term "Remaining Sectors."
} 
and credit cooperatives (SACCOs)) or informal savings (held with a rotating savings and credit association (ROSCA), money collectors, at home, with friends and neighbors, or in a mobile money account) $!^{5}$ Lastly, we use whether someone specifies a concrete savings goal as savings related outcome.

We consider several variables related to the profit of the firm. First, we take a survey question that directly asks for the firms' profit in the last four weeks, as suggested by De Mel et al. (2009). In addition, we calculate the value added as revenues minus costs. For the calculation of value added, we directly ask the entrepreneur for their total revenues (sales) and costs over the last month.

Lastly, we use two kinds of information about loans to capture the training-related borrowing behavior of entrepreneurs. The training does not just inform about the role of loans to increase business performance but also discusses the inherent risks of loans if they do not generate enough profitable business to cover all loan-related costs. Ideally, one would need detailed information about new loans and their consequences, which we do not have available. Thus, we use information whether entrepreneurs applied for a business loan and the loan amount, but we are aware that more loans are not necessarily the desired outcome of the training over shorter-term horizons.

In addition to these primary outcome families, the pre-analysis plan states a list of secondary outcomes: i.e. measures of financial literacy, financial awareness, financial attitudes and perceptions, financial planning, financial reflection, as well as separating household and business finances. As the training is short and does not focus on all of these issues explicitly (for example, there is no direct training on financial literacy), it may be expected that there are no or small effects to be reported on these secondary outcomes. Results about potential treatment effects on these variables are provided in Appendix Table B.1, a definition of all variables can be found in Appendix Table B.2.

\footnotetext{
${ }^{5}$ Mobile money services are operated in Uganda by phone companies and, thus, not classified as part of the formal financial sector; however, their savings component is so small that classifying them as formal savings does not change any result qualitatively.
} 


\subsection{Descriptive Statistics}

Table 2 provides pre-intervention characteristics of the baseline survey by treatment status along with p-values for differences between the control group and each of the treatment groups (columns (5) and (7)).6 As the entrepreneurs are randomly assigned to each group, we expect them to be similar at baseline. Regarding entrepreneurial characteristics (Panel A), there are no significant differences between the groups. Unfortunately, regarding our main primary outcome indices, two imbalances between the control group and the group assigned to the finance trainings exist. As imbalances can occur by chance, we additionally test for joint orthogonality of the estimated parameters. We do this by running separate linear regressions for each treatment assignment indicator (versus the control group) on entrepreneurial characteristics and primary outcome indices. The corresponding F-statistics are presented in the last row of Table 2 and indicate that the null hypothesis, i.e. all coefficients are jointly equal to zero, cannot be rejected. Thus, the finance training group and the control group are not generally different from each other.

\section{[INSERT TABle 2 ABOUt HeRE]}

Panel (A) provides the socio-economic background characteristics of the entrepreneurs in our sample. The table shows that respondents are, on average, 38 years old; share a household with 4 other persons; 41 percent of the businesses are run by a women; 34 percent have higher education, meaning they have a upper secondary school degree (A-level) or higher; and 50 percent of the cases do not have employees as own-account workers.

The average business operates with invested physical capital of 5,827,000 UGX, i.e. 1,579 USD. $7^{7}$ This capital is invested in machines, tools, furniture, or other equipment used in production.

As shown in Panel B in Table 2 (and mentioned above), the saving index of the finance group at baseline is significantly higher than for the control and the opposite relation holds for the loan index. We show in the robustness analysis in Section 6 which variables cause this imbalance and that all ANCOVA estimations taking into account these imbalances confirm earlier findings.

\footnotetext{
${ }^{6}$ All secondary outcomes are balanced at baseline. This is shown in Appendix Table B.3.

${ }^{7}$ To account for enumeration errors, financial outcomes used in our analysis are winsorized at the $99^{\text {th }}$ percentile, see Blattman et al. (2014); Karlan et al. (2015); Campos et al. (2017); Bruhn et al. (2018) who apply the same approach.
} 


\section{Results}

This section describes the causal treatment effects on our four families of outcome variables. While Section 4.1 summarizes the short- and long-term effects on aggregated outcomes measured as indices, Section 4.2 sheds light on the effect of the single components belonging to each outcome family, and Section 4.3 analyzes the effectiveness of the intervention for various subsamples. Section 4.4 examines costs of this intervention.

\subsection{Main Treatment Effects}

We begin by describing the short-term (six-month follow-up) effects of the finance and feedback training on primary business outcomes. The reported results, i.e. average intent-to-treat (ITT) effects and respective standard errors are reported in Table 3, Panel A, for all four families of business outcomes: investment, savings, profit, and loans. While results on these outcomes are shown in columns (1) to (4), column (5) shows the result on an "overall index," which comprises all four primary outcome indices. The presented coefficients can be interpreted as the standardized mean difference of each assigned treatment group compared to the control group. For example, the finance training increases the investment index by 0.118 standard deviation units of the control group.

\section{[INSERT TABLE 3 ABOUt HeRE]}

Overall, we find that almost all coefficients for both types of trainings are positive six months after intervention, indicating that business outcomes develop in the intended direction due to the training intervention. The only exception is the estimated effect on the loan index, whereby a negative effect here does not necessarily indicate a failure of the training as argued above. Beyond the expected coefficient signs, we find that their sizes are indeed quite large; this may be somewhat unexpected given the short training intervention of about half an hour but could be the result of training face-to-face.

Given the aforementioned limited statistical power of our study, we form an index of all four indices, i.e. an overall index, to test whether the treatments have an effect overall: indeed, this is the case. The effect size of the feedback training is $0.258 \mathrm{SD}$ units and highly significant, while the effect of the finance training only is also sizeable at $0.07 \mathrm{SD}$ units. To probe these 
estimates, we conduct a robustness analysis with regard to the construction of the overall index, which confirms our finding (see Section 6).

Turning to the two outcome families with very encouraging results, we find a significant effect of the feedback training on the saving and the investment index. The ITT effect on the savings index is large at 0.257 , i.e. more than a quarter of a standard deviation for the control group. Here, we are also able to detect a significant differential effect between both treatment groups (p-value of 0.07), hence: receiving the feedback training increases the savings index more than receiving the finance training only. For the investment index, the estimated marginally significant effect is $0.197 \mathrm{SD}$ units. The remaining estimated coefficients range between 0.021 and 0.233 SD units. As the estimated minimum detectable effect (MDE) size is 0.26 , we cannot rule out a non-zero effect of the trainings on these indices. When we turn to the loan index, estimated coefficients are negative and insignificant. While this may look as if entrepreneurs do not plan to expand their business, which might be disappointing in general, the training focuses not on loan expansion but on the proper use of business loans, in particular on ensuring repayment capacity; these qualitative issues cannot easily be addressed in our data. Thus, we also calculate an "adjusted overall index" covering three indices (investment, savings and profit), which is slightly higher than the overall index based on four indices with 0.1 for the finance training and 0.325 for the feedback training.

While analyzing the short-term effects shows encouraging results, effects become much smaller 12 months after the intervention. The 12-month follow-up results, provided in Panel B, show that effect sizes are almost always smaller than after six months and that the respective coefficients are consistently insignificant. The adjusted overall index for the finance training decreases from 0.1 to -0.015 , comparing 6 to 12 months, the indices for the feedback training decrease from 0.325 to 0.066 . Overall, neither the finance training nor the feedback training are able to persistently improve behavior of the addressed entrepreneurs. 8 We also test the effec-

\footnotetext{
${ }^{8}$ Appendix Table A.3 provides different specifications of the estimation of long- and short-term intention-to-treat effects. For reasons of comparison, Panel A and B of Appendix Table A.3 report the round-by-round short-and longterm results as already reported in the main result Table 3 . Note that in Panel B of Table 3 , we control for another intervention that was cross-randomized six months later in April 2018 on top of the existing one conducted in October 2017. The estimation provided in Panel C of Appendix Table A.3. includes the interaction between both treatments. As can be seen, there are no complementarities between both treatments, hence, in our preferred long-term specification we analyze effects by simply controlling for the second intervention conducted in April 2018. In addition to round-by-round treatment effects, we also provide average effects across rounds where we pool both follow-up rounds (this approach is also used by (De Mel et al. 2014, Karlan et al., 2015). Results are provided in Panel D and E (with additionally interacted treatments).
} 
tiveness of our intervention on secondary outcomes. As mentioned in the introduction, these outcomes get less or even no attention in the trainings and accordingly the effects are small and insignificant throughout (see Appendix Table B.1).

\subsection{Treatment Effects on Single Components}

In this section, we present the causal effect of each training on the components that belong to one family of primary outcome measures. As we do not find effects in the long run, we provide estimated effects on single components in the short run only. In the order of presentation from above, we start with the effects on investment variables.

Investment. The investment index is made up of four variables, i.e. the decision to purchase physical capital, the associated total amount invested in physical capital, the number of investments, and finally the inventory amount. In the six months since the last survey wave, 57 percent of the control group invested in physical capital; for those assigned to one of the treatment groups, the percentage is $2-4$ points higher (see Table 4 , column 2). This effect is not significant. While investment amounts also do not change to a statistically significant degree, these latter effects seem to be economically important: the feedback training leads to 28 percent greater physical capital, whereas the respective number for the finance training is close to zero. While the increase in the investment amount of both treatment groups is insignificant, we find that the feedback training leads to a significantly larger number of investments. Lastly, regarding the stock of inventory, the estimated coefficient is insignificant, but again the economic effects are non-negligible with 29 percent for the feedback training and 28 for the finance training respectively.

\section{[INSERT TABle 4 ABOUt HeRE]}

Savings. The effects on the components belonging to the savings index are reported in Table 5. We find no evidence that any of the trainings changes the extensive margin, meaning the number of business owners who save (column (2)). However, we find that the assignment to both trainings increases the savings amount at formal financial institutions to an economically sizeable degree (although statistically insignificant), i.e. 29 (28) percent for the finance (feedback) training group. Moreover, we find a significant effect of the feedback training on informal 
savings (column (4)): Participants in the feedback training increase their informal savings by 162,000 UGX (44 USD), which is an increase of around 64 percent. This effect is significantly larger for the feedback than for the finance training. Lastly, we show that our interventions have either no or small effects on formulating specific savings goals.

\section{[INSERT TABLE 5 ABOUT HERE]}

Profits. Next, we look at profits and their components. Table 6 shows that the feedback training, tentatively, has positive effects on profits, value added, sales and costs. However, only the effect on sales, is significant. While the average sales of the control group are 4,638,000 UGX (1,256 USD), the average sales of the feedback training group are 46 percent larger. As the average treatment effect of the finance training group on sales is slightly negative, this leads to a significant difference between the effects of both treatment groups. Overall, the finance training does not have much impact on the profit variables; in contrast, the overall index regarding the feedback training indicates that it may have an impact but the coefficient is not statistically significant.

\section{[INSERT TABle 6 about HeRE]}

Business Loans. Table 7 shows the effect of both trainings on two items related to business loans. The first outcome variable is whether the participant applied for a business, hence productive, loan. The second variable is the business loan amount. We find no significant effects on these loan-related variables.

\section{[INSERT TABLE 7 ABOUT HERE]}

\subsection{Heterogeneity}

We further analyze heterogeneity in treatment effects with respect to gender, industry sector, educational level, and financial literacy level. We find additional beneficial effects for men when participating in the feedback training regarding savings outcomes. This finding is provided in Table 8 .

[INSERT TABLE 8 ABOUT HERE] 
To rule out that other factors correlated with gender are driving this beneficial effect for men, we re-estimate our model by controlling for variables with baseline differences between men and women. We control for levels of profit, sales, industry sector, education, whether the respondent is an own-account worker, number of employees, capital stock, formal savings, and whether the respondent feels pressure to share extra income. Additionally, we interact these variables with treatment assignment. Appendix Tables A.4 and A.5 show that irrespective of controlling for pre-intervention differences, men benefit from the feedback training. This finding is in line with other research that finds training benefits for men, but lack evidence for women Gine and Mansuri, 2014, Berge et al., 2015). 9 H However, regarding the three other characteristics, we find no clear evidence for heterogeneous treatment effects wit respect to education (Table A.6), financial literacy level (Table A.7), and industry (Table A.8).

\subsection{Costs}

While the feedback training is relatively successful, at least at the 6-months horizon, it is also obviously more costly than a rather conventional finance training. Thus, in this section, we show calculations in order to obtain an impression about absolute and relative costs, if one would think about a roll-out of such a program. We divide costs into fixed costs related to the development of the training and variable costs per entrepreneur being treated. Again, these costs depend on the specific circumstances, so we can only provide a rough estimation.

We calculate the fixed costs for the development of the finance training to be about 7,700\$ and, additionally, about $830 \$$ for the feedback module only. These costs cover the direct development of the trainings including further preparatory measures. They do not cover costs that occur in the process toward creating the specific trainings.

The variable costs for the treatments include the following: training of the enumerators, their time during training and in the field (i.e. salary), their further direct costs (such as transport, airtime, allowance, etc.), the same kind of costs for supervisors, costs for materials (such as printing the brochures), and finally a small financial reward to participants. The total variable costs are about 4,400\$ for 500 training participants (as the control group also receives some training), i.e. about $8.80 \$$ per participant. There is an additional cost for implementing the

\footnotetext{
${ }^{9}$ Regarding the literature that focuses on alleviating constraints of microenterprises, similarly beneficial effects for men are found when financial constraints are addressed by providing grants (De Mel et al., 2008, 2012).
} 
feedback information: while the process of including information about participants' financial behavior in the brochure can be automated in our setting, there is still some extra cost as manual corrections occur. These are calculated as about $4.5 \$$ per participant, and are complemented by survey time related costs of the 4 extra minutes which may lead to another half US-dollar, i.e. overall $5 \$$.

The total costs of the trainings covered here obviously depend on the circumstances and the number of individuals treated, as the latter leads to a distribution of fixed costs. In our case, the baseline information, including the necessary information about earlier financial behavior, is assumed to be given. Moreover, the field experiment is in a city, i.e. with limited transport time and costs. Finally, given the number of treated, allocating fixed costs to participants of the finance and the feedback training leads total unit costs of $29.70 \$$ for the finance and $35.60 \$$ for the feedback training.

However, taking into account a potential roll-out of the intervention would reduce the per unit costs due to larger treatment groups. Assuming a sample size of 1,000 per treatment arm would translate to changed per unit costs of the finance training of $12.20 \$$ and $13.50 \$$ for the feedback training. In comparison to other interventions providing financial education trainings, our costs are rather low: Cole et al. (2011) estimate costs of $17 \$$ for 274 participants invited to receive a financial literacy training, Calderone et al. (2018) report $28 \$$ for a two-day training. In a study that also targets microenterprises, counseling costs amount to $75 \$$ per hour and the intervention provided in total 10 hours of counseling (Karlan et al., 2015).

\section{Why is the Provision of Feedback Effective?}

Our results show that providing feedback in addition to a finance training has encouraging effects on several crucial business outcomes. Most promising is the statistical increase of the saving index by $0.257 \mathrm{SD}$ units. In contrast, the effect size of the pure finance training is only $0.021 \mathrm{SD}$ units and thus $8 \%$ of the feedback training effect. In this section, we analyze a concrete mechanism that can (partially) explain the observed changes in behavior, according to feedback intervention theory ${ }^{10}$

\footnotetext{
${ }^{10}$ This section is of an explorative nature and was not part of our pre-analysis plan.
} 


\subsection{Underlying Mechanism of Providing Feedback}

Feedback intervention theory (FIT) generally relates the provision of feedback to changes in individual behavior (Kluger and DeNisi, 1996). Feedback in this context is information regarding business performance of the individual (Hattie and Timperley, 2007). According to FIT, behavior is regulated by comparisons between a standard or a goal and the feedback, which result in a discrepancy. This perceived discrepancy is a vital source for the motivation and to move toward the standard. In the following, we link feedback intervention theory to changes in individuals' savings behavior. Specifically, we provide feedback to individuals regarding their desired and their actual savings goal amount. Each individual's desired savings goal amount serves as an equivalent to a standard in FIT theory. We are interested in examining whether providing feedback about their savings progress or, more specifically, the resulting gap indeed motivates people to change behavior as postulated by FIT. To investigate this and to distinguish between effects from the finance and the feedback training, we interact the resulting behavior gap with an indicator for assignment to each treatment arm. Thus, we estimate the following specification:

$$
\begin{aligned}
& y_{i, t}=\alpha+\beta_{1} \text { Finance } \text { Training }_{i, t}+\beta_{2} \text { Feedback Training }{ }_{i, t} \\
& +\beta_{3} \text { Finance Training }{ }^{*} \text { Gap }_{i, t}+\beta_{4} \text { Feedback Training }{ }^{*} \text { Gap }_{i, t} \\
& +\beta_{5} \operatorname{Gap}_{i, t}+\theta y_{i(t-1)}+X_{i}^{\prime} \gamma+\epsilon_{i, t}
\end{aligned}
$$

The variable Gap measures the discrepancy between the desired savings goal amount and the actual savings amount for each individual. The variable Gap is measured in months, reflecting the remaining time the individual has to keep on saving in order to reach their desired savings goal. This calculation is based on the monthly savings behavior of each individual at baseline. The crucial difference between the treatment groups, however, is in revealing this gap. Whereas the gap is revealed as feedback information to individuals assigned to the feedback training, it is not to individuals assigned to the finance training. We are particularly interested in the parameter $\beta_{4}$ of the equation above. $\beta_{4}$ indicates how the revealed gap, communicated as part of the feedback training, affects $y_{i, t}$, in particular savings outcomes. In contrast, the parameter $\beta_{3}$ serves as counterfactual, as individuals receiving the finance training are not informed about their individual discrepancy. Hence, if feedback training enhances individuals' behavior due 
to an increased discrepancy as postulated by FIT, this would be reflected by a positive and significant parameter $\beta_{4}$. In addition, we provide p-values for a test on the equivalence of $\beta_{3}$ and $\beta_{4}$.

\subsection{Evaluation of Providing Feedback about Savings Goals}

In the following, we empirically analyze if providing feedback, which results in a discrepancy, enhances individuals' motivation and consequently improves savings outcomes. The discrepancy analyzed is the mismatch between an individual's desired savings and actual savings goal amount. The estimation results based on Equation 2 are provided in Table 9,11

\section{[INSERT TABle 9 ABOUt HeRE]}

We begin by interpreting the estimated coefficient of the variable "Gap (in months)" $\left(\beta_{5}\right)$. The almost consistent negative coefficient on each outcome variable reflects that the further away individuals are from reaching their savings goal, i.e. the larger the discrepancy is, the lower are the associated savings outcomes. However, the marginal effect of this discrepancy cannot be seen in isolation as assignment to treatment matters. Those individuals assigned to the feedback training have an additional positive effect. In sum, the marginal effect of the gap on the saving index and formal savings turns positive for those who receive the feedback training. This is in line with feedback intervention theory, following the theory's argumentation, an increasing gap between a feedback and a standard can have a motivational effect for the individual.

Regarding heterogeneous effects by gender, for the saving index variable we find that men respond significantly to the discrepancy communicated by the feedback (see Table 10). This could be one potential channel that explains, why the feedback training is more beneficial for men with regard to savings outcomes. However, this is not found for the female subsample. Regarding effects by levels of education, financial literacy, and industry there is no conclusive evidence that certain subgroups respond specifically strong to the communicated gap (analyses result are provided in Table A.9 and Table A.10).

\section{[INSERT TABLE 10 ABOUT HERE]}

\footnotetext{
${ }^{11}$ The number of observations in this panel is slightly lower as this analysis is restricted to business owners who specify a concrete savings goal.
} 


\section{Robustness Analysis}

We conduct a number of robustness checks to assess the sensitivity of our results to the measurement of the overall index, to the inclusion of unbalanced variables at baseline and potential spillover effects.

Overall Index. Here we summarize the findings of a robustness analysis on the overall index as presented in Table 3, column (5). The alternative overall indices are found in Appendix Table A.11. For better comparison, column (1) shows again the overall index (from Table 3, column (5)). In column (2), we provide an alternative overall index that is the average index over all 14 (standardized) single variables that are part of the four primary outcome indices as presented in Table 3 , columns (1)-(4). Compared to the overall index, the effect of the feedback training is slightly larger in magnitude but still similar. The effect of the finance training, however, reduces slightly in magnitude. Both average indices in columns (1) and (2) simply weight each component of the index equally. An alternative option is to assign weights to each index. Hence, we construct alternative overall indices using principal components analysis (PCA) to determine the weight of each single variable (Filmer and Pritchett, 2001). Typically, a PCA is used to reduce the numbers of correlated variables to a smaller number of "dimensions." Column (3) aggregates the index using principal components analysis. While PCA was initially constructed for variables that are multivariate normal distributed, column (4) reports a PCA index that allows for ordinal variables and does not rely on a multivariate normal distribution Kolenikov and Angeles, 2004). Results underpin the overall effectiveness of our intervention. The effect of the additional feedback on aggregated indices is robust to the specification of the index.

Control for Unbalanced Variables. As could be seen from the baseline descriptives in Table 2, we find imbalances in the loan and saving index, while regarding the latter, means between control and finance training group differ only marginally at the 10 percent significance level. To further investigate the sources of these imbalances, we provide pre-intervention statistics for all variables that are part of these indices in Table A.12. As can be seen, these imbalances are driven by the following two variables: Savings (yes/no) and, Concrete Savings Goal (yes/no). All single variables of the business loan index are balanced, however the variable "Applied for 
Business Loan" is marginally insignificant and may cause this imbalance. To take these imbalances into account, we re-estimate our effects on the main outcome indices in Table A.13. by controlling for the sources of these imbalances. We provide two alternative ways, by controlling for the specific variables that cause these imbalances (Panel A) and by controlling for imbalanced indices (Panel B). Comparing the estimated treatment of both Panels with our main estimation results in Table 3 shows that even after controlling for baseline imbalances, the magnitude and significance of the main treatment effects remain stable and unaffected.

Spillover Effects. One potential threat to our estimation strategy arises if the control group would be indirectly affected by spillovers from the treatment group. Practically, this scenario could occur if assigned treatment firms share information regarding the finance training they received with assigned control firms who live close by. As a result, control firms would have the same knowledge gain compared to treated and adjust their behavior accordingly. Hence, the estimated treatment effect would be a lower-bound estimate, as the true treatment effect would be underestimated. Obviously, one crucial factor for spillover effects to occur is the distance between assigned control and treated entrepreneurs. We use GPS information on the location of each firm to measure the distance between each control and each treated firm. To test whether the control group is affected by spillovers, we measure the share of treated in a certain radius ("Share of treated in XYm radius") and interact this with the treatment assignment. The share of treated that is located close to the control group does not seem to affect them as shown in Appendix Tables A.14, A.15, A.16, A.17 for a radius of 10, 25, 75, 100m. There is a marginally significant coefficient at a $100 \mathrm{~m}$ radius, but this does not seem to be a systematic result.

\section{Conclusion}

Finance trainings are a standard tool that help small entrepreneurs, addressing their deficits in financial knowledge that limit the development of their businesses. In order to best use scarce training resources, there are various proposals on training design, among which a "ruleof-thumb" training approach seems to deliver. Another way to improve the effectiveness of financial education is counseling, basically providing an individualized training. While this also works well, it is costly. Thus, we follow an approach blending conventional classroom training 
and fully individualized training where we provide respondents feedback on their behavior and performance. The training, designed by us, covers the topics of investment strategies, savings, profits, risk diversification, separating business from personal finances, and record keeping. The length is about half an hour and, as such, quite cost effective. Trainers visit entrepreneurs at their business site, teach them, then leave a small booklet containing the training content. One treatment is a pure finance training at the workplace with "rule-of-thumb" elements as studied by Drexler et al. (2014). Another treatment provides the same finance training but with an additional feedback component, i.e. personalized information from the baseline survey on how the individual entrepreneur behaves and their firm financially performs.

We find that the finance training succeeds as expected but that finance training plus feedback has a surprisingly large additional impact. Simplifying results it seems fair to say that the addon does not change the structure of impacts across outcomes but that it mainly amplifies the effectiveness. Specifically, at a six-months horizon, the feedback training effect on the saving index is $0.257 \mathrm{SD}$ units and 0.258 SD units on the overall index, compared to 0.021 and 0.07 SD units for the finance training, respectively. An important factor for this advantage seems to be a motivational impact due to the personalized feedback, which is in line with feedback intervention theory.

These effects are not driven by increasing the input as the finance training needs an average of 28 minutes, while the feedback add-on takes only another 4 minutes. This means that the feedback training takes 14 percent longer than the pure finance training, while the effect on the overall index is more than three times larger. In sum, the short length of our intervention compared to related studies underpins that our feedback intervention is very promising. The time spent on business trainings is often between 15 hours (rule-of-thumb training provided by Drexler et al. (2014)) and 36 hours (personal initiative training provided by Campos et al. (2017)).

This raises the question: where do these large effects come from? First, it is known that financial education trainings work in general, that a "rule-of-thumb" approach tentatively works even better and that savings are typically the most successful outcome area. All this is confirmed by our study, so that neither effect size nor structure of effects is surprising. However, the large effect of the additional feedback is a new result. Obviously, this feedback information amplifies 
a desired change in behavior. While the training form of "personalized feedback" may have encouraging short-term results, there are caveats to be considered in future research. First, most of the realized positive effect measured after six months is lost at the horizon of 12 month horizon, indicating that the training intensity is insufficient or would benefit from repetition. Second, the personalized feedback requires appropriate available information about the targeted enterprises, otherwise its implementation will either be very expensive or impossible. Finally, this is a first study with a specific and small group of entrepreneurs, thus there is need for replication and extension. 


\section{References}

Banerjee, A. V. and E. Duflo (2014). Do firms want to borrow more? Testing credit constraints using a directed lending program. Review of Economic Studies 81(2), 572-607.

Berge, L. I. O., K. Bjorvatn, and B. Tungodden (2015). Human and financial capital for microenterprise development: Evidence from a field and lab experiment. Managment Science 61(4), $707-722$.

Bjorvatn, K. and B. Tungodden (2010). Teaching business in Tanzania: Evaluating participation and performance. Journal of the European Economic Association 8(2-3), 561-570.

Blattman, C., N. Fiala, and S. Martinez (2014). Generating skilled self-employment in developing countries: Experimental evidence from Uganda. Quarterly Journal of Economics 129(2), $697-752$.

Bloom, N., A. Mahajan, D. McKenzie, and J. Roberts (2010). Why do firms in developing countries have low productivity? American Economic Review 100(2), 619-623.

Bruhn, M., D. Karlan, and A. Schoar (2010). What capital is missing in developing countries? American Economic Review 100(2), 629-633.

Bruhn, M., D. Karlan, and A. Schoar (2018). The impact of consulting services on small and medium enterprises: Evidence from a randomized trial in Mexico. Journal of Political Economy 126(2), 635-687.

Bruhn, M. and D. McKenzie (2009). In pursuit of balance: Randomization in practice in development field experiments. American Economic Journal: Applied Economics 1(4), 200232.

Bruhn, M. and B. Zia (2013). Stimulating managerial capital in emerging markets: The impact of business training for young entrepreneurs. Journal of Development Effectiveness 5(2), $232-266$.

Calderone, M., N. Fiala, F. Mulaj, S. Sadhu, and L. Sarr (2018). Financial education and savings behavior: Evidence from a randomized experiment among low-income clients of branchless banking in India. Economic Development and Cultural Change 66(4), 793-825.

Campos, F., M. Frese, M. Goldstein, L. Iacovone, H. C. Johnson, D. McKenzie, and M. Mensmann (2017). Teaching personal initiative beats traditional training in boosting small business in West Africa. Science 357(6357), 1287-1290.

Carpena, F., S. Cole, J. Shapiro, and B. Zia (2019). The abcs of financial education: Experimental evidence on attitudes, behavior, and cognitive biases. Management Science 65(1), 346-369.

Cole, S., T. Sampsom, and B. Zia (2011). Prices or knowledge? What drives demand for financial services in emerging markets? The Journal of Finance 66 (6), 1933-1967.

De Mel, S., D. McKenzie, and C. Woodruff (2008). Returns to capital in microenterprises: Evidence from a field experiment. Quarterly Journal of Economics 123(4), 1329-1372.

De Mel, S., D. McKenzie, and C. Woodruff (2009). Measuring microenterprise profits: Must we ask how the sausage is made? Journal of Development Economics 88(1), 19-31.

De Mel, S., D. McKenzie, and C. Woodruff (2012). One-time transfers of cash or capital have long-lasting effects on microenterprises in sri lanka. Science 335(6071), 962-966.

De Mel, S., D. McKenzie, and C. Woodruff (2014). Business training and female enterprise startup, growth, and dynamics: Experimental evidence from sri lanka. Journal of Development Economics 106, 199-210. 
Drexler, A., G. Fischer, and A. Schoar (2014). Keeping it simple: Financial literacy and rules of thumb. American Economic Journal: Applied Economics 6(2), 1-31.

Duflo, E., R. Glennerster, and M. Kremer (2007). Using Randomization in Development Economics Research: A Toolkit, Volume 4 of Handbook of Development Economics, Chapter 61, pp. 3895 - 3962. Elsevier.

Filmer, D. and L. H. Pritchett (2001). Estimating wealth effects without expenditure dataor tears: An application to educational enrollments in states of India. Demography 38(1), $115-132$.

Gine, X. and G. Mansuri (2014). Money or ideas? A field experiment on constraints to entrepreneurship in rural Pakistan. Technical report, Washington, DC.: World Bank.

Hattie, J. and H. Timperley (2007). The power of feedback. Review of Educational Research 7\%, $81-112$.

Kaiser, T. and L. Menkhoff (2017). Does financial education impact financial literacy and financial behavior, and if so, when? World Bank Economic Review 31(3), 611-630.

Karlan, D., R. Knight, and C. Udry (2015). Consulting and capital experiments with microenterprise tailors in Ghana. Journal of Economic Behavior and Organization 118, 281-302.

Karlan, D. and M. Valdivia (2011). Teaching entrepreneurship: Impact of business training on microfinance clients and institutions. Review of Economics and Statistics 93(2), 510-527.

Karlin, B., J. F Zinger, and R. Ford (2015). The effects of feedback on energy conservation: A meta-analysis. Psychological Bulletin 141(6), 1205-1227.

Kling, J. R., J. B. Liebman, and L. F. Katz (2007). Experimental analysis of neighborhood effects. Econometrica 75(1), 83-119.

Kluger, A. and A. DeNisi (1996). The effects of feedback interventions on performance: A historical review, a meta-analysis, and a preliminary feedback intervention theory. Psychological Bulletin 119(2), 254-284.

Kluger, A. and A. DeNisi (1998). Feedback interventions: Toward the understanding of a double-edged sword. Current Directions in Psychological Science 7(3), 67-72.

Kluger, A. N., S. Lewinsohn, and J. R. Aiello (1994). The influence of feedback on mood: Linear effects on pleasantness and curvilinear effects on arousal. Organizational Behavior and Human Decision Processes 60(2), 276-299.

Kolenikov, S. and G. Angeles (2004). The use of discrete data in PCA: Theory, simulations, and applications to socioeconomic indices. Chapel Hill, N.C.: Carolina Population Center MEASURE Evaluation, University of North Carolina at Chapel Hill.

Lafortune, J., J. Riutort, and J. Tessada (2018). Role models or individual consulting: The impact of personalizing micro-entrepreneurship training. American Economic Journal: Applied Economics 10(4), 222-245.

McKenzie, D. (2012). Beyond baseline and follow-up: The case for more $\mathrm{t}$ in experiments. Journal of Development Economics 99(2), 210-221.

McKenzie, D. and C. Woodruff (2008). Experimental evidence on returns to capital and access to finance in Mexico. World Bank Economic Review 22(3), 457-482.

McKenzie, D. and C. Woodruff (2013). What are we learning from business training and entrepreneurship evaluations around the developing world? World Bank Research Observer 29(1), 48-82. 
Riper, H., A. van Straten, M. Keuken, F. Smit, G. Schippers, and P. Cuijpers (2009). Curbing problem drinking with personalized-feedback interventions. American Journal of Preventive Medicine 36(3), 247-55.

Schultz, P. W. (1999). Changing behavior with normative feedback interventions: A field experiment on curbside recycling. Basic and Applied Social Psychology 21(1), 25-36.

Westfall, P., P. S. Stanley Young, and S. Young (1993). Resampling-Based Multiple Testing: Examples and Methods for P-Value Adjustment, Volume 279 of A Wiley-Interscience publication. John Wiley \& Sons. 
Table 1: Pre-Intervention Summary Statistics by Industry Sectors

\begin{tabular}{|c|c|c|c|c|c|c|c|c|c|c|}
\hline & \multirow{2}{*}{\multicolumn{2}{|c|}{ All }} & \multicolumn{8}{|c|}{ Industry Sectors } \\
\hline & & & \multicolumn{2}{|c|}{ Services } & \multicolumn{2}{|c|}{ Manufacturing } & \multicolumn{2}{|c|}{ Retail } & \multicolumn{2}{|c|}{ Remaining } \\
\hline & $\begin{array}{c}\mathrm{n} \\
(1)\end{array}$ & $\begin{array}{c}\text { mean } \\
(2)\end{array}$ & $\begin{array}{c}\mathrm{n} \\
(3)\end{array}$ & $\begin{array}{c}\text { mean } \\
(4)\end{array}$ & $\begin{array}{c}\mathrm{n} \\
(5) \\
\end{array}$ & $\begin{array}{c}\text { mean } \\
(6) \\
\end{array}$ & $\begin{array}{c}\mathrm{n} \\
(7)\end{array}$ & $\begin{array}{c}\text { mean } \\
(8)\end{array}$ & $\begin{array}{c}\mathrm{n} \\
(9) \\
\end{array}$ & $\begin{array}{c}\text { mean } \\
(10)\end{array}$ \\
\hline Female & 500 & 0.41 & 55 & 0.62 & 236 & 0.31 & 192 & 0.48 & 17 & 0.47 \\
\hline Higher education $^{a}$ & 500 & 0.34 & 55 & 0.22 & 236 & 0.30 & 192 & 0.41 & 17 & 0.65 \\
\hline Capital stock (1000 UGX) & 498 & 5827.57 & 55 & 2576.82 & 235 & 9292.12 & 191 & 2519.11 & 17 & 5623.82 \\
\hline Inventory (1000 UGX) & 500 & 5082.89 & 55 & 1368.49 & 236 & 2280.71 & 192 & 9245.8 & 17 & 8984.53 \\
\hline Sales (1000 UGX) & 499 & 7430.36 & 55 & 1826.37 & 236 & 8207.77 & 191 & 7851.62 & 17 & 10035.53 \\
\hline
\end{tabular}

Source: Survey on micro and small enterprises in Uganda, wave October 2017, own calculations.

Notes: The table shows baseline summary statistics for the services, manufacturing, retail and remaining sectors.

${ }^{a}$ Higher education is a dichotomous variable, where $1=$ upper secondary degree (A-level) and more, and $0=$ lower secondary degree (O-level) and less. 
Table 2: Pre-Intervention Summary Statistics

\begin{tabular}{|c|c|c|c|c|c|c|c|}
\hline & $\begin{array}{l}\text { Obs. } \\
(1) \\
\end{array}$ & $\begin{array}{l}\text { Full Sample } \\
\text { mean } \\
(\mathrm{sd}) \\
(2) \\
\end{array}$ & $\begin{array}{c}\text { Control }(\mathrm{C}) \\
\text { mean } \\
(\mathrm{sd}) \\
(3) \\
\end{array}$ & $\begin{array}{l}\text { Finance } \\
\text { mean } \\
(\mathrm{sd}) \\
(4)\end{array}$ & $\begin{array}{l}\text { Training } \\
\text { Diff. from C } \\
\text { [p-value] } \\
(5)\end{array}$ & $\begin{array}{l}\text { Feedbac } \\
\text { mean } \\
(\mathrm{sd}) \\
(6)\end{array}$ & $\begin{array}{l}\text { Training } \\
\text { Diff. from C } \\
\text { [p-value] } \\
(7)\end{array}$ \\
\hline \multicolumn{8}{|c|}{ A. Entrepreneurial Characteristics } \\
\hline Age & 494 & $\begin{array}{l}37.61 \\
(9.99)\end{array}$ & $\begin{array}{l}38.03 \\
(9.68)\end{array}$ & $\begin{array}{l}37.06 \\
(9.90)\end{array}$ & $\begin{array}{l}-0.97 \\
{[0.37]}\end{array}$ & $\begin{array}{l}37.60 \\
(10.44)\end{array}$ & $\begin{array}{l}-0.43 \\
{[0.70]}\end{array}$ \\
\hline Household size & 500 & $\begin{array}{l}4.35 \\
(2.34)\end{array}$ & $\begin{array}{c}4.52 \\
(2.22)\end{array}$ & $\begin{array}{l}4.20 \\
(2.36)\end{array}$ & $\begin{array}{l}-0.33 \\
{[0.20]}\end{array}$ & $\begin{array}{c}4.32 \\
(2.44)\end{array}$ & $\begin{array}{l}-0.20 \\
{[0.43]}\end{array}$ \\
\hline Female & 500 & $\begin{array}{c}0.41 \\
(0.49)\end{array}$ & $\begin{array}{c}0.42 \\
(0.49)\end{array}$ & $\begin{array}{c}0.42 \\
(0.49)\end{array}$ & $\begin{array}{c}0.00 \\
{[1.00]}\end{array}$ & $\begin{array}{c}0.40 \\
(0.49)\end{array}$ & $\begin{array}{l}-0.01 \\
{[0.81]}\end{array}$ \\
\hline Higher education $^{a}$ & 500 & $\begin{array}{c}0.34 \\
(0.47)\end{array}$ & $\begin{array}{c}0.31 \\
(0.47)\end{array}$ & $\begin{array}{c}0.36 \\
(0.48)\end{array}$ & $\begin{array}{c}0.05 \\
{[0.35]}\end{array}$ & $\begin{array}{c}0.35 \\
(0.48)\end{array}$ & $\begin{array}{c}0.03 \\
{[0.51]}\end{array}$ \\
\hline Own-account & 498 & $\begin{array}{c}0.50 \\
(0.50)\end{array}$ & $\begin{array}{c}0.48 \\
(0.50)\end{array}$ & $\begin{array}{c}0.52 \\
(0.50)\end{array}$ & $\begin{array}{c}0.04 \\
{[0.44]}\end{array}$ & $\begin{array}{c}0.50 \\
(0.50)\end{array}$ & $\begin{array}{c}0.02 \\
{[0.70]}\end{array}$ \\
\hline Capital stock (1000 UGX) & 498 & $\begin{array}{c}5,827.57 \\
(22,633.07)\end{array}$ & $\begin{array}{c}4,852.10 \\
(14,577.70)\end{array}$ & $\begin{array}{c}4,595.17 \\
(10,653.70)\end{array}$ & $\begin{array}{c}-256.93 \\
{[0.85]}\end{array}$ & $\begin{array}{c}8,144.40 \\
(35,197.00)\end{array}$ & $\begin{array}{c}3,292.30 \\
{[0.27]}\end{array}$ \\
\hline \multicolumn{8}{|c|}{ B. Primary Outcome Indices ${ }^{b}$} \\
\hline Investment Index & 500 & $\begin{array}{c}0.02 \\
(1.01)\end{array}$ & $\begin{array}{c}0.00 \\
(1.00)\end{array}$ & $\begin{array}{c}0.02 \\
(0.92)\end{array}$ & $\begin{array}{c}0.02 \\
{[0.88]}\end{array}$ & $\begin{array}{c}0.01 \\
(1.09)\end{array}$ & $\begin{array}{c}0.01 \\
{[0.90]}\end{array}$ \\
\hline Saving Index & 500 & $\begin{array}{c}0.15 \\
(1.72)\end{array}$ & $\begin{array}{c}0.00 \\
(1.00)\end{array}$ & $\begin{array}{c}0.18 \\
(0.94)\end{array}$ & $\begin{array}{c}0.18 \\
{[0.10]}\end{array}$ & $\begin{array}{c}0.08 \\
(0.94)\end{array}$ & $\begin{array}{c}0.08 \\
{[0.48]}\end{array}$ \\
\hline Profit Index & 484 & $\begin{array}{c}0.03 \\
(1.19)\end{array}$ & $\begin{array}{c}0.00 \\
(1.00)\end{array}$ & $\begin{array}{c}0.07 \\
(1.29)\end{array}$ & $\begin{array}{c}0.07 \\
{[0.59]}\end{array}$ & $\begin{array}{l}-0.04 \\
(1.15)\end{array}$ & $\begin{array}{l}-0.04 \\
{[0.76]}\end{array}$ \\
\hline Loan Index & 500 & $\begin{array}{l}-0.07 \\
(0.81)\end{array}$ & $\begin{array}{c}0.00 \\
(1.00)\end{array}$ & $\begin{array}{l}-0.16 \\
(0.62)\end{array}$ & $\begin{array}{l}-0.16 \\
{[0.07]}\end{array}$ & $\begin{array}{l}-0.04 \\
(0.77)\end{array}$ & $\begin{array}{l}-0.04 \\
{[0.67]}\end{array}$ \\
\hline $\begin{array}{c}\text { Joint orthogonality tes } \\
\text { F-statistic } \\
\text { Prob }>\text { F } \\
\end{array}$ & & & & & $\begin{array}{c}1.05 \\
0.40488 \\
\end{array}$ & & $\begin{array}{c}0.18 \\
0.9978 \\
\end{array}$ \\
\hline
\end{tabular}

Source: Survey on micro and small enterprises in Uganda, wave October 2017, own calculations.

Notes: The table provides summary statistics of baseline data and mean comparisons between finance training group and control group (column (5)) and feedback training group and control group (column (7)). Standard deviations are in parenthesis, p-values for differences of means appear in squared brackets.

${ }^{a}$ Higher education is a dichotomous variable, where $1=$ upper secondary degree (A-level) and more, and $0=$ lower secondary degree (O-level) and less.

${ }^{b}$ All primary outcome indices are standardized, using the mean and standard deviation of the control group. 
Table 3: Intention-to-Treat Effects on Primary Outcome Indices

\begin{tabular}{|c|c|c|c|c|c|}
\hline & $\begin{array}{l}\text { Investment } \\
\text { Index } \\
(1)\end{array}$ & $\begin{array}{c}\text { Saving } \\
\text { Index } \\
(2)\end{array}$ & $\begin{array}{c}\text { Profit } \\
\text { Index } \\
(3)\end{array}$ & $\begin{array}{c}\text { Loan } \\
\text { Index } \\
(4)\end{array}$ & $\begin{array}{c}\text { Overall } \\
\text { Index } \\
(5)\end{array}$ \\
\hline \multicolumn{6}{|c|}{ Panel A: 6-months follow-up results } \\
\hline Finance Training & $\begin{array}{l}0.118 \\
(0.117)\end{array}$ & $\begin{array}{l}0.021 \\
(0.119)\end{array}$ & $\begin{array}{c}0.05 \\
(0.126)\end{array}$ & $\begin{array}{l}-.015 \\
(0.108)\end{array}$ & $\begin{array}{l}0.07 \\
(0.11)\end{array}$ \\
\hline Feedback Training & $\begin{array}{c}0.197^{*} \\
(0.114)\end{array}$ & $\begin{array}{c}0.257^{* *} \\
(0.114)\end{array}$ & $\begin{array}{l}0.233 \\
(0.148)\end{array}$ & $\begin{array}{l}-.037 \\
(0.109)\end{array}$ & $\begin{array}{c}0.258^{* *} \\
(0.113)\end{array}$ \\
\hline$\beta_{1}-\beta_{2}=0(\mathrm{p} \text {-value })^{a}$ & 0.51 & 0.07 & 0.28 & 0.82 & 0.13 \\
\hline $\mathrm{R}^{2}$ & 0.09 & 0.14 & 0.19 & 0.26 & 0.27 \\
\hline Mean (SD) of & 0.00 & 0.00 & 0.00 & 0.00 & 0.00 \\
\hline control group & $(1.00)$ & $(1.00)$ & $(1.00)$ & $(1.00)$ & $(1.00)$ \\
\hline Observations & 460 & 460 & 441 & 460 & 441 \\
\hline control for $\mathrm{y}_{t-1}$ & yes & yes & yes & yes & yes \\
\hline control for industry strata & yes & yes & yes & yes & yes \\
\hline \multicolumn{6}{|c|}{ Panel B: 12-months follow-up results } \\
\hline Finance Training & $\begin{array}{l}0.015 \\
(0.107)\end{array}$ & $\begin{array}{l}0.082 \\
(0.104)\end{array}$ & $\begin{array}{l}-.014 \\
(0.102)\end{array}$ & $\begin{array}{l}0.189 \\
(0.147)\end{array}$ & $\begin{array}{l}0.051 \\
(0.108)\end{array}$ \\
\hline Feedback Training & $\begin{array}{l}0.137 \\
(0.115)\end{array}$ & $\begin{array}{l}0.019 \\
(0.105)\end{array}$ & $\begin{array}{l}0.031 \\
(0.115)\end{array}$ & $\begin{array}{l}-.024 \\
(0.124)\end{array}$ & $\begin{array}{l}0.043 \\
(0.114)\end{array}$ \\
\hline April 2018 treatment & $\begin{array}{l}0.038 \\
(0.093)\end{array}$ & $\begin{array}{l}0.006 \\
(0.083)\end{array}$ & $\begin{array}{l}0.038 \\
(0.091)\end{array}$ & $\begin{array}{l}0.161 \\
(0.117)\end{array}$ & $\begin{array}{l}0.117 \\
(0.093)\end{array}$ \\
\hline$\beta_{1}-\beta_{2}=0(\mathrm{p} \text {-value })^{a}$ & 0.29 & 0.49 & 0.69 & 0.15 & 0.95 \\
\hline $\mathrm{R}^{2}$ & 0.10 & 0.02 & 0.28 & 0.06 & 0.14 \\
\hline Mean (SD) of & 0.00 & 0.00 & 0.00 & 0.00 & 0.00 \\
\hline control group & $(1.00)$ & $(1.00)$ & $(1.00)$ & $(1.00)$ & $(1.00)$ \\
\hline Observations & 454 & 454 & 443 & 454 & 443 \\
\hline control for $\mathrm{y}_{t-1}$ & yes & yes & yes & yes & yes \\
\hline control for industry strata & yes & yes & yes & yes & yes \\
\hline
\end{tabular}

Source: Survey on micro and small enterprises in Uganda, waves October 2017, April 2018, and October 2018, own calculations.

Notes: The table shows intention-to-treat effects on the "investment index" (column 1), "saving index" (column 2), "profit index" (column 3), "loan index" (column 4) and "overall index" (column 5). Detailed intention-to-treat effects on variables belonging to the "investment index" can be found in Table 4, on the "saving index" in Table 5 on the "profit index" in Table 6, on the "loan index" in Table 7. Panel A (B) provides effects on 6 (12)-months follow-up information. Standard errors in parentheses. * $p<0.1,{ }^{* *} p<0.05,{ }^{* * *} p<0.01$.

${ }^{a}$ Test for equality of estimated coefficients of being assigned to finance and feedback training. Coefficients refer to equation (1). 
Table 4: Intention-to-Treat Effects on Investment Index Components

\begin{tabular}{|c|c|c|c|c|c|}
\hline & $\begin{array}{l}\text { Investment } \\
\text { Index } \\
(1)\end{array}$ & $\begin{array}{l}\text { Investment } \\
\text { yes } / \text { no } \\
(2)\end{array}$ & $\begin{array}{c}\text { Investment } \\
\text { Amount } \\
(3)\end{array}$ & $\begin{array}{c}\text { Number } \\
\text { Investments } \\
(4)\end{array}$ & $\begin{array}{c}\text { Inventory } \\
\text { Amount } \\
(5)\end{array}$ \\
\hline Finance Training & $\begin{array}{l}0.118 \\
(0.117)\end{array}$ & $\begin{array}{l}0.037 \\
(0.057)\end{array}$ & $\begin{array}{c}-10.646 \\
(93.257)\end{array}$ & $\begin{array}{l}0.118 \\
(0.171)\end{array}$ & $\begin{array}{l}905.266 \\
(940.642)\end{array}$ \\
\hline Feedback Training & $\begin{array}{c}0.197^{*} \\
(0.114)\end{array}$ & $\begin{array}{l}0.015 \\
(0.056)\end{array}$ & $\begin{array}{c}75.554 \\
(102.994)\end{array}$ & $\begin{array}{c}0.308^{*} \\
(0.185)\end{array}$ & $\begin{array}{l}937.746 \\
(859.862)\end{array}$ \\
\hline FWER Finance Training & & 0.91 & 0.94 & 0.91 & 0.85 \\
\hline FWER Finance Training + Feedback & & 0.75 & 0.72 & 0.27 & 0.72 \\
\hline$\beta_{1}-\beta_{2}=0(\mathrm{p} \text {-value })^{a}$ & 0.51 & 0.70 & 0.39 & 0.29 & 0.98 \\
\hline $\mathrm{R}^{2}$ & 0.09 & 0.02 & 0.09 & 0.08 & 0.35 \\
\hline Mean (SD) of & 0.00 & 0.57 & 267.65 & 1.17 & 3278.84 \\
\hline control group & $(1.00)$ & $(0.50)$ & $(906.08)$ & $(1.56)$ & $(7552.10)$ \\
\hline Observations & 460 & 460 & 460 & 460 & 460 \\
\hline control for $\mathrm{y}_{t-1}$ & yes & yes & yes & yes & yes \\
\hline control for industry strata & yes & yes & yes & yes & yes \\
\hline
\end{tabular}

Source: Survey on micro and small enterprises in Uganda, waves October 2017, and April 2018, own calculations.

Notes: The table shows short-term intention-to-treat effects on variables belonging to the investment index. Values of investment amount (column 3) and inventory amount (column 5) are given in 1000 UGX. Standard errors in parentheses. FWER are family-wise error rates calculated based on Westfall et al. (1993). ${ }^{*} p<0.1,{ }^{* *} p<0.05$, *** $p<0.01$.

${ }^{a}$ Test for equality of estimated coefficients of being assigned to finance and feedback training. Coefficients refer to equation (1).

Table 5: Intention-to-Treat Effects on Saving Index Components

\begin{tabular}{|c|c|c|c|c|c|}
\hline & $\begin{array}{c}\text { Saving } \\
\text { Index } \\
(1) \\
\end{array}$ & $\begin{array}{c}\text { Saving } \\
\text { (yes } / \text { no) } \\
(2)\end{array}$ & $\begin{array}{c}\text { Formal } \\
\text { Saving } \\
(3)\end{array}$ & $\begin{array}{l}\text { Informal } \\
\text { Saving } \\
(4)\end{array}$ & $\begin{array}{c}\text { Concrete } \\
\text { Saving Goal (yes/no) } \\
(5)\end{array}$ \\
\hline Finance Training & $\begin{array}{l}0.021 \\
(0.119)\end{array}$ & $\begin{array}{l}-.010 \\
(0.036)\end{array}$ & $\begin{array}{l}279.123 \\
(250.938)\end{array}$ & $\begin{array}{l}27.393 \\
(54.969)\end{array}$ & $\begin{array}{l}-.003 \\
(0.025)\end{array}$ \\
\hline Feedback Training & $\begin{array}{c}0.257^{* *} \\
(0.114)\end{array}$ & $\begin{array}{l}0.023 \\
(0.034)\end{array}$ & $\begin{array}{l}262.798 \\
(211.544)\end{array}$ & $\begin{array}{c}162.008^{* * *} \\
\quad(56.485)\end{array}$ & $\begin{array}{l}0.013 \\
(0.024)\end{array}$ \\
\hline FWER Finance Training & & 0.95 & 0.73 & 0.92 & 0.95 \\
\hline FWER Finance Training + Feedback & & 0.66 & 0.60 & 0.04 & 0.66 \\
\hline$\beta_{1}-\beta_{2}=0(\mathrm{p} \text {-value })^{a}$ & 0.07 & 0.33 & 0.95 & 0.05 & 0.53 \\
\hline $\mathrm{R}^{2}$ & 0.14 & 0.05 & 0.23 & 0.11 & 0.01 \\
\hline Mean (SD) of & 0.00 & 0.88 & 953.60 & 254.47 & 0.95 \\
\hline control group & $(1.00)$ & $(0.33)$ & $(2121.08)$ & $(335.76)$ & $(0.22)$ \\
\hline Observations & 460 & 460 & 460 & 460 & 460 \\
\hline control for $\mathrm{y}_{t-1}$ & yes & yes & yes & yes & yes \\
\hline control for industry strata & yes & yes & yes & yes & yes \\
\hline
\end{tabular}

Source: Survey on micro and small enterprises in Uganda, waves October 2017, and April 2018, own calculations. Notes: The table shows short-term intention-to-treat effects on variables belonging to the saving index. Values of formal saving (column 3) and informal saving (column 4) are given in 1000 UGX. Standard errors in parentheses. FWER are family-wise error rates calculated based on Westfall et al. (1993). ${ }^{*} p<0.1,{ }^{* *} p<0.05,{ }^{* * *} p<0.01$.

${ }^{a}$ Test for equality of estimated coefficients of being assigned to finance and feedback training. Coefficients refer to equation (1). 
Table 6: Intention-to-Treat Effects on Profit Index Components

\begin{tabular}{|c|c|c|c|c|}
\hline & $\begin{array}{l}\text { Profit } \\
\text { Index } \\
(1)\end{array}$ & $\begin{array}{l}\text { Profit } \\
(2)\end{array}$ & $\begin{array}{l}\text { Value added } \\
\qquad(3)\end{array}$ & $\begin{array}{l}\text { Sales } \\
(4)\end{array}$ \\
\hline Finance Training & $\begin{array}{l}0.05 \\
(0.126)\end{array}$ & $\begin{array}{c}119.600 \\
(91.587)\end{array}$ & $\begin{array}{c}-281.833 \\
(638.359)\end{array}$ & $\begin{array}{c}-170.905 \\
(737.082)\end{array}$ \\
\hline Feedback Training & $\begin{array}{l}0.233 \\
(0.148)\end{array}$ & $\begin{array}{l}26.285 \\
(81.195)\end{array}$ & $\begin{array}{l}489.389 \\
(439.134)\end{array}$ & $\begin{array}{c}2141.606^{*} \\
(1246.624)\end{array}$ \\
\hline FWER Finance Training & & 0.37 & 0.81 & 0.81 \\
\hline FWER Feedback Training & & 0.57 & 0.43 & 0.13 \\
\hline$\beta_{1}-\beta_{2}=0(\mathrm{p} \text {-value })^{a}$ & 0.28 & 0.30 & 0.19 & 0.08 \\
\hline $\mathrm{R}^{2}$ & 0.19 & 0.16 & 0.03 & 0.31 \\
\hline $\begin{array}{l}\text { Mean (SD) of } \\
\text { control group }\end{array}$ & $\begin{array}{c}0.00 \\
(1.00)\end{array}$ & $\begin{array}{c}507.86 \\
(737.68)\end{array}$ & $\begin{array}{c}625.44 \\
(4423.19)\end{array}$ & $\begin{array}{c}4638.66 \\
(7623.48)\end{array}$ \\
\hline Observations & 441 & 441 & 441 & 441 \\
\hline control for $\mathrm{y}_{t-1}$ & yes & yes & yes & yes \\
\hline control for industry strata & yes & yes & yes & yes \\
\hline
\end{tabular}

Source: Survey on micro and small enterprises in Uganda, waves October 2017, and April 2018, own calculations.

Notes: The table shows short-term intention-to-treat effects on variables belonging to the profit index. Standard errors in parentheses. Values of profit (column 2), value added (column 3), and sales (column 4) are given in 1000 UGX. FWER are family-wise error rates calculated based on Westfall et al. (1993). ${ }^{*} p<0.1,{ }^{* *} p<0.05,{ }^{* * *} p<0.01$.

${ }^{a}$ Test for equality of estimated coefficients of being assigned to finance and feedback training. Coefficients refer to equation (1). 
Table 7: Intention-to-Treat Effects on Loan Index Components

\begin{tabular}{|c|c|c|c|}
\hline & $\begin{array}{l}\text { Loan } \\
\text { Index } \\
(1)\end{array}$ & $\begin{array}{c}\text { Applied for } \\
\text { Business Loan (yes/no) } \\
(2)\end{array}$ & $\begin{array}{l}\text { Business Loan } \\
\text { Amount } \\
(3)\end{array}$ \\
\hline Finance Training & $\begin{array}{l}-.015 \\
(0.108)\end{array}$ & $\begin{array}{l}-.030 \\
(0.038)\end{array}$ & $\begin{array}{l}65128.810 \\
(210590.000)\end{array}$ \\
\hline Feedback Training & $\begin{array}{l}-.037 \\
(0.109)\end{array}$ & $\begin{array}{l}-.029 \\
(0.039)\end{array}$ & $\begin{array}{r}-10487.070 \\
(204427.200)\end{array}$ \\
\hline FWER Finance Training & & 0.65 & 0.74 \\
\hline FWER Feedback Training & & 0.73 & 0.96 \\
\hline$\beta_{1}-\beta_{2}=0(\mathrm{p} \text {-value })^{a}$ & 0.82 & 0.97 & 0.68 \\
\hline $\mathrm{R}^{2}$ & 0.26 & 0.07 & 0.51 \\
\hline Mean (SD) of & 0.00 & 0.16 & 459801.32 \\
\hline control group & $(1.00)$ & $(0.37)$ & $(1.95 \mathrm{e}+06)$ \\
\hline Observations & 460 & 460 & 460 \\
\hline control for $\mathrm{y}_{t-1}$ & yes & yes & yes \\
\hline control for industry strata & yes & yes & yes \\
\hline
\end{tabular}

Source: Survey on micro and small enterprises in Uganda, waves October 2017, and April 2018, own calculations.

Notes: The table shows short-term intention-to-treat effects on variables belonging to the business loan index. Value of business loan amount (column 3) is given in 1000 UGX. Standard errors in parentheses. FWER are family-wise error rates calculated based on Westfall et al. (1993). ${ }^{*} p<0.1,{ }^{* *} p<0.05,{ }^{* * *} p<0.01$.

${ }^{a}$ Test for equality of estimated coefficients of being assigned to finance and feedback training. Coefficients refer to equation (1). 
Table 8: Heterogeneity Analysis: Short-term Intention-to-Treat Effects

\begin{tabular}{|c|c|c|c|c|c|}
\hline & $\begin{array}{l}\text { Investment } \\
\text { Index } \\
(1)\end{array}$ & $\begin{array}{c}\text { Saving } \\
\text { Index } \\
(2)\end{array}$ & $\begin{array}{c}\text { Profit } \\
\text { Index } \\
(3)\end{array}$ & $\begin{array}{c}\text { Loan } \\
\text { Index } \\
(4)\end{array}$ & $\begin{array}{l}\text { Overall } \\
\text { Index } \\
(5)\end{array}$ \\
\hline Finance Training & $\begin{array}{l}0.014 \\
(0.178)\end{array}$ & $\begin{array}{l}-.098 \\
(0.178)\end{array}$ & $\begin{array}{l}0.104 \\
(0.106)\end{array}$ & $\begin{array}{l}-.115 \\
(0.179)\end{array}$ & $\begin{array}{l}-.080 \\
(0.161)\end{array}$ \\
\hline Feedback Training & $\begin{array}{l}0.038 \\
(0.173)\end{array}$ & $\begin{array}{l}-.042 \\
(0.165)\end{array}$ & $\begin{array}{l}0.214 \\
(0.191)\end{array}$ & $\begin{array}{c}0.005 \\
(0.18)\end{array}$ & $\begin{array}{l}0.068 \\
(0.173)\end{array}$ \\
\hline Finance Training $*$ Male & $\begin{array}{l}0.193 \\
(0.234)\end{array}$ & $\begin{array}{l}0.192 \\
(0.241)\end{array}$ & $\begin{array}{l}-.129 \\
(0.198)\end{array}$ & $\begin{array}{l}0.155 \\
(0.222)\end{array}$ & $\begin{array}{l}0.239 \\
(0.214)\end{array}$ \\
\hline Feedback Training * Male & $\begin{array}{l}0.292 \\
(0.228)\end{array}$ & $\begin{array}{c}0.494^{* *} \\
(0.227)\end{array}$ & $\begin{array}{l}0.004 \\
(0.278)\end{array}$ & $\begin{array}{l}-.089 \\
(0.225)\end{array}$ & $\begin{array}{c}0.309 \\
(0.23)\end{array}$ \\
\hline Male & $\begin{array}{l}-.004 \\
(0.156)\end{array}$ & $\begin{array}{l}0.087 \\
(0.143)\end{array}$ & $\begin{array}{c}0.29^{* *} \\
(0.12)\end{array}$ & $\begin{array}{l}-.157 \\
(0.164)\end{array}$ & $\begin{array}{c}0.046 \\
(0.15)\end{array}$ \\
\hline Feedback Training + Feedback Training ${ }^{*}$ Male $=0$ & 0.03 & 0.00 & 0.28 & 0.52 & 0.01 \\
\hline $\mathrm{R}^{2}$ & 0.10 & 0.16 & 0.32 & 0.28 & 0.31 \\
\hline Mean (SD) of & 0.00 & 0.00 & 0.00 & 0.00 & 0.00 \\
\hline control group & $(1.00)$ & $(1.00)$ & $(1.00)$ & $(1.00)$ & $(1.00)$ \\
\hline Observations & 458 & 458 & 439 & 458 & 439 \\
\hline control for $\mathrm{y}_{t-1}$ & yes & yes & yes & yes & yes \\
\hline control for industry strata & yes & yes & yes & yes & yes \\
\hline
\end{tabular}

Source: Survey on micro and small enterprises in Uganda, waves October 2017, and April 2018, own calculations.

Notes: The table shows short-term heterogeneous treatment effects by gender and includes the interaction between both treatment groups with an indicator variable for being male. Standard errors in parentheses. * $p<0.1,{ }^{* *} p<0.05,{ }^{* * *} p<0.01$. 
Table 9: Effect of Gap on Saving Outcomes

\begin{tabular}{lccccc}
\hline \hline & $\begin{array}{c}\text { Saving } \\
\text { Index } \\
(1)\end{array}$ & $\begin{array}{c}\text { Saving } \\
(\text { yes/no }) \\
(2)\end{array}$ & $\begin{array}{c}\text { Formal } \\
\text { Saving } \\
(3)\end{array}$ & $\begin{array}{c}\text { Informal } \\
\text { Saving } \\
(4)\end{array}$ & $\begin{array}{c}\text { Saving } \\
\text { Goal } \\
(5)\end{array}$ \\
\hline Finance Training & 0.042 & -.017 & 238.349 & -12.745 & 0.029 \\
& $(0.136)$ & $(0.037)$ & $(278.465)$ & $(72.183)$ & $(0.027)$ \\
Feedback Training & 0.156 & -.012 & 16.261 & $140.683^{* *}$ & 0.013 \\
& $(0.128)$ & $(0.034)$ & $(225.204)$ & $(67.610)$ & $(0.025)$ \\
Finance Training * Gap & -.0002 & -.00005 & -.315 & 0.071 & -.0001 \\
& $(0.0004)$ & $(0.0001)$ & $(0.252)$ & $(0.108)$ & $(0.0001)$ \\
Feedback Training * Gap & $0.00009^{* *}$ & $0.00004^{*}$ & $0.436^{* * *}$ & -.002 & $-4.25 \mathrm{e}-06$ \\
& $(0.00004)$ & $(0.00002)$ & $(0.049)$ & $(0.015)$ & $(4.63 \mathrm{e}-06)$ \\
Gap & $-.00006^{* *}$ & $-.00004^{*}$ & $-.084^{* *}$ & $-.024^{* *}$ & $6.84 \mathrm{e}-06$ \\
& $(0.00003)$ & $(0.00002)$ & $(0.042)$ & $(0.01)$ & $(4.20 \mathrm{e}-06)$ \\
Obs. & 379 & 379 & 379 & 379 & 379 \\
\hline$\beta_{3}-\beta_{4}=0$ (p-value $)^{a}$ & 0.43 & 0.40 & 0.00 & 0.49 & 0.37 \\
\hline \hline
\end{tabular}

Source: Survey on micro and small enterprises in Uganda, waves October 2017, and April 2018, own calculations.

Notes: The table shows short-term intention-to-treat effects on variables belonging to the saving index with an additional interaction of the treatment assignment with the discrepancy between an individuals desired and actual saving goal amount, expressed in months ("Gap"). Values of formal saving (column 3) and informal saving (column 4) are given in 1000 UGX. Standard errors in parentheses. ${ }^{*} p<0.1,{ }^{* *} p<0.05,{ }^{* * *} p<0.01$. ${ }^{a}$ The notation $\beta_{3}-\beta_{4}=0$ (p-value) is based on equation (2) and tests whether the difference in finance training and feedback training interacted with the feedback gap are significantly different from each other. Specifically, it is tested: Finance Training * Gap Feedback Training ${ }^{*}$ Gap $=0$. 
Table 10: Heterogeneity Analysis: Effect of Saving Gap on Saving Outcomes

\begin{tabular}{|c|c|c|c|c|c|c|c|}
\hline & \multirow{2}{*}{$\begin{array}{l}\text { All } \\
\text { (1) }\end{array}$} & \multicolumn{2}{|c|}{ Gender } & \multicolumn{2}{|c|}{ Education $^{a}$} & \multicolumn{2}{|c|}{ Financial Literacy } \\
\hline & & $\begin{array}{c}\text { Female } \\
(2)\end{array}$ & $\begin{array}{c}\text { Male } \\
(3)\end{array}$ & $\begin{array}{c}\text { Lower } \\
(4)\end{array}$ & $\begin{array}{l}\text { Higher } \\
(5)\end{array}$ & $\begin{array}{c}<\text { Median } \\
(6)\end{array}$ & $\begin{array}{c}>\text { Median } \\
(7)\end{array}$ \\
\hline \multicolumn{8}{|c|}{ Dependent Variable: Saving Index } \\
\hline Finance Training & $\begin{array}{l}0.042 \\
(0.136)\end{array}$ & $\begin{array}{l}0.116 \\
(0.206)\end{array}$ & $\begin{array}{l}-.041 \\
(0.187)\end{array}$ & $\begin{array}{l}0.054 \\
(0.176)\end{array}$ & $\begin{array}{l}0.054 \\
(0.187)\end{array}$ & $\begin{array}{l}0.131 \\
(0.203)\end{array}$ & $\begin{array}{l}-.075 \\
(0.202)\end{array}$ \\
\hline Feedback Training & $\begin{array}{l}0.156 \\
(0.128)\end{array}$ & $\begin{array}{c}0.009 \\
(0.2)\end{array}$ & $\begin{array}{l}0.33^{*} \\
(0.181)\end{array}$ & $\begin{array}{l}0.304 \\
(0.204)\end{array}$ & $\begin{array}{l}0.093 \\
(0.174)\end{array}$ & $\begin{array}{l}0.282 \\
(0.221)\end{array}$ & $\begin{array}{l}0.108 \\
(0.155)\end{array}$ \\
\hline Finance Training * Gap & $\begin{array}{l}-.0002 \\
(0.0004)\end{array}$ & $\begin{array}{l}-.0007 \\
(0.0006)\end{array}$ & $\begin{array}{l}0.0004 \\
(0.0004)\end{array}$ & $\begin{array}{l}-.0008 \\
(0.0009)\end{array}$ & $\begin{array}{c}-.00005 \\
(0.0002)\end{array}$ & $\begin{array}{l}0.0002 \\
(0.0006)\end{array}$ & $\begin{array}{l}-.0003 \\
(0.0005)\end{array}$ \\
\hline Feedback Training $*$ Gap & $\begin{array}{c}0.00009^{* *} \\
(0.00004)\end{array}$ & $\begin{array}{l}-.0003 \\
(0.0003)\end{array}$ & $\begin{array}{c}0.0001^{* * *} \\
(0.00003)\end{array}$ & $\begin{array}{l}-.0003 \\
(0.0007)\end{array}$ & $\begin{array}{c}0.0001^{* * *} \\
(0.00003)\end{array}$ & $\begin{array}{l}-.0004 \\
(0.0004)\end{array}$ & $\begin{array}{c}0.0001^{* * *} \\
(0.00002)\end{array}$ \\
\hline Gap & $\begin{array}{c}-.00006^{* *} \\
(0.00003)\end{array}$ & $\begin{array}{l}0.00008 \\
(0.00009)\end{array}$ & $\begin{array}{c}-.00008^{* * *} \\
(0.00002)\end{array}$ & $\begin{array}{c}0.0002^{* *} \\
(0.00008)\end{array}$ & $\begin{array}{c}-.00008^{* * *} \\
(0.00002)\end{array}$ & $\begin{array}{l}0.00009 \\
(0.00009)\end{array}$ & $\begin{array}{c}-.0001^{* * *} \\
(0.00002)\end{array}$ \\
\hline$\beta_{3}-\beta_{4}=0(\mathrm{p} \text {-value })^{b}$ & 0.43 & 0.61 & 0.47 & 0.67 & 0.38 & 0.39 & 0.38 \\
\hline Observations & 379 & 154 & 223 & 142 & 232 & 207 & 172 \\
\hline
\end{tabular}

Source: Survey on micro and small enterprises in Uganda, waves October 2017, and April 2018, own calculations.

Notes: The table shows short-term intention-to-treat effects on variables belonging to the saving index with an additional interaction of the treatment assignment with the discrepancy between an individuals desired and actual saving goal amount, expressed in months ("Gap"). While column (1) shows results for the whole estimation sample, results are show by gender in columns (2)(female) and (3) (male), by educational level in columns (4) (lower) and (5) (higher) and by financial literacy level in columns (6) (below median) and 7 (above median). Standard errors in parentheses. ${ }^{*} p<0.1,{ }^{* *} p<0.05,{ }^{* * *} p<0.01$.

${ }^{a}$ Higher education is a dichotomous variable, where $1=$ lower secondary degree (O-level) and more, and $0=$ up to primary education.

${ }^{b}$ The notation $\beta_{3}-\beta_{4}=0$ (p-value) is based on equation (2) and tests whether the difference in finance training and feedback training interacted with the feedback gap are significantly different from each other. Specifically, it is tested: Finance Training * Gap - Feedback Training * Gap $=0$. 
Appendix to "The Effect of Personalized Feedback on Small Enterprises Finances in Uganda"

Appendix A: Tables A.1- A.17

Appendix B: Tables B.1- B.10 


\section{A Appendix A}

Table A.1: Overview Finance Training

\begin{tabular}{ll}
\hline \hline Topic & Content \\
$(1)$ & $(2)$ \\
\hline Investment in your Business & Business Investment \\
& Keep Business Profits the Same \\
& Increase Business Profits \\
& Plan an Investment \\
& Savings \\
& Loans \\
& Save Money to Invest \\
& Borrow Money to Invest \\
& Risky Investment \\
& Diversify your Risk \\
& Think about Reselling \\
Investments and their Risk & Money in Business \& Household I \\
& Money in Business \& Household II \\
Money for your Household & Control How Money is Spent \\
& Household Budget \\
\hline
\end{tabular}

Notes: The table provides an overview on the topics of the finance training (column (1)) and the specific content that is taught (column (2)).

${ }^{a}$ The topic "Money for your household" comprises business practices which are related to separating money between the business and the household. 
Table A.2: Sample Attrition

\begin{tabular}{lcccc}
\hline \hline & \multicolumn{3}{c}{ Businesses not interviewed during } \\
& midline & \multicolumn{2}{c}{ endline } \\
& $(1)$ & $(2)$ & $(3)$ & $(4)$ \\
\hline Finance Training & -.046 & -.048 & $-.058^{* *}$ & $-.060^{* *}$ \\
& $(0.03)$ & $(0.03)$ & $(0.029)$ & $(0.029)$ \\
Feedback Training & -.034 & -.034 & -.034 & -.034 \\
& $(0.031)$ & $(0.031)$ & $(0.031)$ & $(0.031)$ \\
Obs. & 500 & 500 & 500 & 500 \\
\hline Control for industry & & $\checkmark$ & & $\checkmark$ \\
\hline \hline
\end{tabular}

Source: Survey on micro and small enterprises in Uganda, waves October 2017, April 2018, and October 2018, own calculations.

Notes: The table reports estimations where indicators of training assignment are regressed on an indicator for attrition in the short (column 1 and 2) and long-term (column 3 and 4). Standard errors in parentheses. Standard errors clustered at firm level. ${ }^{*} p<0.1,{ }^{* *} p<0.05,{ }^{* * *} p<0.01$. 
Table A.3: Robustness Analysis: Short-and Longterm Intention-to-Treat Effects

\begin{tabular}{|c|c|c|c|c|c|}
\hline & $\begin{array}{c}\text { Investment } \\
\text { Index } \\
(1) \\
\end{array}$ & $\begin{array}{l}\text { Saving } \\
\text { Index } \\
(2)\end{array}$ & $\begin{array}{c}\text { Profit } \\
\text { Index } \\
(3) \\
\end{array}$ & $\begin{array}{c}\text { Loan } \\
\text { Index } \\
(4) \\
\end{array}$ & $\begin{array}{c}\text { Overall } \\
\text { Index } \\
(5) \\
\end{array}$ \\
\hline \multicolumn{6}{|l|}{ Panel A: Short-term effects } \\
\hline Finance Training & $\begin{array}{l}0.118 \\
(0.117)\end{array}$ & $\begin{array}{l}0.021 \\
(0.119)\end{array}$ & $\begin{array}{c}0.05 \\
(0.126)\end{array}$ & $\begin{array}{l}-.015 \\
(0.108)\end{array}$ & $\begin{array}{l}0.07 \\
(0.11)\end{array}$ \\
\hline Feedback Training & $\begin{array}{c}0.197^{*} \\
(0.114)\end{array}$ & $\begin{array}{c}0.257^{* *} \\
(0.114)\end{array}$ & $\begin{array}{l}0.233 \\
(0.148)\end{array}$ & $\begin{array}{l}-.037 \\
(0.109)\end{array}$ & $\begin{array}{c}0.258^{* *} \\
(0.113)\end{array}$ \\
\hline Obs. & 460 & 460 & 441 & 460 & 441 \\
\hline \multicolumn{6}{|c|}{ Panel B: Long-term effects (controlling for April 2018 treatment) } \\
\hline Finance Training & $\begin{array}{l}0.015 \\
(0.107)\end{array}$ & $\begin{array}{l}0.082 \\
(0.104)\end{array}$ & $\begin{array}{l}-.014 \\
(0.102)\end{array}$ & $\begin{array}{l}0.189 \\
(0.147)\end{array}$ & $\begin{array}{l}0.051 \\
(0.108)\end{array}$ \\
\hline Feedback Training & $\begin{array}{l}0.137 \\
(0.115)\end{array}$ & $\begin{array}{l}0.019 \\
(0.105)\end{array}$ & $\begin{array}{l}0.031 \\
(0.115)\end{array}$ & $\begin{array}{l}-.024 \\
(0.124)\end{array}$ & $\begin{array}{l}0.043 \\
(0.114)\end{array}$ \\
\hline April 2018 treatment & $\begin{array}{l}0.038 \\
(0.093)\end{array}$ & $\begin{array}{l}0.006 \\
(0.083)\end{array}$ & $\begin{array}{l}0.038 \\
(0.091)\end{array}$ & $\begin{array}{l}0.161 \\
(0.117)\end{array}$ & $\begin{array}{l}0.117 \\
(0.093)\end{array}$ \\
\hline Obs. & 454 & 454 & 443 & 454 & 443 \\
\hline \multicolumn{6}{|c|}{ Panel C: Long-term effects (interaction with April 2018 treatment) } \\
\hline Finance Training & $\begin{array}{l}-.160 \\
(0.165)\end{array}$ & $\begin{array}{l}0.019 \\
(0.158)\end{array}$ & $\begin{array}{l}0.082 \\
(0.144)\end{array}$ & $\begin{array}{l}0.297 \\
(0.197)\end{array}$ & $\begin{array}{l}-.004 \\
(0.153)\end{array}$ \\
\hline Feedback Training & $\begin{array}{r}-.038 \\
(0.17)\end{array}$ & $\begin{array}{l}0.145 \\
(0.149)\end{array}$ & $\begin{array}{l}0.093 \\
(0.158)\end{array}$ & $\begin{array}{l}0.104 \\
(0.128)\end{array}$ & $\begin{array}{l}0.122 \\
(0.158)\end{array}$ \\
\hline Finance Training $*$ April 2018 treatment & $\begin{array}{c}0.358^{*} \\
(0.212)\end{array}$ & $\begin{array}{l}0.132 \\
(0.212)\end{array}$ & $\begin{array}{l}-.195 \\
(0.211)\end{array}$ & $\begin{array}{l}-.220 \\
(0.286)\end{array}$ & $\begin{array}{l}0.112 \\
(0.219)\end{array}$ \\
\hline Feedback Training * April 2018 treatment & $\begin{array}{c}0.356 \\
(0.23)\end{array}$ & $\begin{array}{r}-.260 \\
(0.21)\end{array}$ & $\begin{array}{l}-.126 \\
(0.237)\end{array}$ & $\begin{array}{l}-.261 \\
(0.249)\end{array}$ & $\begin{array}{l}-.163 \\
(0.231)\end{array}$ \\
\hline April 2018 treatment & $\begin{array}{l}-.204 \\
(0.148)\end{array}$ & $\begin{array}{l}0.047 \\
(0.163)\end{array}$ & $\begin{array}{l}0.146 \\
(0.156)\end{array}$ & $\begin{array}{c}0.323^{* *} \\
(0.162)\end{array}$ & $\begin{array}{l}0.134 \\
(0.151)\end{array}$ \\
\hline Obs. & 454 & 454 & 443 & 454 & 443 \\
\hline \multicolumn{6}{|c|}{ Panel D: Pooled effects (controlling for April 2018 treatment) } \\
\hline Finance Training & $\begin{array}{l}0.084 \\
(0.082)\end{array}$ & $\begin{array}{l}0.045 \\
(0.087)\end{array}$ & $\begin{array}{l}0.012 \\
(0.088)\end{array}$ & $\begin{array}{l}-.010 \\
(0.076)\end{array}$ & $\begin{array}{l}0.025 \\
(0.086)\end{array}$ \\
\hline Feedback Training & $\begin{array}{l}0.14^{*} \\
(0.081)\end{array}$ & $\begin{array}{l}0.075 \\
(0.083)\end{array}$ & $\begin{array}{l}0.127 \\
(0.102)\end{array}$ & $\begin{array}{l}-.026 \\
(0.077)\end{array}$ & $\begin{array}{l}0.124 \\
(0.087)\end{array}$ \\
\hline April 2018 treatment & $\begin{array}{l}-.020 \\
(0.066)\end{array}$ & $\begin{array}{l}0.008 \\
(0.069)\end{array}$ & $\begin{array}{l}0.118 \\
(0.083)\end{array}$ & $\begin{array}{l}0.037 \\
(0.062)\end{array}$ & $\begin{array}{l}0.053 \\
(0.072)\end{array}$ \\
\hline April 2018 dummy & $\begin{array}{c}0.15^{* *} \\
(0.066)\end{array}$ & $\begin{array}{l}0.01 \\
(0.05)\end{array}$ & $\begin{array}{c}-.141^{* *} \\
(0.062)\end{array}$ & $\begin{array}{l}-.018 \\
(0.069)\end{array}$ & $\begin{array}{c}0.0006 \\
(0.054)\end{array}$ \\
\hline Obs. & 914 & 914 & 884 & 914 & 884 \\
\hline \multicolumn{6}{|c|}{ Panel E: Pooled effects (interaction with April 2018 treatment) } \\
\hline Finance Training & $\begin{array}{l}0.076 \\
(0.122)\end{array}$ & $\begin{array}{c}-.063 \\
(0.133)\end{array}$ & $\begin{array}{c}-.075 \\
(0.118)\end{array}$ & $\begin{array}{l}-.078 \\
(0.098)\end{array}$ & $\begin{array}{l}-.123 \\
(0.119)\end{array}$ \\
\hline Feedback Training & $\begin{array}{c}0.05 \\
(0.111)\end{array}$ & $\begin{array}{l}0.129 \\
(0.115)\end{array}$ & $\begin{array}{c}0.04 \\
(0.125)\end{array}$ & $\begin{array}{l}0.013 \\
(0.108)\end{array}$ & $\begin{array}{l}0.091 \\
(0.121)\end{array}$ \\
\hline Finance Training $*$ April 2018 treatment & $\begin{array}{l}0.015 \\
(0.161)\end{array}$ & $\begin{array}{l}0.224 \\
(0.176)\end{array}$ & $\begin{array}{l}0.175 \\
(0.182)\end{array}$ & $\begin{array}{l}0.141 \\
(0.148)\end{array}$ & $\begin{array}{c}0.303^{*} \\
(0.171)\end{array}$ \\
\hline Feedback Training * April 2018 treatment & $\begin{array}{c}0.184 \\
(0.16)\end{array}$ & $\begin{array}{l}-.111 \\
(0.165)\end{array}$ & $\begin{array}{l}0.178 \\
(0.208)\end{array}$ & $\begin{array}{r}-.079 \\
(0.16)\end{array}$ & $\begin{array}{l}0.065 \\
(0.176)\end{array}$ \\
\hline April 2018 treatment & $\begin{array}{l}-.087 \\
(0.109)\end{array}$ & $\begin{array}{l}-.031 \\
(0.124)\end{array}$ & $\begin{array}{c}-.0006 \\
(0.122)\end{array}$ & $\begin{array}{c}0.015 \\
(0.11)\end{array}$ & $\begin{array}{l}-.071 \\
(0.115)\end{array}$ \\
\hline April 2018 dummy & $\begin{array}{c}0.15^{* *} \\
(0.066)\end{array}$ & $\begin{array}{c}0.011 \\
(0.05)\end{array}$ & $\begin{array}{c}-.141^{* *} \\
(0.062)\end{array}$ & $\begin{array}{l}-.018 \\
(0.069)\end{array}$ & $\begin{array}{l}0.001 \\
(0.054)\end{array}$ \\
\hline Obs. & 914 & 914 & 884 & 914 & 884 \\
\hline
\end{tabular}

Source: Survey on micro and small enterprises in Uganda, waves October 2017, April 2018, and October 2018, own calculations.

Notes: Standard errors in parentheses. ${ }^{*} p<0.1,{ }^{* *} p<0.05,{ }^{* * *} p<0.01$. 
Table A.4: Heterogeneity Analysis by Gender: Intention-to-Treat Effects controlling for Baseline Differences I/II

\begin{tabular}{|c|c|c|c|c|c|c|}
\hline & \multicolumn{6}{|c|}{ Saving Index } \\
\hline & $(1)$ & $(2)$ & $(3)$ & $(4)$ & $(5)$ & $(6)$ \\
\hline Finance Training & $\begin{array}{l}-.098 \\
(0.178)\end{array}$ & $\begin{array}{l}-. .0006 \\
(0.184)\end{array}$ & $\begin{array}{l}-.102 \\
(0.18)\end{array}$ & $\begin{array}{l}-.029 \\
(0.19)\end{array}$ & $\begin{array}{c}-.043 \\
(0.203)\end{array}$ & $\begin{array}{l}-.162 \\
(0.206)\end{array}$ \\
\hline Feedback Training & $\begin{array}{c}-.042 \\
(0.165)\end{array}$ & $\begin{array}{c}-.024 \\
(0.178)\end{array}$ & $\begin{array}{l}-.077 \\
(0.165)\end{array}$ & $\begin{array}{c}-.009 \\
(0.173)\end{array}$ & $\begin{array}{c}0.041 \\
(0.189)\end{array}$ & $\begin{array}{c}-.139 \\
(0.197)\end{array}$ \\
\hline Finance Training $*$ Male & $\begin{array}{c}0.192 \\
(0.241)\end{array}$ & $\begin{array}{c}0.161 \\
(0.246)\end{array}$ & $\begin{array}{c}0.132 \\
(0.249)\end{array}$ & $\begin{array}{c}0.148 \\
(0.241)\end{array}$ & $\begin{array}{c}0.201 \\
(0.244)\end{array}$ & $\begin{array}{c}0.198 \\
(0.243)\end{array}$ \\
\hline Feedback Training * Male & $\begin{array}{c}0.494^{* *} \\
(0.227)\end{array}$ & $\begin{array}{l}0.454^{*} \\
(0.238)\end{array}$ & $\begin{array}{l}0.386^{*} \\
(0.233)\end{array}$ & $\begin{array}{c}0.456^{* *} \\
(0.225)\end{array}$ & $\begin{array}{c}0.511^{* *} \\
(0.233)\end{array}$ & $\begin{array}{c}0.511^{* *} \\
(0.231)\end{array}$ \\
\hline Finance Training $*$ Profit (1000 UGX) & & $\begin{array}{l}-.00009 \\
(0.0001)\end{array}$ & & & & \\
\hline Feedback Training * Profit (1000 UGX) & & $\begin{array}{c}5.15 \mathrm{e}-08 \\
(0.0001)\end{array}$ & & & & \\
\hline Finance Training * Sales (1000 UGX) & & & $\begin{array}{c}5.58 \mathrm{e}-06 \\
(1.00 \mathrm{e}-05)\end{array}$ & & & \\
\hline Feedback Training * Sales (1000 UGX) & & & $\begin{array}{c}1.00 \mathrm{e}-05 \\
(1.00 \mathrm{e}-05)\end{array}$ & & & \\
\hline Finance Training * Industry: Services & & & & $\begin{array}{c}-.309 \\
(0.312)\end{array}$ & & \\
\hline Feedback Training * Industry: Services & & & & $\begin{array}{c}-.116 \\
(0.322)\end{array}$ & & \\
\hline Finance Training * Industry: Manufacturing & & & & & $\begin{array}{c}-.116 \\
(0.238)\end{array}$ & \\
\hline Feedback Training * Industry: Manufacturing & & & & & $\begin{array}{c}-.185 \\
(0.233)\end{array}$ & \\
\hline Finance Training * Industry: Retail & & & & & & $\begin{array}{c}0.166 \\
(0.255)\end{array}$ \\
\hline Feedback Training * Industry: Retail & & & & & & $\begin{array}{c}0.247 \\
(0.249)\end{array}$ \\
\hline
\end{tabular}

Finance Training * Education

Feedback Training * Education

Finance Training * Ownaccount

Feedback Training * Ownaccount

Finance Training * Employees

Feedback Training * Employees

Finance Training * Capital stock

Feedback Training * Capital stock

Finance Training * Formal Savings

Feedback Training * Formal Savings

Finance Training * Pressure sharing extra income

Feedback Training * Pressure sharing extra income

Obs.

458

449

457

458

458

458

Source: Survey on micro and small enterprises in Uganda, waves October 2017, and April 2018, own calculations.

Notes: The table provides short-term heterogeneous treatment effects by gender while controlling for variables with significant baseline differences between men and women. Variables with significant baseline differences are interacted with treatment assignment. Table A.4 provides effects by controlling for the following baseline differences: business profits and sales, industry sector (services, manufacturing, retail). Table A.5 provides effects by controlling for the following baseline differences: education $(1=$ no education, $2(3)=$ started (completed) primary education, $4=$ completed O-level, $5=$ completed A-level, $6=$ completed university), indicator for being an own-account worker, number of employees, capital stock, formal savings and feeling pressured to share extra money $(1=$ condpletely agree, $2=$ agree, $3=$ neutral, $4=$ disagree, $5=$ completely disagree). Column 7 of Table A.5 controls for the full set of variables with baseline differences. Standard errors in parentheses. ${ }^{*} p<0.1,{ }^{* *} p<0.05,{ }^{* * *} p<0.01$. 
Table A.5: Heterogeneity Analysis by Gender: Intention-to-Treat Effects controlling for Baseline Differences II/II

\begin{tabular}{|c|c|c|c|c|c|c|c|}
\hline & \multicolumn{7}{|c|}{ Saving Index } \\
\hline & $(1)$ & $(2)$ & $(3)$ & $(4)$ & $(5)$ & $(6)$ & $(7)$ \\
\hline Finance Training & $\begin{array}{c}-.179 \\
(0.382)\end{array}$ & $\begin{array}{l}-.067 \\
(0.22)\end{array}$ & $\begin{array}{c}-.043 \\
(0.189)\end{array}$ & $\begin{array}{l}-.084 \\
(0.179)\end{array}$ & $\begin{array}{l}-.076 \\
(0.178)\end{array}$ & $\begin{array}{l}-.461 \\
(0.301)\end{array}$ & $\begin{array}{c}0.691 \\
(0.708)\end{array}$ \\
\hline Feedback Training & $\begin{array}{c}0.258 \\
(0.337)\end{array}$ & $\begin{array}{l}-.136 \\
(0.22)\end{array}$ & $\begin{array}{l}-.015 \\
(0.18)\end{array}$ & $\begin{array}{l}-.016 \\
(0.168)\end{array}$ & $\begin{array}{c}0.006 \\
(0.166)\end{array}$ & $\begin{array}{c}0.41 \\
(0.255)\end{array}$ & $\begin{array}{c}0.19 \\
(0.76)\end{array}$ \\
\hline Finance Training $*$ Male & $\begin{array}{c}0.185 \\
(0.238)\end{array}$ & $\begin{array}{c}0.151 \\
(0.235)\end{array}$ & $\begin{array}{c}0.207 \\
(0.237)\end{array}$ & $\begin{array}{c}0.195 \\
(0.243)\end{array}$ & $\begin{array}{c}0.18 \\
(0.233)\end{array}$ & $\begin{array}{c}0.166 \\
(0.242)\end{array}$ & $\begin{array}{c}0.13 \\
(0.243)\end{array}$ \\
\hline Feedback Training $*$ Male & $\begin{array}{c}0.517^{* *} \\
(0.23)\end{array}$ & $\begin{array}{c}0.501^{* *} \\
(0.228)\end{array}$ & $\begin{array}{c}0.511^{* *} \\
(0.225)\end{array}$ & $\begin{array}{c}0.531^{* *} \\
(0.23)\end{array}$ & $\begin{array}{c}0.546^{* *} \\
(0.225)\end{array}$ & $\begin{array}{l}0.52^{* *} \\
(0.229)\end{array}$ & $\begin{array}{c}0.549^{* *} \\
(0.242)\end{array}$ \\
\hline Finance Training * Profit (1000 UGX) & & & & & & & $\begin{array}{c}-.0003 \\
(0.0002)\end{array}$ \\
\hline Feedback Training $*$ Profit (1000 UGX) & & & & & & & $\begin{array}{c}-.0001 \\
(0.0002)\end{array}$ \\
\hline Finance Training * Sales (1000 UGX) & & & & & & & $\begin{array}{c}0.00003^{*} \\
(0.00002)\end{array}$ \\
\hline Feedback Training $*$ Sales (1000 UGX) & & & & & & & $\begin{array}{c}0.00004^{* *} \\
(0.00002)\end{array}$ \\
\hline Finance Training * Industry: Services & & & & & & & $\begin{array}{c}-1.158^{* *} \\
(0.532)\end{array}$ \\
\hline Feedback Training * Industry: Services & & & & & & & $\begin{array}{c}-.008 \\
(0.577)\end{array}$ \\
\hline Finance Training * Industry: Manufacturing & & & & & & & $\begin{array}{c}-1.183^{* *} \\
(0.489)\end{array}$ \\
\hline Feedback Training * Industry: Manufacturing & & & & & & & $\begin{array}{l}-.191 \\
(0.503)\end{array}$ \\
\hline Finance Training $*$ Industry: Retail & & & & & & & $\begin{array}{l}-.945^{*} \\
(0.516)\end{array}$ \\
\hline Feedback Training * Industry: Retail & & & & & & & $\begin{array}{c}0.032 \\
(0.507)\end{array}$ \\
\hline Finance Training * Education & $\begin{array}{l}0.022 \\
(0.09)\end{array}$ & & & & & & $\begin{array}{l}0.004 \\
(0.09)\end{array}$ \\
\hline Feedback Training * Education & $\begin{array}{l}-.080 \\
(0.08)\end{array}$ & & & & & & $\begin{array}{c}-.033 \\
(0.091)\end{array}$ \\
\hline Finance Training * Ownaccount & & $\begin{array}{c}0.019 \\
(0.233)\end{array}$ & & & & & $\begin{array}{c}0.021 \\
(0.344)\end{array}$ \\
\hline Feedback Training $*$ Ownaccount & & $\begin{array}{c}0.197 \\
(0.228)\end{array}$ & & & & & $\begin{array}{c}0.399 \\
(0.439)\end{array}$ \\
\hline Finance Training * Employees & & & $\begin{array}{c}-.081 \\
(0.099)\end{array}$ & & & & $\begin{array}{l}-.045 \\
(0.18)\end{array}$ \\
\hline Feedback Training $*$ Employees & & & $\begin{array}{l}-.046 \\
(0.103)\end{array}$ & & & & $\begin{array}{l}0.108 \\
(0.21)\end{array}$ \\
\hline Finance Training $*$ Capital stock & & & & $\begin{array}{r}-4.02 \mathrm{e}-06 \\
(9.99 \mathrm{e}-06)\end{array}$ & & & $\begin{array}{c}2.31 \mathrm{e}-06 \\
(1.00 \mathrm{e}-05)\end{array}$ \\
\hline Feedback Training * Capital stock & & & & $\begin{array}{r}-1.00 \mathrm{e}-05 \\
(7.06 \mathrm{e}-06)\end{array}$ & & & $\begin{array}{l}-5.25 \mathrm{e}-07 \\
(7.46 \mathrm{e}-06)\end{array}$ \\
\hline Finance Training * Formal Savings & & & & & $\begin{array}{c}-4.90 \mathrm{e}-06 \\
(0.00004)\end{array}$ & & $\begin{array}{c}0.00002 \\
(0.00006)\end{array}$ \\
\hline Feedback Training * Formal Savings & & & & & $\begin{array}{c}-.00007 \\
(0.00005)\end{array}$ & & $\begin{array}{l}-.0001^{* *} \\
(0.00005)\end{array}$ \\
\hline Finance Training * Pressure sharing extra income & & & & & & $\begin{array}{c}0.128 \\
(0.092)\end{array}$ & $\begin{array}{c}0.127 \\
(0.097)\end{array}$ \\
\hline Feedback Training $*$ Pressure sharing extra income & & & & & & $\begin{array}{l}-.154^{*} \\
(0.093)\end{array}$ & $\begin{array}{l}-.170^{*} \\
(0.094)\end{array}$ \\
\hline Obs. & 458 & 456 & 458 & 456 & 458 & 457 & 446 \\
\hline
\end{tabular}

Source: Survey on micro and small enterprises in Uganda, waves October 2017, and April 2018, own calculations.

Notes: The table provides short-term heterogeneous treatment effects by gender while controlling for variables with significant baseline differences between men and women. Variables with significant baseline differences are interacted with treatment assignment. Table A.4 provides effects by controlling for the following baseline differences: business profits and sales, industry sector (services, manufacturing, retail). Table A.5 provides effects by controlling for the following baseline differences: education $(1=$ no education, $2(3)=$ started (completed) primary education, $4=$ completed O-level, $5=$ completed A-level, $6=$ completed university), indicator for being an own-account worker, number of employees, capital stock, formal savings and feeling pressured to share extra money $(1=$ completely agree, $2=$ agree, $3=$ neutral, $4=$ disagree, $5=$ completely disagree). Column 7 of Table A.5 controls for the full set of variables with baseline differences. Standard errors in parentheses. ${ }^{*} p<0.1,{ }^{* *} p<0.05,{ }^{* * *} 2 p<0.01$. 
Table A.6: Heterogeneity Analysis by Educational Level: Intention-to-Treat Effects

\begin{tabular}{|c|c|c|c|c|c|}
\hline & $\begin{array}{l}\text { Investment } \\
\text { Index } \\
(1)\end{array}$ & $\begin{array}{c}\text { Saving } \\
\text { Index } \\
(2)\end{array}$ & $\begin{array}{c}\text { Profit } \\
\text { Index } \\
(3)\end{array}$ & $\begin{array}{l}\text { Loan } \\
\text { Index } \\
(4)\end{array}$ & $\begin{array}{c}\text { Overall } \\
\text { Index } \\
(5)\end{array}$ \\
\hline \multicolumn{6}{|l|}{ Panel A: Higher Education $=$ A-Level, University } \\
\hline Finance Training & $\begin{array}{c}0.308^{* *} \\
(0.128)\end{array}$ & $\begin{array}{l}-.030 \\
(0.135)\end{array}$ & $\begin{array}{l}0.124 \\
(0.138)\end{array}$ & $\begin{array}{l}0.115 \\
(0.123)\end{array}$ & $\begin{array}{l}0.185 \\
(0.124)\end{array}$ \\
\hline Feedback Training & $\begin{array}{c}0.219^{*} \\
(0.121)\end{array}$ & $\begin{array}{c}0.338^{* *} \\
(0.143)\end{array}$ & $\begin{array}{l}0.255 \\
(0.175)\end{array}$ & $\begin{array}{l}0.078 \\
(0.13)\end{array}$ & $\begin{array}{c}0.338^{* *} \\
(0.139)\end{array}$ \\
\hline Finance Training * Higher education (A-Level, University) & $\begin{array}{c}-.565^{* *} \\
(0.267)\end{array}$ & $\begin{array}{c}0.149 \\
(0.27)\end{array}$ & $\begin{array}{l}-.328 \\
(0.233)\end{array}$ & $\begin{array}{l}-.402 \\
(0.251)\end{array}$ & $\begin{array}{l}-.380 \\
(0.242)\end{array}$ \\
\hline Feedback Training $*$ Higher education (A-Level, University) & $\begin{array}{l}-.128 \\
(0.269)\end{array}$ & $\begin{array}{l}-.236 \\
(0.256)\end{array}$ & $\begin{array}{l}-.155 \\
(0.298)\end{array}$ & $\begin{array}{l}-.378 \\
(0.237)\end{array}$ & $\begin{array}{l}-.314 \\
(0.248)\end{array}$ \\
\hline Obs. & 455 & 455 & 437 & 455 & 437 \\
\hline $\begin{array}{l}\text { Panel B: Higher Education }=\text { O-Level, A-Level, University } \\
\text { Finance Training }\end{array}$ & $\begin{array}{c}0.259^{*} \\
(0.153)\end{array}$ & $\begin{array}{l}0.074 \\
(0.165)\end{array}$ & $\begin{array}{l}0.014 \\
(0.203)\end{array}$ & $\begin{array}{l}0.109 \\
(0.141)\end{array}$ & $\begin{array}{l}0.216 \\
(0.171)\end{array}$ \\
\hline Feedback Training & $\begin{array}{l}0.228 \\
(0.144)\end{array}$ & $\begin{array}{c}0.35^{* *} \\
(0.174)\end{array}$ & $\begin{array}{l}-.041 \\
(0.202)\end{array}$ & $\begin{array}{l}-.022 \\
(0.132)\end{array}$ & $\begin{array}{l}0.206 \\
(0.158)\end{array}$ \\
\hline Finance Training $*$ Higher education (O-Level, A-Level, University) & $\begin{array}{l}-.226 \\
(0.224)\end{array}$ & $\begin{array}{l}-.077 \\
(0.232)\end{array}$ & $\begin{array}{l}0.025 \\
(0.237)\end{array}$ & $\begin{array}{l}-.223 \\
(0.21)\end{array}$ & $\begin{array}{r}-.250 \\
(0.22)\end{array}$ \\
\hline Feedback Training * Higher education (O-Level, A-Level, University) & $\begin{array}{l}-.077 \\
(0.217)\end{array}$ & $\begin{array}{l}-.146 \\
(0.234)\end{array}$ & $\begin{array}{l}0.428 \\
(0.284)\end{array}$ & $\begin{array}{l}-.045 \\
(0.201)\end{array}$ & $\begin{array}{l}0.062 \\
(0.224)\end{array}$ \\
\hline Obs. & 455 & 455 & 437 & 455 & 437 \\
\hline
\end{tabular}

Source: Survey on micro and small enterprises in Uganda, waves October 2017, and April 2018, own calculations.

Notes: The table provides short-term heterogeneous treatment effects for different educational levels. In both panels, the trainings are interacted with an indicator for higher education. In Panel A, higher educated are defined as having an A-level (upper secondary degree) or university degree. In Panel B, the higher educated comprise in addition of the group of O-level educated (lower secondary degree). Standard errors in parentheses. ${ }^{*} p<0.1,{ }^{* *} p<0.05,{ }^{* * *} p<0.01$. 
Table A.7: Heterogeneity Analysis by Financial Literacy Level: Intention-to-Treat Effects

\begin{tabular}{lccccc}
\hline \hline & $\begin{array}{c}\text { Inv. } \\
\text { Index } \\
(1)\end{array}$ & $\begin{array}{c}\text { Saving } \\
\text { Index } \\
(2)\end{array}$ & $\begin{array}{c}\text { Profit } \\
\text { Index } \\
(3)\end{array}$ & $\begin{array}{c}\text { Loan } \\
\text { Index } \\
(4)\end{array}$ & $\begin{array}{c}\text { Overall } \\
\text { Index } \\
(5)\end{array}$ \\
\hline Panel A: Financial Literacy $>$ 25th percentile & & & & & \\
Finance Training & -.017 & 0.193 & -.119 & -.154 & -.053 \\
& $(0.169)$ & $(0.256)$ & $(0.187)$ & $(0.144)$ & $(0.18)$ \\
Feedback Training & 0.273 & 0.363 & -.204 & -.128 & 0.082 \\
& $(0.179)$ & $(0.243)$ & $(0.157)$ & $(0.143)$ & $(0.175)$ \\
Finance Training * Financial Literacy $>$ Q25 & 0.192 & -.224 & 0.201 & 0.186 & 0.167 \\
& $(0.221)$ & $(0.29)$ & $(0.226)$ & $(0.194)$ & $(0.222)$ \\
Feedback Training * Financial Literacy $>$ Q25 & -.098 & -.122 & $0.61^{* *}$ & 0.119 & 0.254 \\
& $(0.229)$ & $(0.279)$ & $(0.244)$ & $(0.196)$ & $(0.225)$ \\
Obs. & 460 & 460 & 441 & 460 & 441 \\
\hline Panel B: Financial Literacy $>$ 50th percentile & & & & & \\
Finance Training & -.138 & 0.115 & -.0001 & $-.268^{*}$ & -.151 \\
& $(0.139)$ & $(0.161)$ & $(0.138)$ & $(0.15)$ & $(0.138)$ \\
Feedback Training & 0.004 & 0.251 & -.054 & -.090 & -.004 \\
& $(0.15)$ & $(0.177)$ & $(0.12)$ & $(0.163)$ & $(0.154)$ \\
Finance Training * Financial Literacy $>$ Median & $0.549^{* *}$ & -.186 & 0.064 & $0.53^{* *}$ & $0.465^{* *}$ \\
& $(0.236)$ & $(0.246)$ & $(0.214)$ & $(0.21)$ & $(0.22)$ \\
Feedback Training * Financial Literacy $>$ Median & $0.407^{*}$ & 0.037 & $0.596^{* *}$ & 0.083 & $0.537^{* *}$ \\
& $(0.227)$ & $(0.226)$ & $(0.292)$ & $(0.21)$ & $(0.228)$ \\
Obs. & 460 & 460 & 441 & 460 & 441 \\
\hline Panel C: Financial Literacy $>$ 75th percentile & & & & & \\
Finance Training & 0.094 & 0.057 & 0.066 & -.145 & -.012 \\
Feedback Training & $(0.118)$ & $(0.135)$ & $(0.124)$ & $(0.113)$ & $(0.115)$ \\
Finance Training * Financial Literacy $>$ Q75 & 0.083 & 0.193 & 0.123 & -.055 & 0.112 \\
& $(0.118)$ & $(0.133)$ & $(0.15)$ & $(0.116)$ & $(0.124)$ \\
Obs. & 0.11 & -.212 & -.237 & $0.773^{* *}$ & 0.436 \\
& $(0.383)$ & $(0.281)$ & $(0.258)$ & $(0.311)$ & $(0.319)$ \\
\hline \hline & $0.581^{*}$ & 0.318 & 0.502 & 0.15 & $0.75^{* *}$ \\
& $(0.344)$ & $(0.233)$ & $(0.432)$ & $(0.285)$ & $(0.303)$ \\
& 460 & 460 & 441 & 460 & 441 \\
\hline
\end{tabular}

Source: Survey on micro and small enterprises in Uganda, waves October 2017, and April 2018, own calculations.

Notes: The table provides short-term heterogeneous treatment effects for different financial literacy levels. In Panel A, treatments are interacted with an indicator for financial literacy above the 25th percentile (Q25), in Panel B with an indicator for financial literacy above the 50th percentile (median), and in Panel $\mathrm{C}$ with an indicator for financial literacy above the 75th percentile (Q75). Standard errors in parentheses. ${ }^{*} p<0.1,{ }^{* *} p<0.05,{ }^{* * *} p<0.01$. 
Table A.8: Heterogeneity Analysis by Financial Literacy Level: Intention-to-Treat Effects

\begin{tabular}{|c|c|c|c|c|c|}
\hline & $\begin{array}{l}\text { Investment } \\
\text { Index } \\
(1)\end{array}$ & $\begin{array}{c}\text { Saving } \\
\text { Index } \\
(2)\end{array}$ & $\begin{array}{c}\text { Profit } \\
\text { Index } \\
(3)\end{array}$ & $\begin{array}{l}\text { Loan } \\
\text { Index } \\
(4)\end{array}$ & $\begin{array}{c}\text { Overall } \\
\text { Index } \\
(5)\end{array}$ \\
\hline Finance Training & $\begin{array}{l}0.153 \\
(0.183)\end{array}$ & $\begin{array}{l}0.115 \\
(0.204)\end{array}$ & $\begin{array}{l}0.036 \\
(0.163)\end{array}$ & $\begin{array}{l}-.138 \\
(0.191)\end{array}$ & $\begin{array}{l}0.095 \\
(0.189)\end{array}$ \\
\hline Feedback Training & $\begin{array}{c}0.375^{*} \\
(0.199)\end{array}$ & $\begin{array}{c}0.365^{*} \\
(0.212)\end{array}$ & $\begin{array}{c}0.327^{*} \\
(0.19)\end{array}$ & $\begin{array}{l}0.008 \\
(0.209)\end{array}$ & $\begin{array}{c}0.385^{*} \\
(0.2)\end{array}$ \\
\hline Finance Training * Services Sector & $\begin{array}{l}-.418 \\
(0.377)\end{array}$ & $\begin{array}{l}-.381 \\
(0.379)\end{array}$ & $\begin{array}{l}-.218 \\
(0.226)\end{array}$ & $\begin{array}{l}0.159 \\
(0.314)\end{array}$ & $\begin{array}{l}-.303 \\
(0.304)\end{array}$ \\
\hline Feedback Training $*$ Services Sector & $\begin{array}{c}-.521 \\
(0.37)\end{array}$ & $\begin{array}{l}-.322 \\
(0.376)\end{array}$ & $\begin{array}{c}-.482^{*} \\
(0.253)\end{array}$ & $\begin{array}{c}-.170 \\
(0.28)\end{array}$ & $\begin{array}{r}-.594^{*} \\
(0.304)\end{array}$ \\
\hline Services Sector & $\begin{array}{l}0.312 \\
(0.275)\end{array}$ & $\begin{array}{l}-.010 \\
(0.286)\end{array}$ & $\begin{array}{c}0.16 \\
(0.165)\end{array}$ & $\begin{array}{l}-.080 \\
(0.249)\end{array}$ & $\begin{array}{l}0.132 \\
(0.234)\end{array}$ \\
\hline Finance Training * Manufacturing Sector & $\begin{array}{l}0.005 \\
(0.253)\end{array}$ & $\begin{array}{l}-.135 \\
(0.267)\end{array}$ & $\begin{array}{l}-.050 \\
(0.237)\end{array}$ & $\begin{array}{l}0.255 \\
(0.242)\end{array}$ & $\begin{array}{l}-.012 \\
(0.245)\end{array}$ \\
\hline Feedback Training * Manufacturing Sector & $\begin{array}{l}-.308 \\
(0.255)\end{array}$ & $\begin{array}{l}-.146 \\
(0.265)\end{array}$ & $\begin{array}{l}-.062 \\
(0.305)\end{array}$ & $\begin{array}{l}0.005 \\
(0.253)\end{array}$ & $\begin{array}{l}-.110 \\
(0.26)\end{array}$ \\
\hline Manufacturing Sector & $\begin{array}{l}0.017 \\
(0.169)\end{array}$ & $\begin{array}{l}-.077 \\
(0.151)\end{array}$ & $\begin{array}{c}0.249^{*} \\
(0.137)\end{array}$ & $\begin{array}{l}-.042 \\
(0.186)\end{array}$ & $\begin{array}{l}0.024 \\
(0.162)\end{array}$ \\
\hline Finance Training * Remaining Sector & $\begin{array}{l}0.115 \\
(0.485)\end{array}$ & $\begin{array}{l}0.562 \\
(0.474)\end{array}$ & $\begin{array}{l}1.377 \\
(1.028)\end{array}$ & $\begin{array}{l}-.427 \\
(0.505)\end{array}$ & $\begin{array}{c}0.391 \\
(0.41)\end{array}$ \\
\hline Feedback Training * Remaining Sector & $\begin{array}{c}0.944^{*} \\
(0.561)\end{array}$ & $\begin{array}{l}-.048 \\
(0.439)\end{array}$ & $\begin{array}{l}-.735 \\
(0.641)\end{array}$ & $\begin{array}{c}-.610 \\
(0.47)\end{array}$ & $\begin{array}{l}-.359 \\
(0.621)\end{array}$ \\
\hline Remaining Sector & $\begin{array}{c}-.463^{* *} \\
(0.226)\end{array}$ & $\begin{array}{l}-.281 \\
(0.387)\end{array}$ & $\begin{array}{l}0.061 \\
(0.144)\end{array}$ & $\begin{array}{l}0.062 \\
(0.368)\end{array}$ & $\begin{array}{l}-.202 \\
(0.289)\end{array}$ \\
\hline Obs. & 460 & 460 & 441 & 460 & 441 \\
\hline
\end{tabular}

Source: Survey on micro and small enterprises in Uganda, waves October 2017, and April 2018, own calculations.

Notes: The table provides short-term heterogeneous treatment effects for different industry sectors. The reference category is the retail sector. Standard errors in parentheses. ${ }^{*} p<0.1,{ }^{* *} p<0.05$, *** $p<0.01$. 
Table A.9: Heterogeneity Analysis: Effect of Saving Gap on Saving Outcomes I/II

\begin{tabular}{|c|c|c|c|c|c|c|c|}
\hline & \multirow{2}{*}{$\begin{array}{l}\text { All } \\
(1)\end{array}$} & \multicolumn{2}{|c|}{ Gender } & \multicolumn{2}{|c|}{ Education $^{a}$} & \multicolumn{2}{|c|}{ Financial Literacy } \\
\hline & & $\begin{array}{c}\text { Female } \\
(2)\end{array}$ & $\begin{array}{c}\text { Male } \\
(3)\end{array}$ & $\begin{array}{c}\text { Lower } \\
(4)\end{array}$ & $\begin{array}{c}\text { Higher } \\
(5)\end{array}$ & $\begin{array}{c}<\text { Median } \\
(6)\end{array}$ & $\begin{array}{c}>\text { Median } \\
(7)\end{array}$ \\
\hline \multicolumn{8}{|c|}{ Panel A: Dependent Variable: Saving (yes/no) } \\
\hline Finance Training & $\begin{array}{l}-.017 \\
(0.037)\end{array}$ & $\begin{array}{l}-.017 \\
(0.06)\end{array}$ & $\begin{array}{l}-.016 \\
(0.048)\end{array}$ & $\begin{array}{l}0.017 \\
(0.052)\end{array}$ & $\begin{array}{l}-.027 \\
(0.049)\end{array}$ & $\begin{array}{l}0.052 \\
(0.056)\end{array}$ & $\begin{array}{l}-.062 \\
(0.051)\end{array}$ \\
\hline Feedback Training & $\begin{array}{l}-.012 \\
(0.034)\end{array}$ & $\begin{array}{l}-.012 \\
(0.062)\end{array}$ & $\begin{array}{l}0.027 \\
(0.042)\end{array}$ & $\begin{array}{c}0.022 \\
(0.056)\end{array}$ & $\begin{array}{l}-.007 \\
(0.047)\end{array}$ & $\begin{array}{l}0.067 \\
(0.061)\end{array}$ & $\begin{array}{l}-.031 \\
(0.042)\end{array}$ \\
\hline Finance Training * Gap & $\begin{array}{l}-.00005 \\
(0.0001)\end{array}$ & $\begin{array}{l}-.0002 \\
(0.0002)\end{array}$ & $\begin{array}{c}0.0001^{* * *} \\
(0.00005)\end{array}$ & $\begin{array}{c}-.0004^{* *} \\
(0.0002)\end{array}$ & $\begin{array}{l}0.00005 \\
(0.00006)\end{array}$ & $\begin{array}{l}-.0002 \\
(0.0002)\end{array}$ & $\begin{array}{c}-7.07 \mathrm{e}-07 \\
(0.0001)\end{array}$ \\
\hline Feedback Training * Gap & $\begin{array}{c}0.00004^{*} \\
(0.00002)\end{array}$ & $\begin{array}{l}-.0002 \\
(0.0002)\end{array}$ & $\begin{array}{c}0.00005^{* * *} \\
(0.00002)\end{array}$ & $\begin{array}{l}-.0003 \\
(0.0003)\end{array}$ & $\begin{array}{c}0.00005^{* *} \\
(0.00002)\end{array}$ & $\begin{array}{l}-.0002 \\
(0.0002)\end{array}$ & $\begin{array}{c}0.00008^{* * *} \\
(6.00 \mathrm{e}-06)\end{array}$ \\
\hline Gap & $\begin{array}{c}-.00004^{*} \\
(0.00002)\end{array}$ & $\begin{array}{l}0.00003 \\
(0.00002)\end{array}$ & $\begin{array}{c}-.00005^{* * *} \\
(0.00002)\end{array}$ & $\begin{array}{c}0.00006^{* *} \\
(0.00003)\end{array}$ & $\begin{array}{c}-.00005^{* *} \\
(0.00002)\end{array}$ & $\begin{array}{c}0.00004^{* *} \\
(0.00002)\end{array}$ & $\frac{-.00008^{* * *}}{(5.38 \mathrm{e}-06)}$ \\
\hline$\beta_{3}-\beta_{4}=0(\mathrm{p} \text {-value })^{b}$ & 0.40 & 0.97 & 0.09 & 0.92 & 0.95 & 0.88 & 0.53 \\
\hline \multicolumn{8}{|c|}{ Panel B: Dependent Variable: Formal Saving } \\
\hline Finance Training & $\begin{array}{l}238.349 \\
(278.465)\end{array}$ & $\begin{array}{l}479.694 \\
(370.681)\end{array}$ & $\begin{array}{c}53.444 \\
(392.305)\end{array}$ & $\begin{array}{l}196.715 \\
(326.988)\end{array}$ & $\begin{array}{l}299.978 \\
(408.544)\end{array}$ & $\begin{array}{l}419.748 \\
(374.446)\end{array}$ & $\begin{array}{c}-124.799 \\
(406.376)\end{array}$ \\
\hline Feedback Training & $\begin{array}{c}16.261 \\
(225.204)\end{array}$ & $\begin{array}{l}-40.480 \\
(250.439)\end{array}$ & $\begin{array}{c}97.069 \\
(355.090)\end{array}$ & $\begin{array}{l}276.535 \\
(405.736)\end{array}$ & $\begin{array}{r}-314.671 \\
(291.928)\end{array}$ & $\begin{array}{c}-168.324 \\
(305.886)\end{array}$ & $\begin{array}{l}136.832 \\
(368.658)\end{array}$ \\
\hline Finance Training * Gap & $\begin{array}{l}-.315 \\
(0.252)\end{array}$ & $\begin{array}{l}-.406 \\
(0.289)\end{array}$ & $\begin{array}{c}0.043 \\
(0.589)\end{array}$ & $\begin{array}{c}0.084 \\
(0.403)\end{array}$ & $\begin{array}{l}-.561^{*} \\
(0.295)\end{array}$ & $\begin{array}{l}1.175 \\
(1.653)\end{array}$ & $\begin{array}{l}-.400 \\
(0.28)\end{array}$ \\
\hline Feedback Training * Gap & $\begin{array}{c}0.436^{* * *} \\
(0.049)\end{array}$ & $\begin{array}{c}0.27 \\
(0.462)\end{array}$ & $\begin{array}{c}0.427^{* * *} \\
(0.058)\end{array}$ & $\begin{array}{l}1.821 \\
(1.919)\end{array}$ & $\begin{array}{c}0.458^{* * *} \\
(0.055)\end{array}$ & $\begin{array}{l}1.002 \\
(0.941)\end{array}$ & $\begin{array}{c}0.392^{* * *} \\
(0.044)\end{array}$ \\
\hline Gap & $\begin{array}{c}-.084^{* *} \\
(0.042)\end{array}$ & $\begin{array}{l}-.142 \\
(0.142)\end{array}$ & $\begin{array}{l}-.084^{*} \\
(0.048)\end{array}$ & $\begin{array}{l}-.081 \\
(0.134)\end{array}$ & $\begin{array}{c}-.114^{* *} \\
(0.049)\end{array}$ & $\begin{array}{l}-.131 \\
(0.084)\end{array}$ & $\begin{array}{c}-.062^{* *} \\
(0.031)\end{array}$ \\
\hline$\beta_{3}-\beta_{4}=0(\mathrm{p} \text {-value })^{b}$ & 0.00 & 0.18 & 0.51 & 0.38 & 0.00 & 0.93 & 0.00 \\
\hline \multicolumn{8}{|c|}{ Panel C: Dependent Variable: Informal Saving } \\
\hline Finance Training & $\begin{array}{l}-12.745 \\
(72.183)\end{array}$ & $\begin{array}{l}11.305 \\
(93.354)\end{array}$ & $\begin{array}{l}-45.633 \\
(106.515)\end{array}$ & $\begin{array}{c}4.502 \\
(67.960)\end{array}$ & $\begin{array}{l}-17.682 \\
(107.427)\end{array}$ & $\begin{array}{l}-45.522 \\
(84.533)\end{array}$ & $\begin{array}{c}7.213 \\
(140.458)\end{array}$ \\
\hline Feedback Training & $\begin{array}{c}140.683^{* *} \\
(67.610)\end{array}$ & $\begin{array}{l}83.405 \\
(71.353)\end{array}$ & $\begin{array}{c}204.228^{*} \\
(107.487)\end{array}$ & $\begin{array}{c}213.085^{* *} \\
(99.481)\end{array}$ & $\begin{array}{c}112.763 \\
(92.475)\end{array}$ & $\begin{array}{l}167.775 \\
(113.533)\end{array}$ & $\begin{array}{c}134.109^{*} \\
(81.431)\end{array}$ \\
\hline Finance Training * Gap & $\begin{array}{l}0.071 \\
(0.108)\end{array}$ & $\begin{array}{c}0.06 \\
(0.115)\end{array}$ & $\begin{array}{l}0.138 \\
(0.242)\end{array}$ & $\begin{array}{l}0.131 \\
(0.263)\end{array}$ & $\begin{array}{l}0.026 \\
(0.138)\end{array}$ & $\begin{array}{l}0.134 \\
(0.245)\end{array}$ & $\begin{array}{l}0.035 \\
(0.134)\end{array}$ \\
\hline Feedback Training * Gap & $\begin{array}{l}-.002 \\
(0.015)\end{array}$ & $\begin{array}{l}-.122 \\
(0.079)\end{array}$ & $\begin{array}{l}-.011 \\
(0.018)\end{array}$ & $\begin{array}{l}-.101 \\
(0.285)\end{array}$ & $\begin{array}{l}-.001 \\
(0.018)\end{array}$ & $\begin{array}{c}-.238^{* *} \\
(0.108)\end{array}$ & $\begin{array}{c}0.006 \\
(0.015)\end{array}$ \\
\hline Gap & $\begin{array}{c}-.024^{* *} \\
(0.01)\end{array}$ & $\begin{array}{l}-.040 \\
(0.025)\end{array}$ & $\begin{array}{l}-.023^{*} \\
(0.012)\end{array}$ & $\begin{array}{l}0.005 \\
(0.06)\end{array}$ & $\begin{array}{c}-.026^{* *} \\
(0.013)\end{array}$ & $\begin{array}{l}-.027 \\
(0.023)\end{array}$ & $\begin{array}{c}-.026^{* *} \\
(0.01)\end{array}$ \\
\hline$\beta_{3}-\beta_{4}=0(\mathrm{p} \text {-value })^{b}$ & 0.49 & 0.19 & 0.54 & 0.54 & 0.84 & 0.17 & 0.83 \\
\hline \multicolumn{8}{|c|}{ Panel D: Dependent Variable: Saving Goal } \\
\hline Finance Training & $\begin{array}{l}0.029 \\
(0.027)\end{array}$ & $\begin{array}{l}0.035 \\
(0.041)\end{array}$ & $\begin{array}{l}0.017 \\
(0.035)\end{array}$ & $\begin{array}{l}0.005 \\
(0.043)\end{array}$ & $\begin{array}{l}0.045 \\
(0.033)\end{array}$ & $\begin{array}{c}0.06 \\
(0.049)\end{array}$ & $\begin{array}{l}-.008 \\
(0.02)\end{array}$ \\
\hline Feedback Training & $\begin{array}{l}0.013 \\
(0.025)\end{array}$ & $\begin{array}{l}-.025 \\
(0.052)\end{array}$ & $\begin{array}{c}0.037 \\
(0.031)\end{array}$ & $\begin{array}{c}0.002 \\
(0.034)\end{array}$ & $\begin{array}{l}0.019 \\
(0.037)\end{array}$ & $\begin{array}{l}0.051 \\
(0.05)\end{array}$ & $\begin{array}{l}-.018 \\
(0.02)\end{array}$ \\
\hline Finance Training $*$ Gap & $\begin{array}{c}-.0001 \\
(0.0001)\end{array}$ & $\begin{array}{c}-.0002 \\
(0.0002)\end{array}$ & $\begin{array}{l}0.00005 \\
(0.00004)\end{array}$ & $\begin{array}{c}-.0003^{* *} \\
(0.0002)\end{array}$ & $\begin{array}{l}3.74 \mathrm{e}-06 \\
(0.00002)\end{array}$ & $\begin{array}{l}0.00008 \\
(0.00009)\end{array}$ & $\begin{array}{c}-.0001 \\
(0.0001)\end{array}$ \\
\hline Feedback Training * Gap & $\begin{array}{c}-4.25 \mathrm{e}-06 \\
(4.63 \mathrm{e}-06)\end{array}$ & $\begin{array}{l}0.00004 \\
(0.00005)\end{array}$ & $\begin{array}{c}-5.25 \mathrm{e}-06 \\
(4.26 \mathrm{e}-06)\end{array}$ & $\begin{array}{c}-2.35 \mathrm{e}-06 \\
(0.00004)\end{array}$ & $\begin{array}{c}-5.12 \mathrm{e}-06 \\
(4.95 \mathrm{e}-06)\end{array}$ & $\begin{array}{l}0.00002 \\
(0.00004)\end{array}$ & $\begin{array}{l}1.16 \mathrm{e}-06 \\
(1.46 \mathrm{e}-06)\end{array}$ \\
\hline Gap & $\begin{array}{l}6.84 \mathrm{e}-06 \\
(4.20 \mathrm{e}-06)\end{array}$ & $\begin{array}{c}1.00 \mathrm{e}-05 \\
(0.00002)\end{array}$ & $\begin{array}{l}5.60 \mathrm{e}-06 \\
(4.00 \mathrm{e}-06)\end{array}$ & $\begin{array}{l}4.10 \mathrm{e}-06 \\
(1.00 \mathrm{e}-05)\end{array}$ & $\begin{array}{c}7.66 \mathrm{e}-06^{*} \\
(4.58 \mathrm{e}-06)\end{array}$ & $\begin{array}{c}0.00003^{*} \\
(0.00002)\end{array}$ & $\begin{array}{l}1.02 \mathrm{e}-07 \\
(8.95 \mathrm{e}-07)\end{array}$ \\
\hline$\beta_{3}-\beta_{4}=0(\mathrm{p} \text {-value })^{b}$ & 0.37 & 0.19 & 0.14 & 0.05 & 0.61 & 0.50 & 0.32 \\
\hline Observations & 379 & 154 & 223 & 142 & 232 & 207 & 172 \\
\hline
\end{tabular}

Source: Survey on micro and small enterprises in Uganda, waves October 2017, and April 2018, own calculations.

Notes: The table shows short-term intention-to-treat effects on variables belonging to the saving index with an additional interaction of the treatment assignment with the discrepancy between an individuals desired and actual saving goal amount, expressed in months ("Gap")). While column (1) shows results for the whole estimation sample, results are show by gender in columns (2) (female) and (3) (male), by educational level in columns (4) (lower) and (5) (higher) and by financial literacy level in columns (6) (below median) and 7 (above median). Standard errors in parentheses. ${ }^{*} p<0.1,{ }^{* *} p<0.05,{ }^{* * *} p<0.01$.

${ }^{a}$ Higher education is a dichotomous variable, where $1=$ lower secondary degree (O-level) and more, and $0=$ up to primary education.

${ }^{b}$ The notation $\beta_{3}-\beta_{4}=0$ (p-value) is based on equation (2) and tests whether the difference in finance training and feedback training interacted with the feedback gap are significantly different from each other. Specifically, it is tested: Finance Training * Gap - Feedback Training * Gap $=0$. 
Table A.10: Heterogeneity Analysis: Effect of Saving Gap on Saving Outcomes II/II

\begin{tabular}{|c|c|c|c|c|}
\hline & $\begin{array}{l}\text { All } \\
(1)\end{array}$ & $\begin{array}{c}\text { Services } \\
(2)\end{array}$ & $\begin{array}{c}\text { Manufacturing } \\
\text { (3) }\end{array}$ & $\begin{array}{c}\text { Retail } \\
(4)\end{array}$ \\
\hline \multicolumn{5}{|c|}{ Panel A: Dependent Variable: Saving Index } \\
\hline Finance Training & $\begin{array}{c}0.032 \\
(0.144)\end{array}$ & $\begin{array}{l}-.427^{*} \\
(0.246)\end{array}$ & $\begin{array}{l}0.006 \\
(0.19)\end{array}$ & $\begin{array}{c}0.233 \\
(0.276)\end{array}$ \\
\hline Feedback Training & $\begin{array}{c}0.142 \\
(0.129)\end{array}$ & $\begin{array}{l}-.130 \\
(0.386)\end{array}$ & $\begin{array}{c}0.118 \\
(0.189)\end{array}$ & $\begin{array}{c}0.394 \\
(0.248)\end{array}$ \\
\hline Finance Training * Gap & $\begin{array}{l}-.0001 \\
(0.0002)\end{array}$ & $\begin{array}{c}-.002 \\
(0.001)\end{array}$ & $\begin{array}{l}-.0001 \\
(0.0004)\end{array}$ & $\begin{array}{c}-1.00 \mathrm{e}-05 \\
(0.0002)\end{array}$ \\
\hline Feedback Training * Gap & $\begin{array}{c}0.0002^{* * *} \\
(0.00003)\end{array}$ & $\begin{array}{l}-.0003 \\
(0.001)\end{array}$ & $\begin{array}{c}3.29 \mathrm{e}-06 \\
(0.0004)\end{array}$ & $\begin{array}{c}0.0001 \\
(0.0002)\end{array}$ \\
\hline Gap & $\begin{array}{c}-.00008^{* * *} \\
(0.00002)\end{array}$ & $\begin{array}{c}0.00009 \\
(0.00008)\end{array}$ & $\begin{array}{c}-.0001^{* * *} \\
(0.00002)\end{array}$ & $\begin{array}{l}-.00004 \\
(0.0002)\end{array}$ \\
\hline Obs. & 379 & 48 & 182 & 134 \\
\hline \multicolumn{5}{|c|}{ Panel B: Dependent Variable: Any Saving } \\
\hline Finance Training & $\begin{array}{l}-.017 \\
(0.037)\end{array}$ & $\begin{array}{c}0.051 \\
(0.108)\end{array}$ & $\begin{array}{l}-.034 \\
(0.06)\end{array}$ & $\begin{array}{c}0.04 \\
(0.056)\end{array}$ \\
\hline Feedback Training & $\begin{array}{c}-.012 \\
(0.034)\end{array}$ & $\begin{array}{c}-.034 \\
(0.137)\end{array}$ & $\begin{array}{c}-.010 \\
(0.059)\end{array}$ & $\begin{array}{c}0.062 \\
(0.053)\end{array}$ \\
\hline Finance Training * Gap & $\begin{array}{l}-.00005 \\
(0.0001)\end{array}$ & $\begin{array}{c}-.001 \\
(0.0009)\end{array}$ & $\begin{array}{l}-.0001 \\
(0.0002)\end{array}$ & $\begin{array}{c}-.00004 \\
(0.00005)\end{array}$ \\
\hline Feedback Training * Gap & $\begin{array}{c}0.00004^{*} \\
(0.00002)\end{array}$ & $\begin{array}{c}-.0003 \\
(0.0005)\end{array}$ & $\begin{array}{l}-.00005 \\
(0.0002)\end{array}$ & $\begin{array}{l}-.00007^{*} \\
(0.00004)\end{array}$ \\
\hline Gap & $\begin{array}{c}-.00004^{*} \\
(0.00002)\end{array}$ & $\begin{array}{c}0.00007 \\
(0.00008)\end{array}$ & $\begin{array}{c}-.00006^{* * *} \\
(0.00002)\end{array}$ & $\begin{array}{l}0.00007^{*} \\
(0.00004)\end{array}$ \\
\hline Obs. & 379 & 48 & 182 & 134 \\
\hline \multicolumn{5}{|c|}{ Panel C: Dependent Variable: Saving Formal } \\
\hline Finance Training & $\begin{array}{c}238.349 \\
(278.465)\end{array}$ & $\begin{array}{c}-636.387^{*} \\
(365.943)\end{array}$ & $\begin{array}{c}232.717 \\
(401.684)\end{array}$ & $\begin{array}{c}455.345 \\
(490.651)\end{array}$ \\
\hline Feedback Training & $\begin{array}{c}16.261 \\
(225.204)\end{array}$ & $\begin{array}{c}395.320 \\
(455.767)\end{array}$ & $\begin{array}{l}-218.268 \\
(310.519)\end{array}$ & $\begin{array}{c}122.526 \\
(377.643)\end{array}$ \\
\hline Finance Training * Gap & $\begin{array}{c}-.315 \\
(0.252)\end{array}$ & $\begin{array}{l}0.548 \\
(0.84)\end{array}$ & $\begin{array}{l}-.036 \\
(0.485)\end{array}$ & $\begin{array}{c}-.380 \\
(0.461)\end{array}$ \\
\hline Feedback Training * Gap & $\begin{array}{c}0.436^{* * *} \\
(0.049)\end{array}$ & $\begin{array}{c}0.356 \\
(1.463)\end{array}$ & $\begin{array}{l}0.695 \\
(0.58)\end{array}$ & $\begin{array}{c}0.424 \\
(0.321)\end{array}$ \\
\hline Gap & $\begin{array}{c}-.084^{* *} \\
(0.042)\end{array}$ & $\begin{array}{l}-.077 \\
(0.06)\end{array}$ & $\begin{array}{c}-.098^{* * *} \\
(0.038)\end{array}$ & $\begin{array}{l}-.067 \\
(0.32)\end{array}$ \\
\hline Obs. & 379 & 48 & 182 & 134 \\
\hline \multicolumn{5}{|c|}{ Panel D: Dependent Variable: Saving Informal } \\
\hline Finance Training & $\begin{array}{l}-12.745 \\
(72.183)\end{array}$ & $\begin{array}{l}-163.419 \\
(106.806)\end{array}$ & $\begin{array}{l}-26.586 \\
(79.170)\end{array}$ & $\begin{array}{c}60.483 \\
(161.837)\end{array}$ \\
\hline Feedback Training & $\begin{array}{c}140.683^{* *} \\
(67.610)\end{array}$ & $\begin{array}{c}67.465 \\
(186.235)\end{array}$ & $\begin{array}{c}175.311^{*} \\
(95.704)\end{array}$ & $\begin{array}{c}217.275 \\
(145.846)\end{array}$ \\
\hline Finance Training * Gap & $\begin{array}{c}0.071 \\
(0.108)\end{array}$ & $\begin{array}{l}-.195 \\
(0.229)\end{array}$ & $\begin{array}{c}0.049 \\
(0.163)\end{array}$ & $\begin{array}{c}0.111 \\
(0.148)\end{array}$ \\
\hline Feedback Training * Gap & $\begin{array}{l}-.002 \\
(0.015)\end{array}$ & $\begin{array}{l}-.562^{*} \\
(0.316)\end{array}$ & $\begin{array}{l}-.128^{*} \\
(0.072)\end{array}$ & $\begin{array}{c}0.049 \\
(0.077)\end{array}$ \\
\hline Gap & $\begin{array}{c}-.024^{* *} \\
(0.01)\end{array}$ & $\begin{array}{c}-.076^{* * *} \\
(0.027)\end{array}$ & $\begin{array}{c}-.019^{* *} \\
(0.009)\end{array}$ & $\begin{array}{l}-.071 \\
(0.076)\end{array}$ \\
\hline Obs. & 379 & 48 & 182 & 134 \\
\hline \multicolumn{5}{|c|}{ Panel E: Dependent Variable: Saving Goal } \\
\hline Finance Training & $\begin{array}{c}0.029 \\
(0.027)\end{array}$ & $\begin{array}{l}-.020 \\
(0.113)\end{array}$ & $\begin{array}{c}0.042 \\
(0.036)\end{array}$ & $\begin{array}{c}0.038 \\
(0.051)\end{array}$ \\
\hline Feedback Training & $\begin{array}{c}0.013 \\
(0.025)\end{array}$ & $\begin{array}{c}0.073 \\
(0.073)\end{array}$ & $\begin{array}{l}-.017 \\
(0.046)\end{array}$ & $\begin{array}{c}0.036 \\
(0.051)\end{array}$ \\
\hline Finance Training * Gap & $\begin{array}{c}-.0001 \\
(0.0001)\end{array}$ & $\begin{array}{c}0.0004 \\
(0.0004)\end{array}$ & $\begin{array}{c}-.0002 \\
(0.0002)\end{array}$ & $\begin{array}{c}-.00004 \\
(0.00005)\end{array}$ \\
\hline Feedback Training * Gap & $\begin{array}{c}-4.25 \mathrm{e}-06 \\
(4.63 \mathrm{e}-06)\end{array}$ & $\begin{array}{c}-5.85 \mathrm{e}-06 \\
(1.00 \mathrm{e}-05)\end{array}$ & $\begin{array}{c}0.00005 \\
(0.00004)\end{array}$ & $\begin{array}{c}-.00006 \\
(0.00004)\end{array}$ \\
\hline Gap & $\begin{array}{c}6.84 \mathrm{e}-06 \\
(4.20 \mathrm{e}-06)\end{array}$ & $\begin{array}{c}5.85 \mathrm{e}-06 \\
(1.00 \mathrm{e}-05)\end{array}$ & $\begin{array}{c}3.02 \mathrm{e}-06 \\
(2.48 \mathrm{e}-06)\end{array}$ & $\begin{array}{c}0.00006 \\
(0.00004)\end{array}$ \\
\hline Obs. & 379 & 48 & 182 & 134 \\
\hline
\end{tabular}

Source: Survey on micro and small enterprises in Uganda, waves October 2017, and April 2018, own calculations.

Notes: The table shows short-term intention-to-treat effects on variables belonging to the savings index with an additional interaction of the treatment assignment with the discrepancy between an individuals4 4 esired and actual saving goal amount, expressed in months ("Gap"). Column (1) shows results for the whole estimation sample, results are show by industry in columns (2) (services) and (3) (manufacturing), and (4) (retail). We neglect estimation results for the remaining sector due to low number of observations (below 20). Standard errors in parentheses. ${ }^{*} p<0.1,{ }^{* *} p<0.05,{ }^{* * *} p<0.01$. 
Table A.11: Robustness Analysis: Intention-to-Treat Effects on Overall Index

\begin{tabular}{lcccc}
\hline \hline & $\begin{array}{c}\text { Overall } \\
\text { Index }\end{array}$ & $\begin{array}{c}\text { Average } \\
\text { over all Variables }\end{array}$ & $\begin{array}{c}\text { Principal } \\
\text { component } \\
\text { (continuous) } \\
(1)\end{array}$ & $\begin{array}{c}\text { Principal } \\
\text { component } \\
\text { (ordinal) } \\
(4)\end{array}$ \\
\hline Finance Training & 0.07 & 0.062 & 0.113 & 0.071 \\
& $(0.11)$ & $(0.1)$ & $(0.114)$ & $(0.07)$ \\
Feedback Training & $0.258^{* *}$ & $0.286^{* * *}$ & $0.308^{* * *}$ & $0.192^{* * *}$ \\
Obs. & $(0.113)$ & $(0.101)$ & $(0.116)$ & $(0.072)$ \\
\hline
\end{tabular}

Source: Survey on micro and small enterprises in Uganda, waves October 2017 and April 2018, own calculations.

Notes: The table provides a robustness analysis on the short-term intention-totreat effects of treatment assignment on the the overall index. Column 1 defines the overall index as the average over all primary standardized outcome indices, column 2 defines the overall index as the average over all variables which are part of the four primary overall indices, both specifications weigh each component of the index equally. In column 3 and 4 we allow for component specific weights by using principal component analysis for continuous variables (assuming a multivariate normal distribution) and for ordinal variables. Standard errors in parentheses.

${ }^{*} p<0.1,{ }^{* *} p<0.05,{ }^{* * *} p<0.01$.

Table A.12: Pre-Intervention Summary Statistics of Saving Index and Loan Index Components

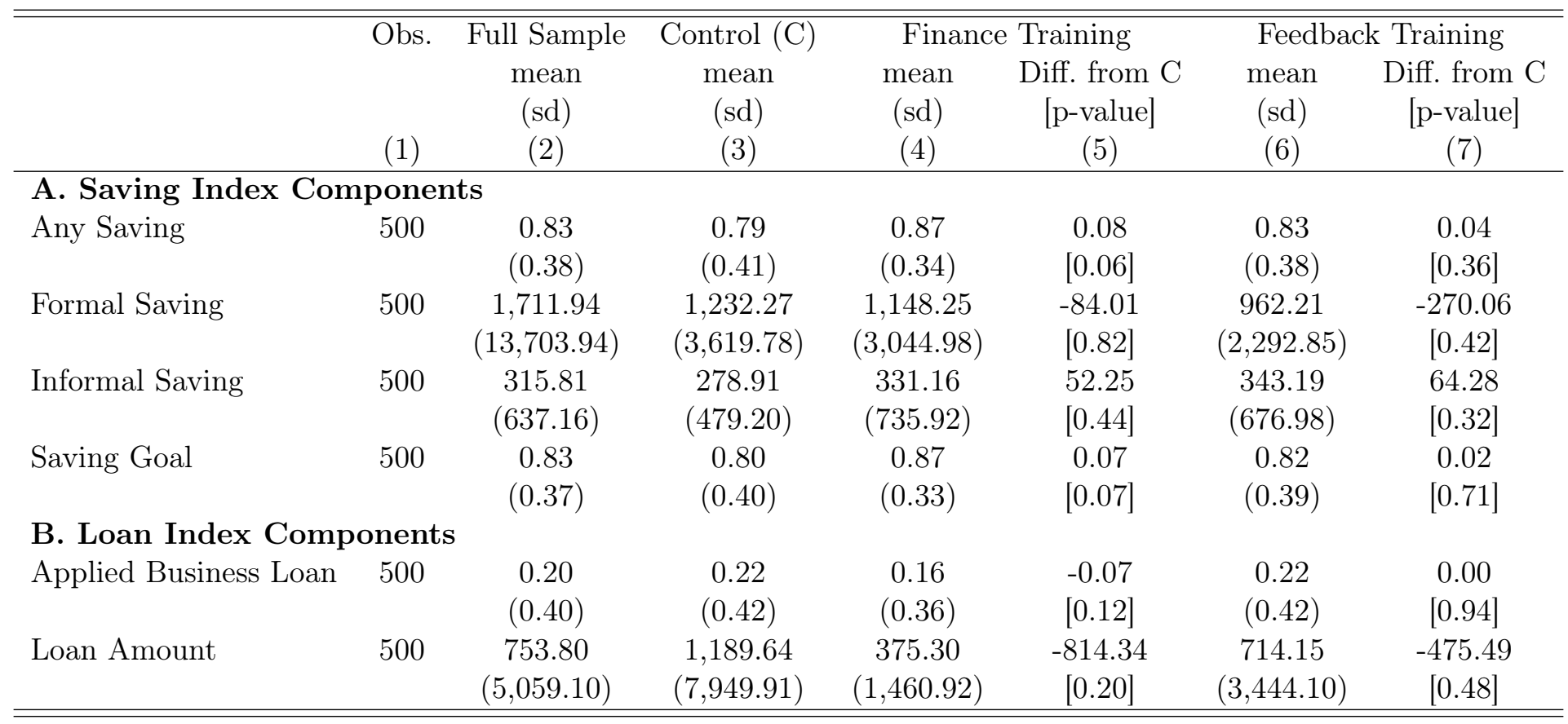

Source: Survey on micro and small enterprises in Uganda, wave October 2017, own calculations.

Notes: Standard deviations are in parenthesis, p-values for differences of means appear in squared brackets. The table provides summary statistics of baseline data and mean comparisons between finance training and control group (column (5)) and personalized feedback and control group (column (7)). 
Table A.13: Robustness Analysis: Intention-to-Treat Effects

\begin{tabular}{|c|c|c|c|c|c|}
\hline & $\begin{array}{c}\text { Investment } \\
\text { Index } \\
(1)\end{array}$ & $\begin{array}{c}\text { Saving } \\
\text { Index } \\
(2)\end{array}$ & $\begin{array}{l}\text { Profit } \\
\text { Index } \\
(3)\end{array}$ & $\begin{array}{l}\text { Loan } \\
\text { Index } \\
(4)\end{array}$ & $\begin{array}{c}\text { Overall } \\
\text { Index } \\
(5)\end{array}$ \\
\hline \multicolumn{6}{|c|}{$\begin{array}{l}\text { Panel A: 6-months follow-up results } \\
\text { Controlling for unbalanced Baseline Variables }\end{array}$} \\
\hline Finance Training & $\begin{array}{l}0.134 \\
(0.118)\end{array}$ & $\begin{array}{l}0.031 \\
(0.118)\end{array}$ & $\begin{array}{l}0.086 \\
(0.126)\end{array}$ & $\begin{array}{l}-.056 \\
(0.11)\end{array}$ & $\begin{array}{l}0.098 \\
(0.112)\end{array}$ \\
\hline Feedback Training & $\begin{array}{c}0.197^{*} \\
(0.114)\end{array}$ & $\begin{array}{c}0.258^{* *} \\
(0.114)\end{array}$ & $\begin{array}{l}0.233 \\
(0.146)\end{array}$ & $\begin{array}{l}-.058 \\
(0.102)\end{array}$ & $\begin{array}{c}0.263^{* *} \\
(0.113)\end{array}$ \\
\hline Any Saving $t-1$ & $\begin{array}{l}0.103 \\
(0.125)\end{array}$ & $\begin{array}{r}-.203 \\
(0.19)\end{array}$ & $\begin{array}{l}0.099 \\
(0.163)\end{array}$ & $\begin{array}{l}-.014 \\
(0.113)\end{array}$ & $\begin{array}{l}-.110 \\
(0.152)\end{array}$ \\
\hline Saving Goal ${ }_{t-1}$ & $\begin{array}{c}-.282^{*} \\
(0.146)\end{array}$ & $\begin{array}{l}-.156 \\
(0.154)\end{array}$ & $\begin{array}{r}-.028 \\
(0.21)\end{array}$ & $\begin{array}{l}0.141 \\
(0.101)\end{array}$ & $\begin{array}{c}-.337^{* *} \\
(0.156)\end{array}$ \\
\hline Applied for Business $\operatorname{Loan}_{t-1}$ & $\begin{array}{l}0.048 \\
(0.115)\end{array}$ & $\begin{array}{l}-.008 \\
(0.103)\end{array}$ & $\begin{array}{c}0.526^{* * *} \\
(0.198)\end{array}$ & $\begin{array}{c}-1.242^{* * *} \\
(0.378)\end{array}$ & $\begin{array}{l}-.069 \\
(0.137)\end{array}$ \\
\hline$\beta_{1}-\beta_{2}=0(\mathrm{p} \text {-value })^{a}$ & 0.60 & 0.08 & 0.36 & 0.99 & 0.18 \\
\hline $\mathrm{R}^{2}$ & 0.10 & 0.14 & 0.22 & 0.34 & 0.28 \\
\hline Mean (SD) of & 0.00 & 0.00 & 0.00 & 0.00 & 0.00 \\
\hline control group & $(1.00)$ & $(1.00)$ & $(1.00)$ & $(1.00)$ & $(1.00)$ \\
\hline Observations & 460 & 460 & 441 & 460 & 441 \\
\hline control for $y_{t-1}$ & yes & yes & yes & yes & yes \\
\hline control for industry strata & yes & yes & yes & yes & yes \\
\hline \multicolumn{6}{|c|}{$\begin{array}{l}\text { Panel B: 6-months follow-up results } \\
\text { Controlling for unbalanced Baseline Indices }\end{array}$} \\
\hline Finance Training & $\begin{array}{l}0.112 \\
(0.118)\end{array}$ & $\begin{array}{l}0.022 \\
(0.118)\end{array}$ & $\begin{array}{l}0.053 \\
(0.125)\end{array}$ & $\begin{array}{l}-.019 \\
(0.113)\end{array}$ & $\begin{array}{c}0.09 \\
(0.113)\end{array}$ \\
\hline Feedback Training & $\begin{array}{c}0.195^{*} \\
(0.115)\end{array}$ & $\begin{array}{c}0.257^{* *} \\
(0.114)\end{array}$ & $\begin{array}{l}0.217 \\
(0.145)\end{array}$ & $\begin{aligned}-.039 \\
(0.11)\end{aligned}$ & $\begin{array}{c}0.258^{* *} \\
(0.113)\end{array}$ \\
\hline Saving Index ${ }_{t-1}$ & $\begin{array}{l}0.028 \\
(0.051)\end{array}$ & $\begin{array}{c}0.406^{* * *} \\
(0.059)\end{array}$ & $\begin{array}{c}0.161^{* *} \\
(0.075)\end{array}$ & $\begin{array}{l}0.017 \\
(0.043)\end{array}$ & $\begin{array}{l}0.012 \\
(0.083)\end{array}$ \\
\hline Business Loan Index ${ }_{t-1}$ & $\begin{array}{l}0.003 \\
(0.039)\end{array}$ & $\begin{array}{l}0.004 \\
(0.029)\end{array}$ & $\begin{array}{c}0.206^{* *} \\
(0.089)\end{array}$ & $\begin{array}{c}0.512^{* * *} \\
(0.17)\end{array}$ & $\begin{array}{l}0.093 \\
(0.087)\end{array}$ \\
\hline$\beta_{1}-\beta_{2}=0(\mathrm{p} \text {-value })^{a}$ & 0.49 & 0.07 & 0.31 & 0.84 & 0.17 \\
\hline $\mathrm{R}^{2}$ & 0.10 & 0.14 & 0.23 & 0.26 & 0.28 \\
\hline Mean (SD) of & 0.00 & 0.00 & 0.00 & 0.00 & 0.00 \\
\hline control group & $(1.00)$ & $(1.00)$ & $(1.00)$ & $(1.00)$ & $(1.00)$ \\
\hline Observations & 460 & 460 & 441 & 460 & 441 \\
\hline control for $y_{t-1}$ & yes & yes & yes & yes & yes \\
\hline control for industry strata & yes & yes & yes & yes & yes \\
\hline
\end{tabular}

Source: Survey on micro and small enterprises in Uganda, waves October 2017, and April 2018, own calculations.

Notes: The table provides a robustness analysis on the short-term intention-to-treat effects of treatment assignment on primary outcome indices by controlling for unbalances at baseline. Panel A controls for unbalanced variables and panel B controls for unbalanced indices. Standard errors in parentheses. ${ }^{*} p<0.1,{ }^{* *} p<0.05,{ }^{* * *} p<0.01$.

${ }^{a}$ Test for equality of estimated coefficients of being assigned to finance and feedback training. Coefficients refer to equation (1). 
Table A.14: Robustness Analysis: Intention-to-Treat Effects: Controlling for the Share of Treated (10m Radius)

\begin{tabular}{lccccc}
\hline \hline & $\begin{array}{c}\text { Investment } \\
\text { Index } \\
(1)\end{array}$ & $\begin{array}{c}\text { Saving } \\
\text { Index } \\
(2)\end{array}$ & $\begin{array}{c}\text { Profit } \\
\text { Index } \\
(3)\end{array}$ & $\begin{array}{c}\text { Loan } \\
\text { Index } \\
(4)\end{array}$ & $\begin{array}{c}\text { Overall } \\
\text { Index } \\
(5)\end{array}$ \\
\hline Finance Training & 0.128 & -.008 & 0.097 & -.029 & 0.067 \\
& $(0.125)$ & $(0.13)$ & $(0.126)$ & $(0.116)$ & $(0.117)$ \\
Feedback Training & $0.232^{*}$ & $0.281^{* *}$ & 0.163 & -.031 & $0.258^{* *}$ \\
& $(0.119)$ & $(0.118)$ & $(0.139)$ & $(0.118)$ & $(0.115)$ \\
Finance Training * Share treated in 10m radius & -2.155 & 4.458 & -7.701 & 1.589 & 0.171 \\
& $(4.430)$ & $(6.672)$ & $(8.542)$ & $(3.896)$ & $(4.637)$ \\
Feedback Training * Share treated in 10m radius & -4.920 & -1.961 & 7.502 & -1.165 & -.103 \\
& $(4.445)$ & $(7.656)$ & $(9.400)$ & $(3.005)$ & $(5.811)$ \\
Share treated in 10m radius & 2.181 & -2.385 & 4.567 & 1.035 & 0.389 \\
& $(3.986)$ & $(6.425)$ & $(6.325)$ & $(2.898)$ & $(3.544)$ \\
Obs. & 460 & 460 & 441 & 460 & 441 \\
\hline \hline
\end{tabular}

Source: Survey on micro and small enterprises in Uganda, waves October 2017, and April 2018, own calculations.

Notes: The table provides a robustness analysis on the short-term intention-to-treat effects of treatment assignment on primary outcome indices by controlling for the share of treated within a $10 \mathrm{~m}$ radius. ${ }^{*} p<0.1$, ${ }^{* *} p<0.05,{ }^{* * *} p<0.01$.

Table A.15: Robustness Analysis: Intention-to-Treat Effects: Controlling for the Share of Treated (25m Radius)

\begin{tabular}{|c|c|c|c|c|c|}
\hline & $\begin{array}{l}\text { Investment } \\
\text { Index } \\
(1)\end{array}$ & $\begin{array}{c}\text { Saving } \\
\text { Index } \\
(2)\end{array}$ & $\begin{array}{c}\text { Profit } \\
\text { Index } \\
(3)\end{array}$ & $\begin{array}{c}\text { Loan } \\
\text { Index } \\
(4)\end{array}$ & $\begin{array}{c}\text { Overall } \\
\text { Index } \\
(5)\end{array}$ \\
\hline Finance Training & $\begin{array}{c}0.1 \\
(0.132)\end{array}$ & $\begin{array}{l}-.035 \\
(0.144)\end{array}$ & $\begin{array}{l}0.114 \\
(0.139)\end{array}$ & $\begin{array}{l}-.027 \\
(0.121)\end{array}$ & $\begin{array}{l}0.072 \\
(0.126)\end{array}$ \\
\hline Feedback Training & $\begin{array}{l}0.211 \\
(0.128)\end{array}$ & $\begin{array}{c}0.229^{*} \\
(0.132)\end{array}$ & $\begin{array}{l}0.057 \\
(0.157)\end{array}$ & $\begin{array}{l}-.023 \\
(0.123)\end{array}$ & $\begin{array}{l}0.186 \\
(0.123)\end{array}$ \\
\hline Finance Training $*$ Share treated in $25 \mathrm{~m}$ radius & $\begin{array}{l}0.585 \\
(1.420)\end{array}$ & $\begin{array}{l}1.921 \\
(2.015)\end{array}$ & $\begin{array}{c}-1.866 \\
(2.566)\end{array}$ & $\begin{array}{l}0.376 \\
(1.401)\end{array}$ & $\begin{array}{l}-.052 \\
(1.293)\end{array}$ \\
\hline Feedback Training $*$ Share treated in $25 \mathrm{~m}$ radius & $\begin{array}{l}-.366 \\
(1.549)\end{array}$ & $\begin{array}{l}0.903 \\
(2.477)\end{array}$ & $\begin{array}{l}5.168 \\
(3.942)\end{array}$ & $\begin{array}{l}-.397 \\
(0.832)\end{array}$ & $\begin{array}{l}2.170 \\
(2.374)\end{array}$ \\
\hline Share treated in $25 \mathrm{~m}$ radius & $\begin{array}{l}-.420 \\
(1.031)\end{array}$ & $\begin{array}{c}-1.072 \\
(1.742)\end{array}$ & $\begin{array}{l}2.049 \\
(1.870)\end{array}$ & $\begin{array}{l}-.267 \\
(0.709)\end{array}$ & $\begin{array}{l}0.186 \\
(0.847)\end{array}$ \\
\hline Obs. & 460 & 460 & 441 & 460 & 441 \\
\hline
\end{tabular}

Source: Survey on micro and small enterprises in Uganda, waves October 2017, and April 2018 own calculations.

Notes: The table provides a robustness analysis on the short-term intention-to-treat effects of treatment assignment on primary outcome indices by controlling for the share of treated within a $25 \mathrm{~m}$ radius. Standard errors in parentheses. ${ }^{*} p<0.1,{ }^{* *} p<0.05,{ }^{* * *} p<0.01$. 
Table A.16: Robustness Analysis: Intention-to-Treat Effects: Controlling for the Share of Treated (75m Radius)

\begin{tabular}{|c|c|c|c|c|c|}
\hline & $\begin{array}{l}\text { Investment } \\
\text { Index } \\
(1) \\
\end{array}$ & $\begin{array}{c}\text { Saving } \\
\text { Index } \\
(2) \\
\end{array}$ & $\begin{array}{c}\text { Profit } \\
\text { Index } \\
(3) \\
\end{array}$ & $\begin{array}{l}\text { Loan } \\
\text { Index } \\
(4) \\
\end{array}$ & $\begin{array}{c}\text { Overall } \\
\text { Index } \\
(5)\end{array}$ \\
\hline Finance Training & $\begin{array}{l}0.089 \\
(0.151)\end{array}$ & $\begin{array}{l}0.094 \\
(0.178)\end{array}$ & $\begin{array}{l}0.164 \\
(0.162)\end{array}$ & $\begin{array}{l}0.006 \\
(0.148)\end{array}$ & $\begin{array}{l}0.161 \\
(0.154)\end{array}$ \\
\hline Feedback Training & $\begin{array}{c}0.23 \\
(0.153)\end{array}$ & $\begin{array}{c}0.325^{* *} \\
(0.159)\end{array}$ & $\begin{array}{l}0.075 \\
(0.187)\end{array}$ & $\begin{array}{l}-.078 \\
(0.136)\end{array}$ & $\begin{array}{l}0.197 \\
(0.147)\end{array}$ \\
\hline Finance Training $*$ Share treated in $75 \mathrm{~m}$ radius & $\begin{array}{l}0.314 \\
(0.801)\end{array}$ & $\begin{array}{l}-.534 \\
(0.896)\end{array}$ & $\begin{array}{l}-.916 \\
(1.136)\end{array}$ & $\begin{array}{l}-.256 \\
(0.755)\end{array}$ & $\begin{array}{l}-.826 \\
(0.754)\end{array}$ \\
\hline Feedback Training $*$ Share treated in $75 \mathrm{~m}$ radius & $\begin{array}{c}-.305 \\
(0.77)\end{array}$ & $\begin{array}{l}-.515 \\
(0.991)\end{array}$ & $\begin{array}{l}1.681 \\
(1.718)\end{array}$ & $\begin{array}{l}0.372 \\
(0.732)\end{array}$ & $\begin{array}{l}0.678 \\
(1.138)\end{array}$ \\
\hline Share treated in $75 \mathrm{~m}$ radius & $\begin{array}{l}-.012 \\
(0.444)\end{array}$ & $\begin{array}{c}0.61 \\
(0.652)\end{array}$ & $\begin{array}{c}0.78 \\
(0.657)\end{array}$ & $\begin{array}{l}-.044 \\
(0.388)\end{array}$ & $\begin{array}{l}0.454 \\
(0.429)\end{array}$ \\
\hline Obs. & 460 & 460 & 441 & 460 & 441 \\
\hline
\end{tabular}

Source: Survey on micro and small enterprises in Uganda, waves October 2017, and April 2018, own calculations.

Notes: The table provides a robustness analysis on the short-term intention-to-treat effects of treatment assignment on primary outcome indices by controlling for the share of treated within a $75 \mathrm{~m}$ radius.Standard errors in parentheses. ${ }^{*} p<0.1,{ }^{* *} p<0.05,{ }^{* * *} p<0.01$.

Table A.17: Robustness Analysis: Intention-to-Treat Effects: Controlling for the Share of Treated (100m Radius)

\begin{tabular}{lccccc}
\hline \hline & $\begin{array}{c}\text { Investment } \\
\text { Index } \\
(1)\end{array}$ & $\begin{array}{c}\text { Saving } \\
\text { Index } \\
(2)\end{array}$ & $\begin{array}{c}\text { Profit } \\
\text { Index } \\
(3)\end{array}$ & $\begin{array}{c}\text { Loan } \\
\text { Index } \\
(4)\end{array}$ & $\begin{array}{c}\text { Overall } \\
\text { Index } \\
(5)\end{array}$ \\
\hline Finance Training & 0.131 & 0.028 & 0.149 & 0.052 & 0.164 \\
& $(0.167)$ & $(0.192)$ & $(0.171)$ & $(0.152)$ & $(0.164)$ \\
Feedback Training & 0.233 & 0.279 & 0.078 & -.059 & 0.184 \\
& $(0.168)$ & $(0.174)$ & $(0.21)$ & $(0.138)$ & $(0.157)$ \\
Finance Training * Share treated in 100m radius & -.022 & 0.085 & -.447 & -.471 & -.552 \\
& $(0.745)$ & $(0.824)$ & $(0.959)$ & $(0.668)$ & $(0.725)$ \\
Feedback Training * Share treated in 100m radius & -.207 & -.106 & 1.129 & 0.164 & 0.557 \\
& $(0.719)$ & $(0.866)$ & $(1.389)$ & $(0.65)$ & $(0.966)$ \\
Share treated in 100m radius & 0.223 & 0.331 & $0.911^{*}$ & 0.19 & 0.57 \\
& $(0.442)$ & $(0.593)$ & $(0.552)$ & $(0.399)$ & $(0.442)$ \\
Obs. & 460 & 460 & 441 & 460 & 441 \\
\hline \hline
\end{tabular}

Source: Survey on micro and small enterprises in Uganda, waves October 2017, and April 2018, own calculations.

Notes: The table provides a robustness analysis on the short-term intention-to-treat effects of treatment assignment on primary outcome indices by controlling for the share of treated within a $100 \mathrm{~m}$ radius. Standard errors in parentheses. ${ }^{*} p<0.1,{ }^{* *} p<0.05,{ }^{* * *} p<0.01$. 


\section{B Appendix B}

Table B.1: Intention-to-Treat Effects on Secondary Outcome Indices

\begin{tabular}{|c|c|c|c|c|c|c|}
\hline & $\begin{array}{l}\text { Financial } \\
\text { Literacy } \\
\text { Index } \\
(1)\end{array}$ & $\begin{array}{c}\text { Financial } \\
\text { Awareness } \\
\text { Index } \\
(2)\end{array}$ & $\begin{array}{c}\text { Financial attitudes } \\
\text { and Perceptions } \\
\text { Index } \\
(3)\end{array}$ & $\begin{array}{c}\text { Financial } \\
\text { Planning } \\
\text { Index } \\
(4)\end{array}$ & $\begin{array}{l}\text { Separating } \\
\text { Finances } \\
\text { Index } \\
(5)\end{array}$ & $\begin{array}{l}\text { Financial } \\
\text { Reflection } \\
\text { Index } \\
(6)\end{array}$ \\
\hline \multicolumn{7}{|c|}{ Panel A: 6-months follow-up results } \\
\hline Finance Training & $\begin{array}{l}-.164 \\
(0.119)\end{array}$ & $\begin{array}{l}-.040 \\
(0.123)\end{array}$ & $\begin{array}{l}-.072 \\
(0.112)\end{array}$ & $\begin{array}{l}0.035 \\
(0.111)\end{array}$ & $\begin{array}{l}0.127 \\
(0.103)\end{array}$ & $\begin{array}{l}0.014 \\
(0.112)\end{array}$ \\
\hline Feedback Training & $\begin{array}{l}0.005 \\
(0.121)\end{array}$ & $\begin{array}{l}-.005 \\
(0.128)\end{array}$ & $\begin{array}{l}-.009 \\
(0.119)\end{array}$ & $\begin{array}{c}0.174^{*} \\
(0.097)\end{array}$ & $\begin{array}{l}-.028 \\
(0.113)\end{array}$ & $\begin{array}{c}-.003 \\
(0.12)\end{array}$ \\
\hline$\beta_{1}-\beta_{2}=0(\mathrm{p} \text {-value })^{a}$ & 0.16 & 0.80 & 0.59 & 0.13 & 0.13 & 0.88 \\
\hline $\mathrm{R}^{2}$ & 0.03 & 0.02 & 0.01 & 0.02 & 0.07 & 0.01 \\
\hline Mean (SD) of & 0.00 & 0.00 & 0.00 & 0.00 & 0.00 & 0.00 \\
\hline control group & $(1.00)$ & $(1.00)$ & $(1.00)$ & $(1.00)$ & $(1.00)$ & $(1.00)$ \\
\hline Observations & 457 & 460 & 459 & 447 & 446 & 444 \\
\hline control for $y_{t-1}$ & yes & yes & yes & yes & yes & yes \\
\hline control for industry strata & yes & yes & yes & yes & yes & yes \\
\hline \multicolumn{7}{|c|}{ Panel B: 12-months follow-up results } \\
\hline Finance Training & $\begin{array}{l}0.182 \\
(0.116)\end{array}$ & $\begin{array}{l}-.031 \\
(0.114)\end{array}$ & $\begin{array}{l}0.056 \\
(0.109)\end{array}$ & $\begin{array}{c}0.058 \\
(0.11)\end{array}$ & $\begin{array}{l}0.053 \\
(0.109)\end{array}$ & $\begin{array}{l}0.053 \\
(0.119)\end{array}$ \\
\hline Feedback Training & $\begin{array}{l}0.059 \\
(0.117)\end{array}$ & $\begin{array}{c}0.062 \\
(0.11)\end{array}$ & $\begin{array}{l}-.167 \\
(0.116)\end{array}$ & $\begin{array}{c}0.171^{*} \\
(0.102)\end{array}$ & $\begin{array}{l}-.013 \\
(0.113)\end{array}$ & $\begin{array}{l}-.135 \\
(0.127)\end{array}$ \\
\hline April 2018 treatment & $\begin{array}{c}0.09 \\
(0.095)\end{array}$ & $\begin{array}{l}-.008 \\
(0.089)\end{array}$ & $\begin{array}{l}0.029 \\
(0.091)\end{array}$ & $\begin{array}{l}-.077 \\
(0.084)\end{array}$ & $\begin{array}{l}-.085 \\
(0.089)\end{array}$ & $\begin{array}{l}0.009 \\
(0.102)\end{array}$ \\
\hline$\beta_{1}-\beta_{2}=0(\mathrm{p} \text {-value })^{a}$ & 0.29 & 0.37 & 0.04 & 0.24 & 0.53 & 0.14 \\
\hline $\mathrm{R}^{2}$ & 0.07 & 0.00 & 0.04 & 0.05 & 0.05 & 0.01 \\
\hline Mean (SD) of & 0.00 & 0.00 & 0.00 & 0.00 & 0.00 & 0.00 \\
\hline control group & $(1.00)$ & $(1.00)$ & $(1.00)$ & $(1.00)$ & $(1.00)$ & $(1.00)$ \\
\hline Observations & 451 & 454 & 453 & 441 & 440 & 438 \\
\hline control for $y_{t-1}$ & yes & yes & yes & yes & yes & yes \\
\hline control for industry strata & yes & yes & yes & yes & yes & yes \\
\hline
\end{tabular}

Source: Survey on micro and small enterprises in Uganda, waves October 2017, April 2018, and October 2018, own calculations.

Notes: The table shows intention-to-treat effects on the "financial literacy index" (column 1), "financial awareness index" (column 2), "financial attitudes and perceptions index" (column 3), "financial planning index" (column 4), "separating finances index" (column 5) and "financial reflecion index" (column 6). Panel A provides 6-months follow-up and Panel B provides 12-months follow-up results. Detailed intention-to-treat effects on variables belonging to the "financial literacy index" can be found in Table B.4 and B.5. on "financial awareness index" in Table B.6, on "financial attitudes and perceptions index" in Table B.7, on "financial planning index" in Table B.8, on "separating finances index' in Table B.9 and on "financial reflection index" in Table B.10. Standard errors in parentheses. Standard errors in parentheses. * $p<0.1,{ }^{* *} p<0.05,{ }^{* * *} p<0.01$.

${ }^{a}$ Test for equality of estimated coefficients of being assigned to finance and feedback training. Coefficients refer to equation (1). 


\begin{tabular}{|c|c|}
\hline Variable & Survey Question \\
\hline \multicolumn{2}{|c|}{ Financial Literacy Index } \\
\hline $\mathrm{s} 2^{a}$ & $\begin{array}{l}\text { Imagine that five brothers are given a gift of } 10,000,000 \text { UGX. If the brothers have to share the money } \\
\text { equally how much does each one get? }\end{array}$ \\
\hline $\mathrm{s} 3^{a}$ & $\begin{array}{l}\text { Imagine that you get a gift of } 300,000 \mathrm{UGX} \text {, and you put it at home for } 12 \text { months. Inflation stays at } \\
10 \% \text {. After one year, how much could you buy for this money? Answer options: A) More than I could } \\
\text { buy today, B) The same amount that I could buy today, C) Less than I could buy today }\end{array}$ \\
\hline $\mathrm{s} 4^{a}$ & $\begin{array}{l}\text { You lend 100,000 UGX to a friend one evening and he gives you 100,000 UGX back the next month. How } \\
\text { much interest has he paid on this loan? }\end{array}$ \\
\hline $\mathrm{s} 5 \mathrm{a}^{a}$ & $\begin{array}{l}\text { Suppose you put } 100,000 \text { UGX into a savings account with a guaranteed interest rate of } 2 \% \text { per year. You } \\
\text { do not have to pay fees, you don't make any further payments into this account and you don't withdraw } \\
\text { any money. How much would be in the account at the end of the first year, once the interest payment is } \\
\text { made? }\end{array}$ \\
\hline $\mathrm{s} 5 \mathrm{~b}^{a}$ & $\begin{array}{l}\text { [Conditional on Question s5a:] How much would be in the account at the end of five years? Answer } \\
\text { options: A) More than 110,000 UGX, B) Exactly 110,000 UGX, C) Less than 110,000 UGX }\end{array}$ \\
\hline $\mathrm{s} 6 \mathrm{a}^{a}$ & An investment with high return is likely to be of high risk. Answer options: A) True, B) False \\
\hline $\mathrm{s}_{6} \mathrm{~b}^{a}$ & High inflation means that the cost of living is increasing sharply. Answer options: A) True, B) False \\
\hline $\mathrm{s}_{6} \mathrm{c}^{a}$ & $\begin{array}{l}\text { It is less likely that you will lose all of your money if you save it in more than one place. Answer options: } \\
\text { A) True, B) False }\end{array}$ \\
\hline $\mathrm{s} 6 \mathrm{~d}^{a}$ & $\begin{array}{l}\text { A financial institution needs to get your agreement first before sharing your information with someone } \\
\text { else. Answer options: A) True, B) False }\end{array}$ \\
\hline $\mathrm{s} 7^{a}$ & $\begin{array}{l}\text { Imagine the same cell-phone is on sale in two different shops at } 200,000 \text { UGX and one shop offered a } \\
\text { discount of } 30,000 \text { UGX and the other shop offered a } 10 \% \text { discount: which one is the better bargain? }\end{array}$ \\
\hline $\mathrm{s} 21^{a}$ & $\begin{array}{l}\text { Imagine you want to buy a bag of rice for UGX } 3,700 \text {, but you only have a } 10,000 \text { note. How much change } \\
\text { do you get? }\end{array}$ \\
\hline $\mathrm{s} 22^{a}$ & $\begin{array}{l}\text { A second-hand dealer is selling a motorbike for UGX } 600,000 \text {. This is two thirds of the original price. } \\
\text { How much did the motorbike cost when new? }\end{array}$ \\
\hline \multicolumn{2}{|c|}{ Financial Awareness Index } \\
\hline $\mathrm{s} 30 \mathrm{a}^{a}$ & $\begin{array}{l}\text { Sarah is preparing a budget for her household. Which of the following needs to be included in the budget? } \\
\text { Answer options: A) Income only, B) Expenses only, C) Both }\end{array}$ \\
\hline $\mathrm{s}^{3} 0 \mathrm{c}^{a}$ & $\begin{array}{l}\text { Godfrey recently borrowed some money from a local moneylender. He wanted to buy some clothes for his } \\
\text { children for a festival. Do you think Godfrey's loan is productive? }\end{array}$ \\
\hline $\mathrm{s} 31 \mathrm{a}^{a}$ & $\begin{array}{l}\text { John does plastering on a tall building. It is a dangerous job and he is worried that if he gets injured } \\
\text { his family's income will become inadequate to meet their needs. If John comes to you for advice what } \\
\text { would you suggest? Answer options: A) Quit job, B) Purchase health/life/accident insurance, C) Increase } \\
\text { savings }\end{array}$ \\
\hline $\mathrm{s} 31 \mathrm{~b}^{a}$ & $\begin{array}{l}\text { Barbara has a very bright child who is currently in secondary school, but will probably do well in } \\
\text { university. She is worried how her family will pay for the child's education. If Barbara comes to you for } \\
\text { advice what would you suggest? Answer options: A) Buy child life insurance policy, B) Borrow money } \\
\text { from moneylender, C) Open savings account in a bank, D) Save at home, E) Discontinue education }\end{array}$ \\
\hline $\mathrm{s} 31 \mathrm{c}^{a}$ & $\begin{array}{l}\text { Bosco currently drives a rented bodaboda. He wants to purchase his own bodaboda but does not have } \\
\text { the money and is considering taking out a loan for the same. If Bosco comes to you for advice what will } \\
\text { you suggest- should he take out a loan? }\end{array}$ \\
\hline Financi & $\begin{array}{l}\text { Edward recently got married. He and his wife are considering buying a TV. They do not have enough } \\
\text { savings and will need to take out a loan. Edward has two options. What would you advise Edward and } \\
\text { his wife? Answer options: A) He can take a loan from the moneylender and a relative and get a bigger } \\
\text { amount in a loan to buy a big TV,B) He can take a loan only from a relative and buy a smaller TV } \\
\text { udes and Perceptions Index }\end{array}$ \\
\hline $\mathrm{r} 6 \mathrm{a}^{b}$ & $\begin{array}{l}\text { Machines and equipment held in my business are a good way of saving money so that others don't take } \\
\text { it. Answer options: A) Completely agree, B) Agree, C) Neutral (neither agree nor disagree), D) Disagree, } \\
\text { E) Completely disagree }\end{array}$ \\
\hline $\mathrm{r} 6 \mathrm{~b}^{b}$ & $\begin{array}{l}\text { I feel pressure to share extra business income with other household members. Answer options: A) Com- } \\
\text { pletely agree, B) Agree, C) Neutral (neither agree nor disagree), D) Disagree, E) Completely disagree }\end{array}$ \\
\hline $\mathrm{r} 6 \mathrm{f}^{b}$ & $\begin{array}{l}\text { I tend to live for today and let tomorrow take care of itself. Answer options: A) Completely agree, B) } \\
\text { Agree, C) Neutral (neither agree nor disagree), D) Disagree, E) Completely disagree }\end{array}$ \\
\hline $\mathrm{r} 8 \mathrm{~g}^{c}$ & $\begin{array}{l}\text { I continue to work on hard projects even when others oppose me. Possible answers: A) Does perfectly } \\
\text { apply to me, B) Does rather apply to me, C) In between, D) Does rather not apply to me, E) Does not } \\
\text { apply to me at all }\end{array}$ \\
\hline $\mathrm{r} 8 \mathrm{n}^{c}$ & $\begin{array}{l}\text { I never try anything that I am not sure of. Possible answers: A) Does perfectly apply to me, B) Does } \\
\text { rather apply to me, C) In between, D) Does rather not apply to me, E) Does not apply to me at all }\end{array}$ \\
\hline
\end{tabular}


Financial Plannung Index and Record Keeping

$\mathrm{j} 23 \mathrm{a} / \mathrm{j} 23 \mathrm{~b} / \mathrm{j}_{2} 3 \mathrm{c}^{d}$ Sometimes important things break that must be replaced. How do you plan and organize the replacement? Answers Options: A) I plan in advance before it actually breaks to save money for its replacement, B) In the moment it breaks I take care of the replacement. If I have money at hand, I replace it right away. If I don't have money at hand, I start saving for it and replace it later., C) I do nothing until I can really no longer go without it.

j6a $a^{a} \quad$ Do you keep financial records in your business? Possible answers: A) No, none, B) Yes, personal notes (order book, etc.), C) Yes, cash account book ("direct contributions"), D) Yes, full accounting (balance sheet and income statement), E) Yes, collection of information on sales and purchases on electronic device(s)

\section{Separating Finances Index}

j6c $\mathrm{c}^{e} \quad$ How often do you keep the accounts or books for your business and home separate? Answer options: A) Never, B) Rarely, C) Sometimes, D) Almost always

j6d $\quad$ How often do you keep cash for your business and home physically separated? Answer options: A) Never, B) Rarely, C) Sometimes, D) Almost always

$\mathrm{j} 6 \mathrm{e}^{e} \quad$ How often do you set money aside for your business but is gets used for household/private expenses? Answer options: A) Never, B) Rarely, C) Sometimes, D) Almost always

$\mathrm{J}_{27 \mathrm{c}^{e}} \quad$ If you take money out of your business (apart from the salary you take out) to pay household/private expenses, how often do you put it back? Answer options: A) Never, B) Rarely, C) Sometimes, D) Almost always

$\mathrm{j} 27 \mathrm{~d}^{e}$

If you take goods out of your business for your household/relatives/friends, does someone (you/relatives/friends) pay for it? Answer options: A) Never, B) Rarely, C) Sometimes, D) Almost always

a25a $\mathrm{a}^{e} \quad$ Writing down what you plan to do with your money for your family and household means you make a household budget. How often do you do that? Answer options: A) Never, B) Rarely, C) Sometimes, D) Almost always

Financial Reflection Index and Impulsiveness

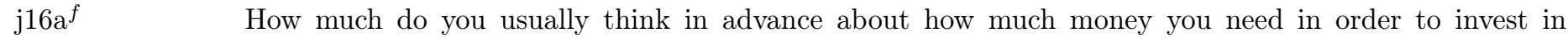
merchandise, business expenses and debt repayment for the upcoming month? Answer options: A) A lot, B) Some, C) A little, D) Hardly at all

$\mathrm{j} 16 \mathrm{~b}^{f} \quad$ How much have you thought about retirement? Answer options: A) A lot, B) Some, C) A little, D) Hardly at all

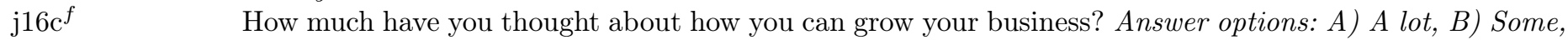
C) A little, D) Hardly at all

$\mathrm{j} 16 \mathrm{~d}^{f} \quad$ How much have you thought about investing in your business? Answer options: A) A lot, B) Some, C) A little, D) Hardly at all

$\mathrm{r} 8 \mathrm{~s}^{g} \quad$ I am impulsive and tend to buy things even when I can't really afford them Possible answers: A) Does perfectly apply to me, B) Does rather apply to me, C) In between, D) Does rather not apply to me, E) Does not apply to me at all

${ }^{a}$ Outcome variable is dichotomous, which is either $1=$ correct answer, $0=$ wrong answer or $1=$ yes, $0=$ no

${ }^{b}$ Outcome variable is coded as follows, where $1=$ Completely agree, $2=$ Agree, $3=$ Neutral (neither agree nor disagree), $4=$ Disagree, $5=$ Completely disagree.

${ }^{c}$ Outcome variable is coded as follows, where $1=$ Does perfectly apply to me, $2=$ Does rather apply to me, $3=$ In between, $4=$ Does rather not apply to me, $5=$ Does not apply to me at all.

${ }^{d}$ Outcome variables are coded as follows: variable $\mathrm{j} 23 \mathrm{a}=1$ if answer option $=\mathrm{A}$ and $\mathrm{j} 23 \mathrm{a}=0$ if answer option otherwise; variable $\mathrm{j} 23 \mathrm{~b}=1$ if answer option $=\mathrm{B}$ and $\mathrm{j} 23 \mathrm{c}=0$ if answer option otherwise; variable $\mathrm{j} 23 \mathrm{c}=1$ if answer option $=\mathrm{C}$ and $\mathrm{j} 23 \mathrm{c}=0$ if answer option otherwise.

e Outcome variable is dichotomous, where $1=$ Sometimes, always always, $0=$ never, rarely

${ }^{f}$ Outcome variable is coded as follows: $1=$ Hardly at all, $2=\mathrm{A}$ little, $3=$ Some, $4=\mathrm{A}$ lot

$g$ Outcome variable is coded as follows: $1=$ Does perfectly apply to me, $2=$ Does rather apply to me, $3=$ In between, $4=$ Does rather not apply to me, $5=$ Does not apply to me at all 
Table B.3: Pre-Intervention Descriptive Statistics of Secondary Outcomes Indices

\begin{tabular}{|c|c|c|c|c|c|c|c|}
\hline & $\begin{array}{l}\text { Obs. } \\
(1) \\
\end{array}$ & $\begin{array}{c}\text { Full Sample } \\
\text { mean } \\
(\mathrm{sd}) \\
(2) \\
\end{array}$ & $\begin{array}{c}\text { Control }(\mathrm{C}) \\
\text { mean } \\
(\mathrm{sd}) \\
(3) \\
\end{array}$ & $\begin{array}{c}\text { Finar } \\
\text { mean } \\
(\mathrm{sd}) \\
(4)\end{array}$ & $\begin{array}{l}\text { ce Training } \\
\text { Diff. from C } \\
\text { [p-value] } \\
(5)\end{array}$ & $\begin{array}{c}\text { Feedl } \\
\text { mean } \\
(\mathrm{sd}) \\
(6) \\
\end{array}$ & $\begin{array}{c}\text { ack Training } \\
\text { Diff. from C } \\
\text { [p-value] } \\
(7)\end{array}$ \\
\hline Financial Literacy Index & 457 & $\begin{array}{l}-0.08 \\
(1.12)\end{array}$ & $\begin{array}{c}0.00 \\
(1.00)\end{array}$ & $\begin{array}{c}-0.13 \\
(1.13)\end{array}$ & $\begin{array}{l}-0.13 \\
{[0.31]}\end{array}$ & $\begin{array}{c}-0.12 \\
(1.21)\end{array}$ & $\begin{array}{l}-0.12 \\
{[0.37]}\end{array}$ \\
\hline Financial Awareness Index & 460 & $\begin{array}{l}-0.06 \\
(0.94)\end{array}$ & $\begin{array}{c}0.00 \\
(1.00)\end{array}$ & $\begin{array}{l}-0.14 \\
(0.94)\end{array}$ & $\begin{array}{l}-0.14 \\
{[0.21]}\end{array}$ & $\begin{array}{l}-0.04 \\
(0.87)\end{array}$ & $\begin{array}{l}-0.04 \\
{[0.68]}\end{array}$ \\
\hline Financial Attitudes and Perceptions Index & 459 & $\begin{array}{l}-0.08 \\
(1.04)\end{array}$ & $\begin{array}{c}0.00 \\
(1.00)\end{array}$ & $\begin{array}{c}-0.13 \\
(1.06)\end{array}$ & $\begin{array}{l}-0.13 \\
{[0.28]}\end{array}$ & $\begin{array}{l}-0.12 \\
(1.07)\end{array}$ & $\begin{array}{l}-0.12 \\
{[0.31]}\end{array}$ \\
\hline Financial Planning Index & 447 & $\begin{array}{c}0.02 \\
(0.96)\end{array}$ & $\begin{array}{c}0.00 \\
(1.00)\end{array}$ & $\begin{array}{c}0.01 \\
(0.98)\end{array}$ & $\begin{array}{c}0.01 \\
{[0.94]}\end{array}$ & $\begin{array}{c}0.05 \\
(0.91)\end{array}$ & $\begin{array}{c}0.05 \\
{[0.66]}\end{array}$ \\
\hline Separating Finances Index & 446 & $\begin{array}{l}-0.05 \\
(1.04)\end{array}$ & $\begin{array}{c}0.00 \\
(1.00)\end{array}$ & $\begin{array}{c}-0.04 \\
(0.99)\end{array}$ & $\begin{array}{l}-0.04 \\
{[0.72]}\end{array}$ & $\begin{array}{l}-0.11 \\
(1.12)\end{array}$ & $\begin{array}{l}-0.11 \\
{[0.38]}\end{array}$ \\
\hline Financial Reflection Index & 444 & $\begin{array}{l}-0.06 \\
(0.96)\end{array}$ & $\begin{array}{c}0.00 \\
(1.00)\end{array}$ & $\begin{array}{c}-0.06 \\
(0.94)\end{array}$ & $\begin{array}{l}-0.06 \\
{[0.58]}\end{array}$ & $\begin{array}{l}-0.10 \\
(0.95)\end{array}$ & $\begin{array}{l}-0.10 \\
{[0.37]}\end{array}$ \\
\hline F-statistic joint orthogonality & & & & & 0.98 & & 0.32 \\
\hline
\end{tabular}

Source: Survey on micro and small enterprises in Uganda, wave October 2017, own calculations.

Notes: The table provides summary statistics of baseline data and mean comparisons between finance training and control group (column (5)) and personalized feedback and control group (column (7)). Standard deviations are in parenthesis, p-values for differences of means appear in squared brackets. 
Table B.4: Intention-to-Treat Effects on Financial Literacy Index Components (I/II)

\begin{tabular}{|c|c|c|c|c|c|c|c|}
\hline & $\begin{array}{c}\text { Financial Literacy } \\
\text { Index } \\
(1)\end{array}$ & $\begin{array}{l}\mathrm{s} 2 \\
(2)\end{array}$ & $\begin{array}{l}\mathrm{s} 3 \\
(3)\end{array}$ & $\begin{array}{l}\mathrm{s} 4 \\
(4)\end{array}$ & $\begin{array}{l}\mathrm{s} 5 \mathrm{a} \\
(5)\end{array}$ & $\begin{array}{l}\mathrm{s} 5 \mathrm{~b} \\
(6)\end{array}$ & $\begin{array}{l}\text { s6a } \\
(7)\end{array}$ \\
\hline \multicolumn{8}{|c|}{ Panel A: 6-months follow-up results } \\
\hline Finance Training & $\begin{array}{l}-.164 \\
(0.119)\end{array}$ & $\begin{array}{l}-.009 \\
(0.022)\end{array}$ & $\begin{array}{c}-.105^{* *} \\
(0.053)\end{array}$ & $\begin{array}{l}0.008 \\
(0.017)\end{array}$ & $\begin{array}{l}-.045 \\
(0.054)\end{array}$ & $\begin{array}{l}-.005 \\
(0.051)\end{array}$ & $\begin{array}{r}-.016 \\
(0.04)\end{array}$ \\
\hline Feedback Training & $\begin{array}{l}0.005 \\
(0.121)\end{array}$ & $\begin{array}{l}-.018 \\
(0.022)\end{array}$ & $\begin{array}{l}-.029 \\
(0.051)\end{array}$ & $\begin{array}{l}0.014 \\
(0.016)\end{array}$ & $\begin{array}{c}0.05 \\
(0.056)\end{array}$ & $\begin{array}{l}0.014 \\
(0.051)\end{array}$ & $\begin{array}{c}0.01 \\
(0.039)\end{array}$ \\
\hline$\beta_{1}-\beta_{2}=0(\mathrm{p} \text {-value })^{a}$ & 0.16 & 0.70 & 0.15 & 0.69 & 0.08 & 0.70 & 0.50 \\
\hline $\mathrm{R} 2$ & 0.03 & 0.10 & 0.01 & 0.00 & 0.07 & 0.05 & 0.03 \\
\hline Mean (SD) of & 0.00 & 0.96 & 0.78 & 0.98 & 0.41 & 0.65 & 0.83 \\
\hline control group & 1.00 & 0.19 & 0.42 & 0.15 & 0.49 & 0.48 & 0.37 \\
\hline Observations & 457 & 459 & 457 & 460 & 458 & 458 & 458 \\
\hline control for $y_{t-1}$ & yes & yes & yes & yes & yes & yes & yes \\
\hline control for industry strata & yes & yes & yes & yes & yes & yes & yes \\
\hline \multicolumn{8}{|c|}{ Panel B: 12-months follow-up results } \\
\hline Finance Training & $\begin{array}{l}0.182 \\
(0.116)\end{array}$ & $\begin{array}{l}-.016 \\
(0.019)\end{array}$ & $\begin{array}{l}0.021 \\
(0.051)\end{array}$ & $\begin{array}{l}0.008 \\
(0.012)\end{array}$ & $\begin{array}{l}0.045 \\
(0.056)\end{array}$ & $\begin{array}{l}0.048 \\
(0.052)\end{array}$ & $\begin{array}{c}0.071^{* *} \\
(0.034)\end{array}$ \\
\hline Feedback Training & $\begin{array}{l}0.059 \\
(0.117)\end{array}$ & $\begin{array}{l}-.035 \\
(0.022)\end{array}$ & $\begin{array}{l}0.013 \\
(0.052)\end{array}$ & $\begin{array}{l}0.008 \\
(0.012)\end{array}$ & $\begin{array}{l}-.045 \\
(0.057)\end{array}$ & $\begin{array}{l}-.013 \\
(0.054)\end{array}$ & $\begin{array}{l}0.028 \\
(0.037)\end{array}$ \\
\hline April 2018 treatment & $\begin{array}{c}0.09 \\
(0.095)\end{array}$ & $\begin{array}{c}0.033^{*} \\
(0.018)\end{array}$ & $\begin{array}{l}-.011 \\
(0.042)\end{array}$ & $\begin{array}{l}0.008 \\
(0.009)\end{array}$ & $\begin{array}{l}-.011 \\
(0.046)\end{array}$ & $\begin{array}{l}-.002 \\
(0.043)\end{array}$ & $\begin{array}{l}0.009 \\
(0.028)\end{array}$ \\
\hline$\beta_{1}-\beta_{2}=0(\mathrm{p} \text {-value })^{a}$ & 0.29 & 0.43 & 0.87 & 0.99 & 0.11 & 0.24 & 0.17 \\
\hline $\mathrm{R}^{2}$ & 0.07 & 0.05 & 0.01 & 0.01 & 0.04 & 0.01 & 0.03 \\
\hline Mean(SD)of & 0.00 & 0.97 & 0.76 & 0.98 & 0.47 & 0.66 & 0.85 \\
\hline controlgroup & 1.00 & 0.18 & 0.43 & 0.14 & 0.50 & 0.47 & 0.36 \\
\hline Observations & 451 & 453 & 451 & 454 & 452 & 452 & 452 \\
\hline control for $y_{t-1}$ & yes & yes & yes & yes & yes & yes & yes \\
\hline control for industry strata & yes & yes & yes & yes & yes & yes & yes \\
\hline
\end{tabular}

Source: Survey on micro and small enterprises in Uganda, waves October 2017, April 2018, and October 2018, own calculations.

Notes: The table shows intention-to-treat effects on variables belonging to the financial literacy index. All outcome variables are described in Table B.2. Standard errors in parentheses. ${ }^{*} p<0.1,{ }^{* *} p<0.05,{ }^{* * *}$ $p<0.01$.

${ }^{a}$ Test for equality of estimated coefficients of being assigned to finance and feedback training. Coefficients refer to equation (1). 
Table B.5: Intention-to-Treat Effects on Financial Literacy Components (II/II)

\begin{tabular}{|c|c|c|c|c|c|c|}
\hline & $\begin{array}{l}\mathrm{s} 6 \mathrm{~b} \\
(1)\end{array}$ & $\begin{array}{l}\text { s6c } \\
(2)\end{array}$ & $\begin{array}{l}\text { s6d } \\
(3)\end{array}$ & $\begin{array}{r}\text { s7 } \\
(4)\end{array}$ & $\begin{array}{l}\text { s21 } \\
(5)\end{array}$ & $\begin{array}{l}\text { s22 } \\
(6)\end{array}$ \\
\hline \multicolumn{7}{|c|}{ Panel A: 6-months follow-up results } \\
\hline Finance Training & $\begin{array}{l}0.015 \\
(0.013)\end{array}$ & $\begin{array}{l}-.051 \\
(0.04)\end{array}$ & $\begin{array}{l}-.003 \\
(0.022)\end{array}$ & $\begin{array}{l}-.056 \\
(0.046)\end{array}$ & $\begin{array}{l}-.013 \\
(0.023)\end{array}$ & $\begin{array}{l}-.034 \\
(0.047)\end{array}$ \\
\hline Feedback Training & $\begin{array}{l}-.012 \\
(0.018)\end{array}$ & $\begin{array}{l}-.019 \\
(0.038)\end{array}$ & $\begin{array}{l}0.002 \\
(0.02)\end{array}$ & $\begin{array}{l}-.016 \\
(0.045)\end{array}$ & $\begin{array}{c}0.0004 \\
(0.022)\end{array}$ & $\begin{array}{c}0.031 \\
(0.05)\end{array}$ \\
\hline$\beta_{1}-\beta_{2}=0(\mathrm{p} \text {-value })^{a}$ & 0.10 & 0.43 & 0.81 & 0.39 & 0.57 & 0.18 \\
\hline $\mathrm{R}^{2}$ & 0.01 & 0.01 & 0.01 & 0.02 & 0.02 & 0.05 \\
\hline Mean $(\mathrm{SD})$ of & 0.97 & 0.89 & 0. & 0.82 & 0.94 & 0.22 \\
\hline control group & $(0.17)$ & $(0.31)$ & $(0.15)$ & $(0.39)$ & $(0.24)$ & $(0.42)$ \\
\hline Observations & 459 & 459 & 45 ! & 459 & 460 & 460 \\
\hline r $y_{t-1}$ & yes & yes & yes & yes & yes & yes \\
\hline control for industry strata & yes & yes & yes & yes & yes & yes \\
\hline \multicolumn{7}{|c|}{ Panel B: 12-months follow-up results } \\
\hline Finance Training & $\begin{array}{l}-.023 \\
(0.022)\end{array}$ & $\begin{array}{l}0.018 \\
(0.031)\end{array}$ & $\begin{array}{l}0.002 \\
(0.027)\end{array}$ & $\begin{array}{l}0.004 \\
(0.037)\end{array}$ & $\begin{array}{l}0.013 \\
(0.013)\end{array}$ & $\begin{array}{l}0.074 \\
(0.048)\end{array}$ \\
\hline Feedback Trail & $\begin{array}{l}0.002 \\
(0.019)\end{array}$ & $\begin{array}{l}-.003 \\
(0.033)\end{array}$ & $\begin{array}{l}0.031 \\
(0.023)\end{array}$ & $\begin{array}{l}0.013 \\
(0.037)\end{array}$ & $\begin{array}{c}-.00003 \\
(0.016)\end{array}$ & $\begin{array}{c}0.06 \\
(0.048)\end{array}$ \\
\hline April 2018 tre & $\begin{array}{l}0.007 \\
(0.018)\end{array}$ & $\begin{array}{l}0.001 \\
(0.025)\end{array}$ & $\begin{array}{l}-.005 \\
(0.019)\end{array}$ & $\begin{array}{c}0.034 \\
(0.03)\end{array}$ & $\begin{array}{l}-.014 \\
(0.012)\end{array}$ & $\begin{array}{c}0.035 \\
(0.04)\end{array}$ \\
\hline$\beta_{1}-\beta_{2}=0(\mathrm{p} \text {-value })^{a}$ & 0.26 & 0.50 & 0.21 & 0.81 & 0.32 & 0.78 \\
\hline $\mathrm{R}^{2}$ & 0.01 & 0.01 & & 0.01 & 0.03 & 0.04 \\
\hline Mean & 0.97 & 0.90 & 0.97 & 0.84 & 0.95 & 0.21 \\
\hline & $(0.17)$ & $(0.30)$ & $(0.18)$ & $(0.37)$ & $(0.22)$ & $(0.41)$ \\
\hline Observations & 453 & 453 & 453 & 453 & 454 & 454 \\
\hline con & yes & yes & yes & yes & yes & yes \\
\hline control for industry strata & yes & yes & yes & yes & yes & yes \\
\hline
\end{tabular}

Source: Survey on micro and small enterprises in Uganda, waves October 2017, April 2018, and October 2018, own calculations.

Notes: The table shows intention-to-treat effects on variables belonging to the financial literacy index. All outcome variables are described in Table B.2. Standard errors in parentheses. ${ }^{*} p<0.1,{ }^{* *} p<0.05,{ }^{* * *} p<0.01$.

${ }^{a}$ Test for equality of estimated coefficients of being assigned to finance and feedback training. Coefficients refer to equation (1). 
Table B.6: Intention-to-Treat Effects on Financial Awareness Index Components

\begin{tabular}{|c|c|c|c|c|c|c|c|}
\hline & $\begin{array}{c}\text { Financial Awareness } \\
\text { Index } \\
(1)\end{array}$ & $\begin{array}{l}\text { s30a } \\
(2)\end{array}$ & $\begin{array}{l}\text { s30c } \\
(3)\end{array}$ & $\begin{array}{l}\text { s31a } \\
(4)\end{array}$ & $\begin{array}{l}\text { s31b } \\
(5)\end{array}$ & $\begin{array}{l}\mathrm{s} 31 \mathrm{c} \\
(6)\end{array}$ & $\begin{array}{l}\text { s31d } \\
(7)\end{array}$ \\
\hline \multicolumn{8}{|c|}{ Panel A: 6-months follow-up results } \\
\hline Finance Training & $\begin{array}{l}-.040 \\
(0.123)\end{array}$ & $\begin{array}{c}-.025^{*} \\
(0.014)\end{array}$ & $\begin{array}{l}-.009 \\
(0.024)\end{array}$ & $\begin{array}{l}0.009 \\
(0.039)\end{array}$ & $\begin{array}{l}0.044 \\
(0.042)\end{array}$ & $\begin{array}{l}0.043 \\
(0.045)\end{array}$ & $\begin{array}{l}0.001 \\
(0.016)\end{array}$ \\
\hline Feedback Training & $\begin{array}{l}-.005 \\
(0.128)\end{array}$ & $\begin{array}{l}-.025 \\
(0.015)\end{array}$ & $\begin{array}{l}-.009 \\
(0.024)\end{array}$ & $\begin{array}{l}0.012 \\
(0.039)\end{array}$ & $\begin{array}{c}0.079^{* *} \\
(0.04)\end{array}$ & $\begin{array}{l}0.023 \\
(0.046)\end{array}$ & $\begin{array}{l}0.007 \\
(0.015)\end{array}$ \\
\hline$\beta_{1}-\beta_{2}=0(\mathrm{p} \text {-value })^{a}$ & 0.80 & 0.99 & 1.00 & 0.93 & 0.36 & 0.66 & 0.67 \\
\hline $\mathrm{R}^{2}$ & 0.02 & 0.02 & 0.01 & 0.02 & 0.03 & 0.04 & 0.00 \\
\hline Mean (SD) of & 0.00 & 0.92 & 0.96 & 0.82 & 0.79 & 0.73 & 0.98 \\
\hline control group & $(1.00)$ & $(0.28)$ & $(0.20)$ & $(0.39)$ & $(0.41)$ & $(0.44)$ & $(0.14)$ \\
\hline Observations & 460 & 460 & 460 & 460 & 460 & 460 & 460 \\
\hline control for $y_{t-1}$ & yes & yes & yes & yes & yes & yes & yes \\
\hline control for industry strata & yes & yes & yes & yes & yes & yes & yes \\
\hline \multicolumn{8}{|c|}{ Panel B: 12-months follow-up results } \\
\hline Finance Training & $\begin{array}{l}-.031 \\
(0.114)\end{array}$ & $\begin{array}{l}-.037 \\
(0.024)\end{array}$ & $\begin{array}{l}-.027 \\
(0.033)\end{array}$ & $\begin{array}{c}0.029 \\
(0.05)\end{array}$ & $\begin{array}{l}0.044 \\
(0.049)\end{array}$ & $\begin{array}{l}-.012 \\
(0.047)\end{array}$ & $\begin{array}{c}0.014 \\
(0.01)\end{array}$ \\
\hline Feedback Training & $\begin{array}{c}0.062 \\
(0.11)\end{array}$ & $\begin{array}{l}0.001 \\
(0.019)\end{array}$ & $\begin{array}{l}0.016 \\
(0.029)\end{array}$ & $\begin{array}{l}0.012 \\
(0.051)\end{array}$ & $\begin{array}{l}-.008 \\
(0.051)\end{array}$ & $\begin{array}{l}0.014 \\
(0.047)\end{array}$ & $\begin{array}{l}0.007 \\
(0.012)\end{array}$ \\
\hline April 2018 treatment & $\begin{array}{l}-.008 \\
(0.089)\end{array}$ & $\begin{array}{l}0.024 \\
(0.018)\end{array}$ & $\begin{array}{l}-.004 \\
(0.026)\end{array}$ & $\begin{array}{c}-.080^{*} \\
(0.041)\end{array}$ & $\begin{array}{l}-.011 \\
(0.041)\end{array}$ & $\begin{array}{l}0.012 \\
(0.038)\end{array}$ & $\begin{array}{l}0.004 \\
(0.008)\end{array}$ \\
\hline$\beta_{1}-\beta_{2}=0(\mathrm{p} \text {-value })^{a}$ & 0.37 & 0.11 & 0.17 & 0.72 & 0.29 & 0.57 & 0.31 \\
\hline $\mathrm{R}^{2}$ & 0.00 & 0.01 & 0.01 & 0.01 & 0.01 & 0.01 & 0.01 \\
\hline Mean (SD) of & 0.00 & 0.93 & 0.95 & 0.79 & 0.78 & 0.76 & 0.98 \\
\hline control group & $(1.00)$ & $(0.25)$ & $(0.22)$ & $(0.41)$ & $(0.42)$ & $(0.43)$ & $(0.13)$ \\
\hline Observations & 454 & 454 & 454 & 454 & 454 & 454 & 454 \\
\hline control for $y_{t-1}$ & yes & yes & yes & yes & yes & yes & yes \\
\hline control for industry strata & yes & yes & yes & yes & yes & yes & yes \\
\hline
\end{tabular}

Source: Survey on micro and small enterprises in Uganda, waves October 2017, April 2018, and October 2018, own calculations.

Notes: The table shows intention-to-treat effects on variables belonging to the financial awareness index. All outcome variables are described in Table B.2. Standard errors in parentheses. ${ }^{*} p<0.1,{ }^{* *} p<0.05,{ }^{* * *}$ $p<0.01$.

${ }^{a}$ Test for equality of estimated coefficients of being assigned to finance and feedback training. Coefficients refer to equation (1). 
Table B.7: Intention-to-Treat Effects on Financial Attitudes and Perceptions Index Components

\begin{tabular}{|c|c|c|c|c|c|c|}
\hline & $\begin{array}{c}\text { Financial Attitudes } \\
\text { and Perceptions } \\
\text { Index } \\
(1)\end{array}$ & $\overline{\mathrm{r} 6 \mathrm{a}}$ & r6b & $\overline{\mathrm{r} 6 \mathrm{f}}$ & $\overline{\mathrm{r} 8 \mathrm{~g}}$ & 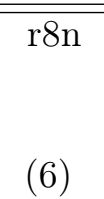 \\
\hline \multicolumn{7}{|c|}{ Panel A: 6-months follow-up results } \\
\hline Finance Training & $\begin{array}{l}-.072 \\
(0.112)\end{array}$ & $\begin{array}{l}0.107 \\
(0.131)\end{array}$ & $\begin{array}{l}0.099 \\
(0.142)\end{array}$ & $\begin{array}{l}-.124 \\
(0.144)\end{array}$ & $\begin{array}{l}-.102 \\
(0.136)\end{array}$ & $\begin{array}{l}-.232 \\
(0.157)\end{array}$ \\
\hline Feedback Training & $\begin{array}{l}-.009 \\
(0.119)\end{array}$ & $\begin{array}{l}0.135 \\
(0.131)\end{array}$ & $\begin{array}{l}-.060 \\
(0.145)\end{array}$ & $\begin{array}{l}-.132 \\
(0.144)\end{array}$ & $\begin{array}{l}0.078 \\
(0.145)\end{array}$ & $\begin{array}{l}-.093 \\
(0.157)\end{array}$ \\
\hline$\beta_{1}-\beta_{2}=0(\mathrm{p} \text {-value })^{a}$ & 0.59 & 0.83 & 0.24 & 0.96 & 0.18 & 0.37 \\
\hline $\mathrm{R}^{2}$ & 0.01 & 0.01 & 0.01 & 0.01 & 0.01 & 0.01 \\
\hline Mean (SD) of & 0.00 & 1.94 & 3.25 & 4.21 & 1.93 & 2.87 \\
\hline control group & $(1.00)$ & $(1.07)$ & $(1.37)$ & $(1.12)$ & $(1.13)$ & $(1.34)$ \\
\hline Observations & 459 & 459 & 459 & 459 & 459 & 459 \\
\hline control for $y_{t-1}$ & yes & yes & yes & yes & yes & yes \\
\hline control for industry strata & yes & yes & yes & yes & yes & yes \\
\hline \multicolumn{7}{|c|}{ Panel B: 12-months follow-up results } \\
\hline Finance Training & $\begin{array}{l}0.056 \\
(0.109)\end{array}$ & $\begin{array}{l}0.019 \\
(0.127)\end{array}$ & $\begin{array}{l}0.225 \\
(0.165)\end{array}$ & $\begin{array}{l}0.076 \\
(0.148)\end{array}$ & $\begin{array}{l}-.170 \\
(0.104)\end{array}$ & $\begin{array}{l}0.129 \\
(0.146)\end{array}$ \\
\hline Feedback Training & $\begin{array}{l}-.167 \\
(0.116)\end{array}$ & $\begin{array}{l}-.087 \\
(0.123)\end{array}$ & $\begin{array}{l}-.122 \\
(0.174)\end{array}$ & $\begin{array}{c}-.342^{* *} \\
(0.155)\end{array}$ & $\begin{array}{l}-.073 \\
(0.106)\end{array}$ & $\begin{array}{l}0.164 \\
(0.145)\end{array}$ \\
\hline April 2018 treatment & $\begin{array}{l}0.029 \\
(0.091)\end{array}$ & $\begin{array}{l}-.048 \\
(0.101)\end{array}$ & $\begin{array}{l}0.018 \\
(0.134)\end{array}$ & $\begin{array}{l}0.074 \\
(0.122)\end{array}$ & $\begin{array}{l}0.057 \\
(0.081)\end{array}$ & $\begin{array}{l}-.015 \\
(0.116)\end{array}$ \\
\hline$\beta_{1}-\beta_{2}=0(\mathrm{p} \text {-value })^{a}$ & 0.04 & 0.39 & 0.03 & 0.00 & 0.29 & 0.80 \\
\hline $\mathrm{R}^{2}$ & 0.04 & 0.04 & 0.02 & 0.04 & 0.02 & 0.04 \\
\hline $\begin{array}{l}\text { Mean (SD) of } \\
\text { control group }\end{array}$ & $\begin{array}{c}0.00 \\
(1.00)\end{array}$ & $\begin{array}{c}1.90 \\
(1.09)\end{array}$ & $\begin{array}{c}3.29 \\
(1.41)\end{array}$ & $\begin{array}{c}4.12 \\
(1.19)\end{array}$ & $\begin{array}{c}1.91 \\
(1.08)\end{array}$ & $\begin{array}{c}2.80 \\
(1.34)\end{array}$ \\
\hline Observations & 453 & 453 & 453 & 453 & 453 & 453 \\
\hline control for $y_{t-1}$ & yes & yes & yes & yes & yes & yes \\
\hline control for industry strata & yes & yes & yes & yes & yes & yes \\
\hline
\end{tabular}

Source: Survey on micro and small enterprises in Uganda, waves October 2017, April 2018, and October 2018, own calculations.

Notes: The table shows intention-to-treat effects on variables belonging to the financial attitudes and perceptions index. All outcome variables are described in Table B.2. Standard errors in parentheses. ${ }^{*} p<0.1,{ }^{* *} p<0.05,{ }^{* * *} p<0.01$.

${ }^{a}$ Test for equality of estimated coefficients of being assigned to finance and feedback training. Coefficients refer to equation (1). 
Table B.8: Intention-to-Treat Effects on Financial Planning Components and Record keeping

\begin{tabular}{|c|c|c|c|c|c|}
\hline & $\begin{array}{c}\text { Financial Planning } \\
\text { Index } \\
(1)\end{array}$ & $\begin{array}{l}\mathrm{j} 23 \mathrm{a} \\
(2) \\
\end{array}$ & $\begin{array}{l}\mathrm{j} 23 \mathrm{~b} \\
(3) \\
\end{array}$ & $\begin{array}{l}\mathrm{j} 23 \mathrm{c} \\
(4) \\
\end{array}$ & $\begin{array}{l}\mathrm{j} 6 \mathrm{a} \\
(5) \\
\end{array}$ \\
\hline \multicolumn{6}{|c|}{ Panel A: 6-months follow-up results } \\
\hline Finance Training & $\begin{array}{l}0.035 \\
(0.111)\end{array}$ & $\begin{array}{l}-.036 \\
(0.052)\end{array}$ & $\begin{array}{c}0.05 \\
(0.055)\end{array}$ & $\begin{array}{c}0.01 \\
(0.029)\end{array}$ & $\begin{array}{l}0.032 \\
(0.051)\end{array}$ \\
\hline Feedback Training & $\begin{array}{c}0.174^{*} \\
(0.097)\end{array}$ & $\begin{array}{l}-.008 \\
(0.054)\end{array}$ & $\begin{array}{l}0.056 \\
(0.057)\end{array}$ & $\begin{array}{c}0.047^{*} \\
(0.026)\end{array}$ & $\begin{array}{c}0.019 \\
(0.05)\end{array}$ \\
\hline$\beta_{1}-\beta_{2}=0(\mathrm{p} \text {-value })^{a}$ & 0.13 & 0.59 & 0.91 & 0.13 & 0.78 \\
\hline $\mathrm{R}^{2}$ & 0.02 & 0.03 & 0.02 & 0.02 & 0.19 \\
\hline Mean (SD) of & 0.00 & 0.35 & 0.58 & 0.93 & 0.34 \\
\hline control group & $(1.00)$ & $(0.48)$ & $(0.49)$ & $(0.26)$ & $(0.47)$ \\
\hline Observations & 447 & 447 & 447 & 447 & 460 \\
\hline control for $y_{t-1}$ & yes & yes & yes & yes & yes \\
\hline control for industry strata & yes & yes & yes & yes & yes \\
\hline \multicolumn{6}{|c|}{ Panel B: 12-months follow-up results } \\
\hline Finance Training & $\begin{array}{c}0.058 \\
(0.11)\end{array}$ & $\begin{array}{c}0.012 \\
(0.04)\end{array}$ & $\begin{array}{c}0.007 \\
(0.05)\end{array}$ & $\begin{array}{l}0.019 \\
(0.036)\end{array}$ & $\begin{array}{l}0.005 \\
(0.044)\end{array}$ \\
\hline Feedback Training & $\begin{array}{c}0.171^{*} \\
(0.102)\end{array}$ & $\begin{array}{l}0.026 \\
(0.041)\end{array}$ & $\begin{array}{c}0.029 \\
(0.05)\end{array}$ & $\begin{array}{c}0.055^{*} \\
(0.033)\end{array}$ & $\begin{array}{l}0.002 \\
(0.047)\end{array}$ \\
\hline April 2018 treatment & $\begin{array}{r}-0.077 \\
(0.084)\end{array}$ & $\begin{array}{c}-0.028 \\
(0.033)\end{array}$ & $\begin{array}{c}0.005 \\
(0.04)\end{array}$ & $\begin{array}{c}-0.023 \\
(0.027)\end{array}$ & $\begin{array}{l}0.018 \\
(0.038)\end{array}$ \\
\hline$\beta_{1}-\beta_{2}=0(\mathrm{p} \text {-value })^{a}$ & 0.24 & 0.72 & 0.66 & 0.25 & 0.95 \\
\hline $\mathrm{R}^{2}$ & 0.05 & 0.05 & 0.04 & 0.05 & 0.24 \\
\hline Mean (SD) of & 0.00 & 0.28 & 0.64 & 0.92 & 0.32 \\
\hline control group & $(1.00)$ & $(0.45)$ & $(0.48)$ & $(0.28)$ & $(0.47)$ \\
\hline Observations & 441 & 441 & 441 & 441 & 454 \\
\hline control for $y_{t-1}$ & yes & yes & yes & yes & yes \\
\hline control for industry strata & yes & yes & yes & yes & yes \\
\hline
\end{tabular}

Source: Survey on micro and small enterprises in Uganda, waves October 2017, April 2018, and October 2018, own calculations.

Notes: The table shows intention-to-treat effects on variables belonging to the financial planning index. The financial planning index (column (1)) comprises the variables in columns (2) - (4). All outcome variables are described in Table B.2. Standard errors in parentheses. ${ }^{*} p<0.1,{ }^{* *} p<0.05,{ }^{* * *} p<0.01$.

${ }^{a}$ Test for equality of estimated coefficients of being assigned to finance and feedback training. Coefficients refer to equation (1). 
Table B.9: Intention-to-Treat Effects on Separating Finances Index Components

\begin{tabular}{|c|c|c|c|c|c|c|c|}
\hline & $\begin{array}{l}\text { Separating Finances } \\
\text { Index } \\
(1) \\
\end{array}$ & $\begin{array}{l}j 6 c \\
(2) \\
\end{array}$ & $\begin{array}{l}\mathrm{j} 6 \mathrm{~d} \\
(3) \\
\end{array}$ & $\begin{array}{l}\mathrm{j} 6 \mathrm{e} \\
(4) \\
\end{array}$ & $\begin{array}{l}\mathrm{j} 27 \mathrm{c} \\
(5) \\
\end{array}$ & $\bar{j} 27 \mathrm{~d}$ & $\begin{array}{l}\mathrm{a} 25 \mathrm{a} \\
(7) \\
\end{array}$ \\
\hline \multicolumn{8}{|c|}{ Panel A: 6-months follow-up results } \\
\hline Finance Training & $\begin{array}{l}0.127 \\
(0.103)\end{array}$ & $\begin{array}{l}0.026 \\
(0.057)\end{array}$ & $\begin{array}{c}0.029 \\
(0.05)\end{array}$ & $\begin{array}{l}-.018 \\
(0.055)\end{array}$ & $\begin{array}{c}0.083^{*} \\
(0.049)\end{array}$ & $\begin{array}{l}0.042 \\
(0.054)\end{array}$ & $\begin{array}{l}0.055 \\
(0.056)\end{array}$ \\
\hline Feedback Training & $\begin{array}{c}-.028 \\
(0.113)\end{array}$ & $\begin{array}{l}0.002 \\
(0.058)\end{array}$ & $\begin{array}{l}0.005 \\
(0.052)\end{array}$ & $\begin{array}{l}-.087 \\
(0.054)\end{array}$ & $\begin{array}{l}0.005 \\
(0.052)\end{array}$ & $\begin{array}{l}-.003 \\
(0.055)\end{array}$ & $\begin{array}{l}0.017 \\
(0.057)\end{array}$ \\
\hline$\beta_{1}-\beta_{2}=0(\mathrm{p} \text {-value })^{a}$ & 0.13 & 0.66 & 0.63 & 0.20 & 0.11 & 0.40 & 0.50 \\
\hline $\mathrm{R}^{2}$ & 0.07 & 0.03 & 0.06 & 0.02 & 0.02 & 0.01 & 0.03 \\
\hline Mean (SD) of & 0.00 & 0.56 & 0.72 & 0.38 & 0.71 & 0.67 & 0.55 \\
\hline control group & $(1.00)$ & $(0.50)$ & $(0.45)$ & $(0.49)$ & $(0.45)$ & $(0.47)$ & $(0.50)$ \\
\hline Observations & 446 & 447 & 447 & 447 & 447 & 447 & 458 \\
\hline control for $y_{t-1}$ & yes & yes & yes & yes & yes & yes & yes \\
\hline control for industry strata & yes & yes & yes & yes & yes & yes & yes \\
\hline \multicolumn{8}{|c|}{ Panel B: 12-months follow-up results } \\
\hline Finance Training & $\begin{array}{l}0.053 \\
(0.109)\end{array}$ & $\begin{array}{l}0.075 \\
(0.054)\end{array}$ & $\begin{array}{c}0.005 \\
(0.05)\end{array}$ & $\begin{array}{l}-.016 \\
(0.052)\end{array}$ & $\begin{array}{l}0.049 \\
(0.049)\end{array}$ & $\begin{array}{c}-.051 \\
(0.05)\end{array}$ & $\begin{array}{l}0.049 \\
(0.057)\end{array}$ \\
\hline Feedback Training & $\begin{array}{l}-.013 \\
(0.113)\end{array}$ & $\begin{array}{l}-.040 \\
(0.057)\end{array}$ & $\begin{array}{l}-.048 \\
(0.053)\end{array}$ & $\begin{array}{c}0.01 \\
(0.052)\end{array}$ & $\begin{array}{l}-.007 \\
(0.052)\end{array}$ & $\begin{array}{l}0.013 \\
(0.047)\end{array}$ & $\begin{array}{l}0.057 \\
(0.058)\end{array}$ \\
\hline April 2018 treatment & $\begin{array}{l}-.085 \\
(0.089)\end{array}$ & $\begin{array}{l}-.033 \\
(0.045)\end{array}$ & $\begin{array}{l}-.069 \\
(0.042)\end{array}$ & $\begin{array}{l}-.014 \\
(0.043)\end{array}$ & $\begin{array}{l}-.021 \\
(0.041)\end{array}$ & $\begin{array}{c}-.029 \\
(0.04)\end{array}$ & $\begin{array}{l}0.027 \\
(0.047)\end{array}$ \\
\hline$\beta_{1}-\beta_{2}=0(\mathrm{p} \text {-value })^{a}$ & 0.53 & 0.04 & 0.31 & 0.61 & 0.25 & 0.19 & 0.89 \\
\hline $\mathrm{R}^{2}$ & 0.05 & 0.04 & 0.04 & 0.01 & 0.02 & 0.02 & 0.04 \\
\hline Mean $(\mathrm{SD})$ of & 0.00 & 0.64 & 0.74 & 0.28 & 0.75 & 0.79 & 0.49 \\
\hline & $(1.00)$ & $(0.48)$ & $(0.44)$ & $(0.45)$ & $(0.43)$ & $(0.41)$ & $(0.50)$ \\
\hline Observations & 440 & 441 & 441 & 441 & 441 & 441 & 452 \\
\hline control for $y_{t-}$ & yes & yes & yes & yes & yes & yes & yes \\
\hline control for industry strata & yes & yes & yes & yes & yes & yes & yes \\
\hline
\end{tabular}

Source: Survey on micro and small enterprises in Uganda, waves October 2017, April 2018, and October 2018, own calculations.

Notes: The table shows intention-to-treat effects on variables belonging to the separating finances index. All outcome variables are described in Table B.2. Standard errors in parentheses. ${ }^{*} p<0.1,{ }^{* *} p<0.05,{ }^{* * *}$ $p<0.01$.

${ }^{a}$ Test for equality of estimated coefficients of being assigned to finance and feedback training. Coefficients refer to equation (1). 
Table B.10: Intention-to-Treat Effects on Financial Reflection Index Components and Impulsiveness

\begin{tabular}{|c|c|c|c|c|c|c|}
\hline & $\begin{array}{c}\text { Financial Reflection } \\
\text { Index } \\
(1)\end{array}$ & $\begin{array}{l}\mathrm{j} 16 \mathrm{a} \\
(2)\end{array}$ & $\begin{array}{l}j 16 b \\
(3)\end{array}$ & $\begin{array}{l}16 c \\
(4) \\
\end{array}$ & $\begin{array}{l}\mathrm{j} 16 \mathrm{~d} \\
(5)\end{array}$ & $\begin{array}{l}\mathrm{r} 8 \mathrm{~s} \\
(6)\end{array}$ \\
\hline \multicolumn{7}{|c|}{ Panel A: 6-months follow-up results } \\
\hline Finance Training & $\begin{array}{l}0.014 \\
(0.112)\end{array}$ & $\begin{array}{l}0.056 \\
(0.079)\end{array}$ & $\begin{array}{l}-.027 \\
(0.133)\end{array}$ & $\begin{array}{l}-.012 \\
(0.044)\end{array}$ & $\begin{array}{c}0.01 \\
(0.061)\end{array}$ & $\begin{array}{l}0.065 \\
(0.124)\end{array}$ \\
\hline Feedback Training & $\begin{array}{c}-.003 \\
(0.12)\end{array}$ & $\begin{array}{l}0.042 \\
(0.078)\end{array}$ & $\begin{array}{l}-.050 \\
(0.131)\end{array}$ & $\begin{array}{c}-.0004 \\
(0.042)\end{array}$ & $\begin{array}{l}-.027 \\
(0.068)\end{array}$ & $\begin{array}{l}0.065 \\
(0.122)\end{array}$ \\
\hline$\beta_{1}-\beta_{2}=0(\mathrm{p} \text {-value })^{a}$ & 0.88 & 0.85 & 0.87 & 0.78 & 0.55 & 1.00 \\
\hline $\mathrm{R}^{2}$ & 0.01 & 0.01 & 0.06 & 0.00 & 0.02 & 0.01 \\
\hline Mean (SD) of & 0.00 & 3.64 & 3.11 & 3.87 & 3.80 & 4.29 \\
\hline control group & $(1.00)$ & $(0.73)$ & $(1.18)$ & $(0.39)$ & $(0.57)$ & $(1.11)$ \\
\hline Observations & 444 & 447 & 446 & 447 & 447 & 458 \\
\hline control for $y_{t-1}$ & yes & yes & yes & yes & yes & yes \\
\hline control for industry strata & yes & yes & yes & yes & yes & yes \\
\hline \multicolumn{7}{|c|}{ Panel B: 12-months follow-up results } \\
\hline Finance Training & $\begin{array}{l}0.053 \\
(0.119)\end{array}$ & $\begin{array}{l}0.027 \\
(0.063)\end{array}$ & $\begin{array}{c}-.049 \\
(0.14)\end{array}$ & $\begin{array}{l}0.032 \\
(0.052)\end{array}$ & $\begin{array}{l}0.011 \\
(0.055)\end{array}$ & $\begin{array}{l}0.071 \\
(0.125)\end{array}$ \\
\hline Feedback Training & $\begin{array}{l}-.135 \\
(0.127)\end{array}$ & $\begin{array}{l}-.061 \\
(0.068)\end{array}$ & $\begin{array}{l}-.048 \\
(0.141)\end{array}$ & $\begin{array}{l}0.036 \\
(0.051)\end{array}$ & $\begin{array}{c}0.0006 \\
(0.059)\end{array}$ & $\begin{array}{c}-.312^{* *} \\
(0.137)\end{array}$ \\
\hline April 2018 treatment & $\begin{array}{l}0.009 \\
(0.102)\end{array}$ & $\begin{array}{l}-.012 \\
(0.053)\end{array}$ & $\begin{array}{l}0.116 \\
(0.114)\end{array}$ & $\begin{array}{l}-.012 \\
(0.042)\end{array}$ & $\begin{array}{l}-.009 \\
(0.047)\end{array}$ & $\begin{array}{l}-.004 \\
(0.108)\end{array}$ \\
\hline$\beta_{1}-\beta_{2}=0(\mathrm{p} \text {-value })^{a}$ & 0.14 & 0.18 & 0.99 & 0.94 & 0.85 & 0.00 \\
\hline $\mathrm{R}^{2}$ & 0.01 & 0.02 & 0.02 & 0.01 & 0.01 & 0.03 \\
\hline Mean (SD) of & 0.00 & 3.75 & 3.09 & 3.77 & 3.77 & 4.19 \\
\hline & $(1.00)$ & $(0.56)$ & $(1.17)$ & $(0.45)$ & $(0.48)$ & $(1.09)$ \\
\hline Observations & 438 & 441 & 440 & 441 & 441 & 452 \\
\hline control for $y_{t}$ & yes & yes & yes & yes & yes & yes \\
\hline control for industry strata & yes & yes & yes & yes & yes & yes \\
\hline
\end{tabular}

Source: Survey on micro and small enterprises in Uganda, waves October 2017, April 2018, and October 2018, own calculations.

Notes: The table shows intention-to-treat effects on variables belonging to the financial reflection index. The financial reflection index (column (1)) comprises the variables in columns (2) - (5). All outcome variables are described in Table B.2. Standard errors in parentheses. ${ }^{*} p<0.1,{ }^{* *} p<0.05$, *** $p<0.01$.

${ }^{a}$ Test for equality of estimated coefficients of being assigned to finance and feedback training. Coefficients refer to equation (1). 